(C) THE BALTIC SCIENTIFIC JOURNALS

\title{
SOCIOWORLD
}

SOCIAL RESEARCH \& BEHAVIORAL SCIENCES

REFEREED \& REVIEWED JOURNAL

\section{VOLUME 01 ISSUE 012020}

http://sc-media.org/
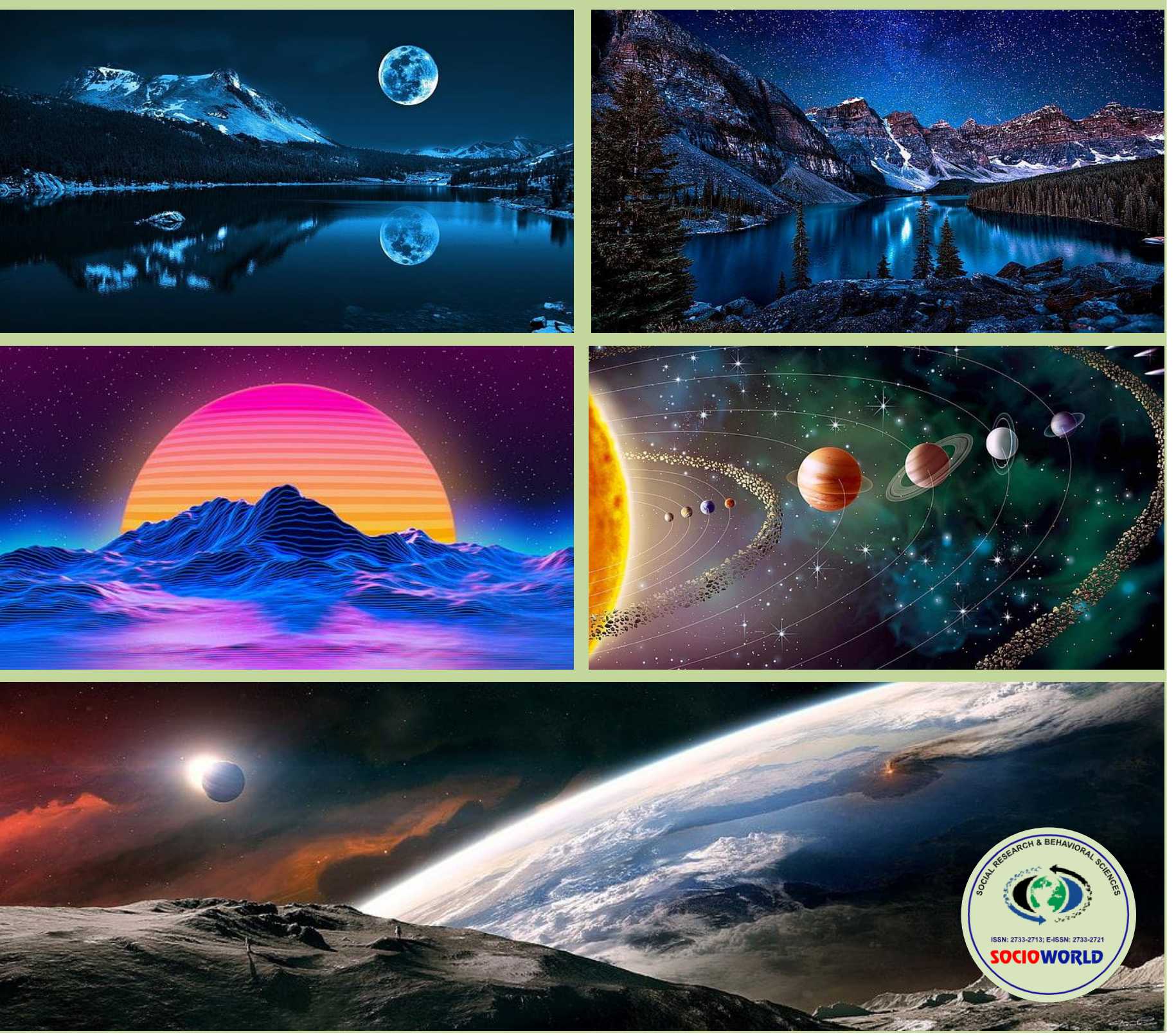


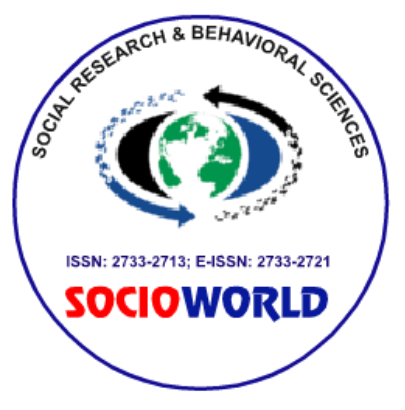

(C) THE BALTIC SCIENTIFIC JOURNALS

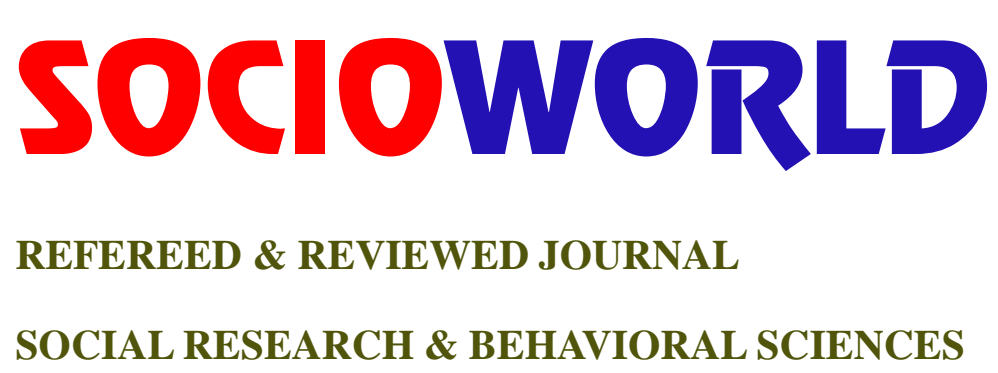

VOLUME 01 ISSUE 012020

http://sc-media.org/ 
CPublisher: LEPL, Sokhumi State University. R/C 405282260.

Rector: Zurab Khonelidze, Professor, Doctor of Political Sciences, Editorial Board Member.

Editors-in-chief: Zurab Khonelidze, Professor, Doctor of Political Sciences, Editorial Board Member.

Deputy of Editor-in chief: Davit Jalagonia, Professor, PhD in Economics, Professor, Sokhumi State University. Registered address: 61, Politkovskaya street. 0186 Tbilisi, Georgia.

Technical and reviewer team manager: Larisa Takalandze, Professor, PhD in Economics, Head of Management Module.

CPublisher: Chernihiv Polytechnic National University. R/C 054607925261

Rector: Oleg Novomlynets, Professor, Doctor in Technical Sciences.

Technical and reviewer team manager: Olha Rudenko, Professor, Doctor of Science in Public Administration. Editors-in-chief: Peter Jakubek, Quaestor of DTI University. Doctor in Economic Science.

Associate Professor. Dubnica and Vahom. (Slovakia)

Deputy of Editor-in chief: Aleksander Kuczabski, Institute of Geography of Uniwersytet Gdański, Department of Regional Development Geography, Doctor in Public Administration Science.

Associate Professor.

Registered address: 95, Shevchenko street, 14035, Chernihiv, Ukraine.

CPublisher: All Ukrainian Institute of Eurasian Research And Eastern Science. RIC 39783993

Registered address: 3B, Petra Hryhorenka Avenue, office 111, Kyiv, 02068, Ukraine

Director and Founder: Olha Rudenko, Professor, Doctor of Science in Public Administration.

CPublisher: NGO International Center for Research, Education \& Training.

MTÜ Rahvusvaheline Teadus-, Haridus- ja Koolituskeskus.

Management Board Member: Seyfulla Isayev.

CEditorial office: Narva mnt 5, 10117 Tallinn, Estonia.

(C) Typography: NGO International Center for Research, Education \& Training. R/C 80550594

Registered address: Narva mnt 5, 10117 Tallinn, Estonia.

Telephones: +994 5524170 12; +994518648894;

E-mail: gulustanbssjar@gmaill.com, sc.mediagroup2017@gmail.com,

Website: http://sc-media.org/

ISSN: 2733-2713; E-ISSN: 2733-2721; DOI: 10.36962/SWD

SOCIOWORLD-SOCIAL RESEARCH \& BEHAVIORAL SCIENCES

http://sc-media.org/swd/

CLLC CPNU, NGO AUIERES, NGO SSU, MTÜ ICRET. The Baltic Scientific Journals. All rights reserved. Reproduction, store in a retrieval system, or transmitted in any form, electronic of any publishing of the journal permitted only with the agreement of the publishers. The editorial board does not bear any responsibility for the contents of advertisements and papers. The editorial board's views can differ from the author's opinion. The journal published and issued by The Southern Caucasus Media Group. 
TABLE OF CONTENTS

Sergey Grivko

PUBLIC INFORMATION POLICY FOR THE DEVELOPMENT OF CLUSTER STRUCTURES IN THE

ECONOMY OF UKRAINE

Pavlo Halimon

PUBLIC REGULATION OF LAND RELATIONS IN UKRAINE

\section{Yevheniy Kodis}

EFFECTIVENESS OF THE PUBLIC ADMINISTRATION SYSTEM BASED ON THE IMPLEMENTATION OF

THE EU EASTERN PARTNERSHIP PROGRAM IN UKRAINE

\section{Anatoliy Kutsevol}

INTERACTION OF STATE AUTHORITIES OF UKRAINE WITH EUROPEAN DEVELOPMENT

PARTNERS: PROBLEMS AND DIRECTIONS OF THEIR SETTLEMENT

Mykhailo Vasyliev

CUSTOMS VALUE CALCULATION PROBLEMS AMID FOREIGN TRADE ACCOUNTING,

TAXATION HARMONIZATION AND USING INNOVATIVE TECHNOLOGIES

Nataliia Holovchenko, Yevhen Holovchenko

CREATURE OF EFFECTIVE SYSTEMS OF ECONOMIC CONTROL IN HOUSING AND COMMUNAL SERVICES IN CONDITIONS OF TRANSFORMATION OF GENERAL MANAGEMENT PRINCIPLES IN INDUSTRY

Halyna Kuzmenko, Nataliia Shalimova, Alla Lysenko

INFORMATION SUPPORTING SYSTEM ABOUT TAX CAPACITY OF A COMPANY AND ITS

EFFICIENCY: PRINCIPLES OF FORMATION AND EVALUATION

Larisa Takalandze, Eliso Lanchava

CREATIVE THINKING, INNOVATION AND IDEA GENERATION IN MODERN MANAGEMENT

Lasha Takalandze

MY PERSONAL LEADERSHIP EXPERIENCE

Olha Rudenko, Tetiana Shestakovska

MODERNIZATION OF THE PUBLIC ADMINISTRATION SYSTEM IN THE CONDITIONS OF

DECENTRALIZATION OF POWER

Maksym Zhytar, Julia Ananieva

ANTI-CRISIS FINANCIAL REGULATION OF THE BANKING SYSTEM: DOMESTIC REALITIES AND

FOREIGN EXPERIENCE

Irma Baratashvili

FOR A PROPER UNDERSTANDING OF THE ESSENCE AND INTRINSICALLY OF CREATIVE

MANAGEMENT 


\title{
PUBLIC INFORMATION POLICY FOR THE DEVELOPMENT OF CLUSTER STRUCTURES IN THE ECONOMY OF UKRAINE
}

\author{
Sergey Grivko \\ Applicant of the National University "Chernihiv Polytechnic". Ukraine. http://orcid.org/0000-0002-8801-0363 \\ Email: grivkos@gmail.com
}

\begin{abstract}
The peculiarities of public administration of the organizational process of the system for ensuring the development of cluster structures in the economy have been determined. The tasks of the public policy in the system of information support for the development of an innovation cluster and the use of corresponding information potential and intellectual capital have been identified. The problems and possible socio-economic conflicts in the system of implementation of the public policy on ensuring the development of the innovation cluster have been systematized. The conceptual approach to the process content of the public policy on information support for innovation clusters of the economy has been presented. The algorithm for implementing the public policy on information support for the development of innovation clusters has been proposed. The structure of the mechanism of public administration on the use of information resources for the development of innovation clusters in the economy of Ukraine has been proposed. It has been stated that the development and implementation of the public information policy for the development of clusters are based on the conceptual principles of their functioning, goals, and objectives, which are focused on the direct formation and implementation of the information potential of clustering participants.

Key words: public policy, information support, development, innovation clusters, mechanism, economy, public administration, clustering, development.

\section{INTRODUCTION}

To ensure the effective operation of innovation clusters in the economy, it is necessary to study in detail all aspects of the problem related to the development of network structures; determine their solutions and develop an organizational and economic mechanism for their information support, which will increase the effectiveness of production processes in the industry and the country as a whole. For the development of clusters, it is necessary to develop the stages of formation and activity of innovative cluster structures and their regulation by the state, to conduct a more detailed analysis of the theory and practice of global and national successful network structures. So far, the main mechanisms of implementation of cluster theory in the context of world developments for further theoretical understanding and practical use in Ukraine are insufficiently studied. The main purpose is to study issues related to the development of strategic directions for the implementation of public information policy for the development of innovation clusters in the economy of Ukraine.
\end{abstract}

Analysis of recent research and publications. Cluster theory has always been and is in the center of attention of domestic and foreign scientists, such as S. Mytsiuk, S. Sokolenko, H. Khasaiev, M. Voinarenko, M. Entrait, A. Marshal, and many others. Domestic researchers develop solutions to the problems of adaptation or creation of cluster structures that will be successful in the economy of Ukraine. At the same time, little attention is paid to the adaptation of clusters to the conditions and features of the Ukrainian present, overcoming the formalization of work, a comprehensive approach to the creation of network structures.

Results of the research. Integration changes, which form the modern landmark of the European movement of Ukraine and new formats of more open interaction with world markets, first of all, provide for the formation of a modernized vision of mechanisms for implementing the public policy to ensure sustainable economic development of regions and the country as a whole. Current trends in the complication of competitive relations, corresponding integration and disintegration processes in the national economy, disruption of established economic relations with the outside world form negative aspects of economic development, and significantly complicate socio-economic relations with external stakeholders.

Ukrainian scholars are actively discussing urgent issues related to the development of information potential of the regional economy, which implies a harmonious relationship and the presence of similarities, especially concerning the level of communication with different markets in the regions and especially with the information market infrastructure. It is such processes that require the development and implementation of effective public policy measures for integrated development, which should be reflected in the relevant regional strategies, various program and target documents, and strategic priorities of public information policy. Thus, the specialization of regions (agricultural, transport, industrial, 
tourism, etc.), and their sectoral structure require the development of appropriate guidance to provide all stakeholders with timely and accurate information. Accordingly, the changes that occur in the sectoral structure require a timely response and structural changes in the relevant areas and proposals for information support of the economy of the regions. In turn, this plays a significant role in the information reproduction of the economy of the regions. Thus, the formation of a specialized information and coordination center will contribute not only to the timely use of the necessary information, but also to form strategic measures to implement the public policy regulating the quality of goods and services. The formation and development of the information market at the level of regions, its functioning, first of all, will allow to neutralize corresponding regional disproportions, and eliminate the corresponding facts concerning information asymmetry [1-2].

It is necessary to understand such an issue as the quality of provided information technologies, which are involved and stimulate the promotion of innovative cluster initiatives and integration into the relevant processes of modern public policy. In the studied plane, there are certain features and principles of their use. We will present the most important features of state regulation of the process of organizing the information support system: presentation of the technological purpose and current tasks; development of all possible components and operations in the system of procedural and technological support; structuring the processes in accordance with the goals, objectives (road maps, tactical and strategic plans of the state); conducting non-rigid control of information, minimization of competitive tension; promoting an increase in information risks and other conflicting issues, primarily related to the socio-economic interests of clustering stakeholders. Therefore, the information technologies that need to be developed and implemented somehow form the information potential of cluster formations. They must meet the relevant management standards [3]: possibility of unification and standardization; structure in accordance with the tasks; consideration of the content of all components (which meet the needs of innovative development of stakeholders in the clustering process); adherence to the logic of using existing technologies; optimization of large amounts of information; compliance with international standards of information progress; complexity and a unified approach to the implementation of tools for processing information resources; sustainability of use, high-quality software and its adaptability to other components of the information movement management process; constant self-updating themselves and clear innovative properties.

It is this sequence and essential content, of course, that is not obligatory, providing targeted movement, elaboration of existing potential, and systematic interaction in the context of the development of theory and practice. The general purpose of the public policy on information support for the effective activity of innovation cluster is accumulation, integration, and use of the corresponding information resources with a certain target orientation on more expanded reproduction of social and economic, business, and innovative activity. The tasks of public policy in the system of information support for the development of the innovation cluster and the use of the relevant available information potential and intellectual capital include [4-5]: formation of a comprehensive database of information resources of relevant regions based on modern technologies - Internet resources, libraries, regional enterprises, etc.; formation of an information base on the innovation potential of the regions in the form of relevant management developments, various technical projects; promotion of the projects in the field of commercialization of innovations; development of the system of services in the field of consulting on the use of the relevant information base; creation of scientific principles (theoreticalmethodological and practical) for the development of information support and its state support for further commercialization of scientific developments; assessment of the demand of regional economic entities, authorities, the population in general for the relevant information resources (identification of qualitative and quantitative parameters); formation and use of a system of indicators (technical, environmental and economic) that should assess the state of development of regions and its economic entities; transition to automated servicing of all cluster members, the entire population of the region, authorities with accessible and relevant information resources; modernization of information technologies for information processing and use of relevant resources; dissemination of technologies of informatization and automation of information service of all population of the region.

As a result of the research, problems and possible socio-economic conflicts in the system of implementation of the public policy on information support of the innovation cluster have been identified as follows:

1. Trade secret in the business information system and its non-violation in order to ensure information transparency of all cluster members.

2. Problems with organization of management system and implementation of public information support policy in connection with the separation of the internal sphere of the process of formation of necessary information resources from the external one, which leads to difficulties in strategy formation, creation of perspective development directions, etc. To solve this problem, various techniques are used, such as the formation of multilevel goals, identification of internal and external factors in the process of SWOT-analysis of the existing situation [6-7].

3. Problems with formation of pricing policy on relevant information resources from the standpoint of socio-economic interests of cluster members. The conceptual approach to the process content of the public policy on information support for an innovation cluster is presented in Figure 1.

Development and implementation of the public policy on information support for clusters are based on conceptual bases of the development of clusters, their purposes, and those tasks which are focused on the formation and implementation of information potential of the participants of clustering. Therefore, the formation of a single integrated information potential of clusters can already be considered as a cluster initiative [8]. 
Regarding the integrated information potential of clusters of the economy, it is necessary to have a clearly regulated model of public policy on the formation and use of such information potential. It is possible to use the following models:

1. Open model provides access to information resources of absolutely all participants and stakeholders of the cluster. In this case, access is free (however, the costs of maintaining and expanding the relevant databases are borne equally by all members of the cluster). All external entities wishing to obtain relevant information must enter into commercial relations and pay their share of the fee for access and use of such information resources. To service this type of model, it is advisable to use so-called cloud technologies. An important point for the use of cloud services is the use of a wide range of devices forming a two-way connection between the cloud and the client.

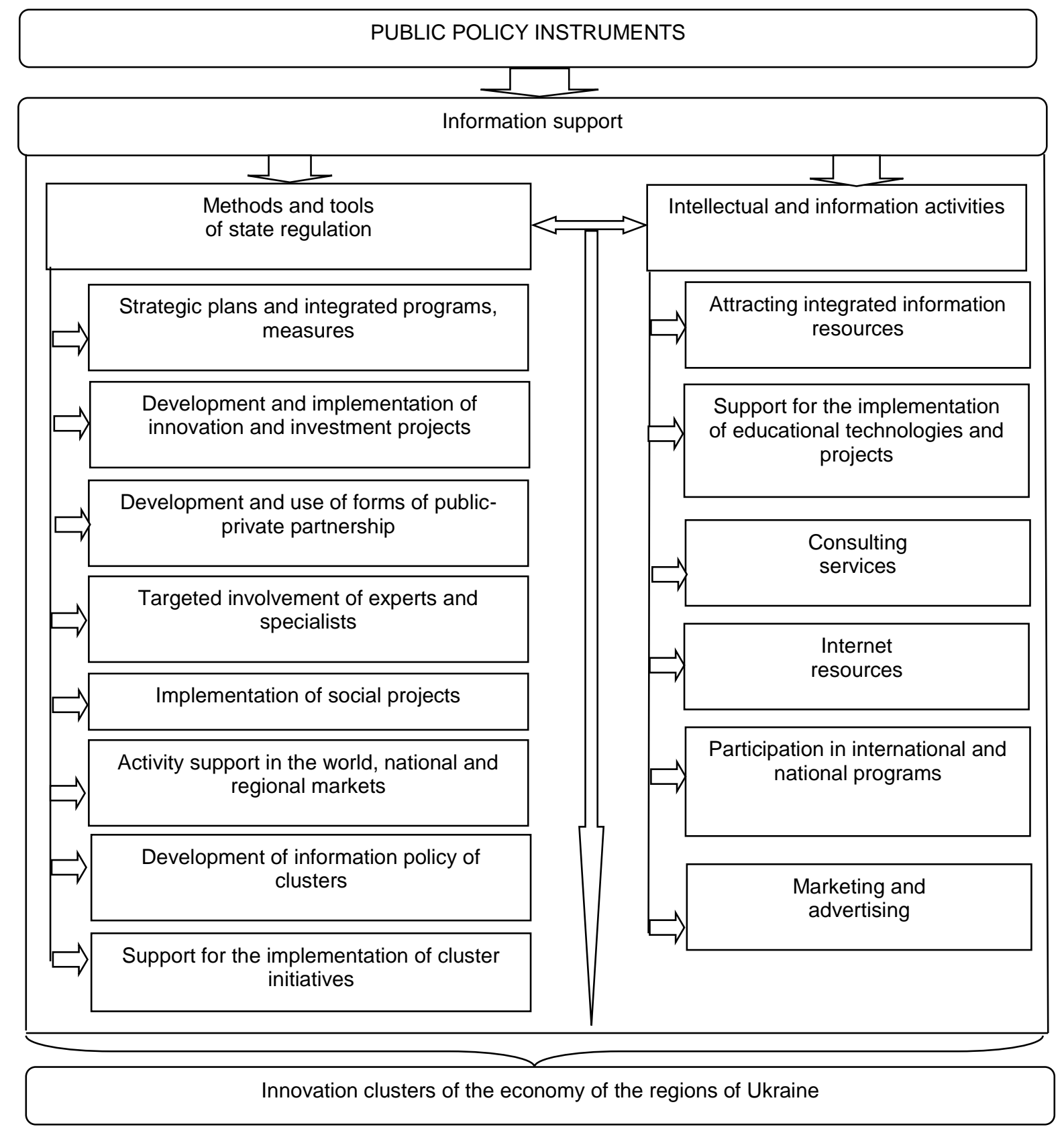

Figure 1. Conceptual approach to the process content of the public policy on information support for innovation clusters of the economy of Ukraine*

* Source: developed by the authors 
2. Semi-open model assumes that access to such information resources is limited to certain members of the cluster. Accordingly, the range of free access is limited by the terms of the contractual relations of the cluster members.

3. Semi-closed model means that access to information resources has a more clearly defined and limited range of cluster members with special access conditions.

4. Closed model assumes that for external users the relevant information resources are closed and includes complete confidentiality of documentation and information resources.

Regardless of the characteristics of the presented models of public policy on the implementation of information relations, we propose to use a clear algorithm for implementing the public policy measures on information support for the development of innovation clusters of regional economies (Figure 2).

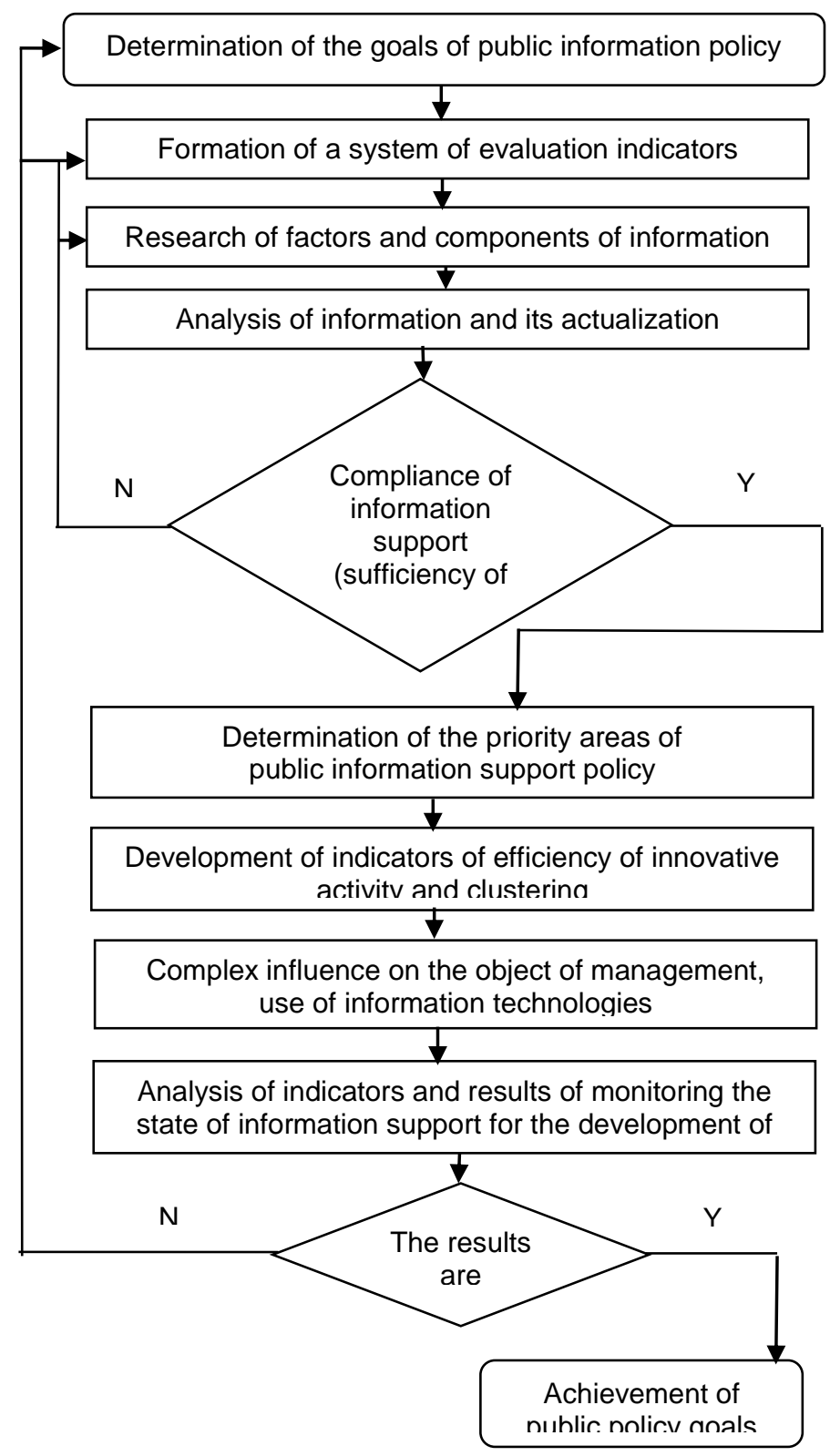

Figure 2. Algorithm for implementing the public policy on information support for the development of innovation clusters*

* Source: developed by the authors 
The algorithm presented provides an opportunity to take into account various changes in a timely manner, to develop specific scientific and methodological support for assessing information resources, organizing expert assessments in independent testing, system diagnostics, and other procedures on information support for regional economies.

The main requirements of high-quality information support in the context of ensuring the development of the innovation cluster from the standpoint of technical-technological and socio-economic opportunities, needs, interests of stakeholders of the economic system of regions in improving resources include the following:

1. Complexity in methodology, scientific-methodical, and technological formation of relevant databases.

2. A unified systematic approach to the management of relevant information resources in the context of the formation of databases, information processing, accumulation and expansion of existing capacity, compliance with security standards, and other pressing issues.

3. A single approach to the use of management technologies, the use of certain information resources on software, certain access to cloud technologies, etc.

4. Collective control and targeted use.

5. Comprehensive approaches to reengineering in order to ensure changes in business processes and disclosure of information resources, forecasting the demand for information for a particular region, growth of potential customers.

6. Organization of accounting and evaluation of collective information resources as an important process of ensuring the development of the entire cluster system.

7. Presentation of common standards on the observance of information culture as a promising future in the context of the development of the information economy of Ukraine.

To form and implement an effective public policy on information support for the development of innovation clusters, it is necessary to develop a management mechanism and use effective regulatory tools (Fig. 3).

The mechanism proposed is quite dynamic and can be modernized by adding new components, effective target tools; it can interpret the socio-economic needs and interests of participants and stakeholders of the cluster, intensify the principles of regulation, specific methods, and functions of information activities.

Thus, the experience of clustering at the world community level provides some opportunities to determine the fundamental characteristics and differences for cluster formations from usual classical models of the organization of economic activity.

That is, the life cycle for a cluster initiative is not sufficiently influential on the performance of cluster participants. Therefore, the features of viability for the cluster initiative are in fact infinite due to the integration - that is, information, different management motives, areas of interest of stakeholders.

The movement of cluster formation itself is a unique process in information activity. The main element in clustering for each participant in such a specific process, we propose to consider the accumulation of experience and the formation of appropriate information potential as a systemic phenomenon of the relevant integrated activities. That is, the process of clustering in the economy of the regions is positive and driving.

Thus, regional economic systems in the process of development of innovation clusters get a positive result for the reproduction of the socio-economic environment within the existing and expanded information potential, complicating and saturating its elements. Under the information potential, it has been proposed to consider a complex phenomenon in the management environment, which has its own structure, relevant laws, and patterns of development, and dictates its vector for the development of information culture. 


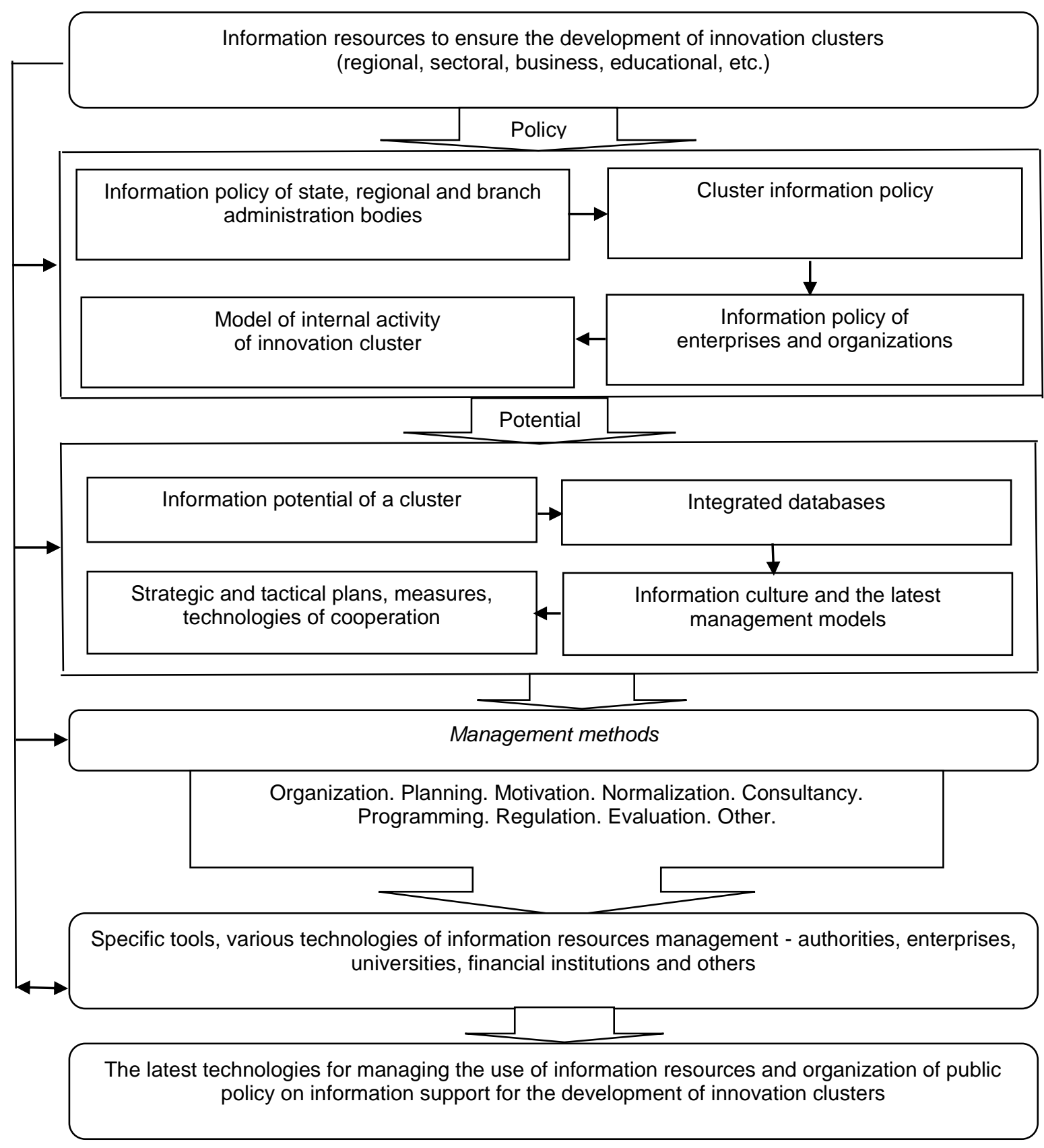

Figure 3. Mechanism of public administration on the use of information resources for the development of innovation clusters in the economy of Ukraine ${ }^{\star}$

* Source: developed by the authors

\section{CONCLUSIONS}

Scientific and methodological approaches to the formation and implementation of public policy on information support and appropriate organizational and institutional support for the development of innovation cluster on the basis of determining appropriate models of information support (closed, open, semi-closed, and semi-open types with characteristics of information activities and communication connections), goals, objectives, tasks, and principles of the public administration of information support for the development of innovation clusters have been formed. It helped to identify the key conflicts in the information support system for innovation cluster and form an algorithm for implementing public policy on 
information support for the development of an innovation cluster and a mechanism for implementing state tools on the use of information resources of a relevant innovation cluster. The experience of clustering at the world community level provides certain opportunities to determine the basic characteristics and differences for cluster formations from the usual classical models of economic activity. Positive results of the public policy for ensuring the development of innovation clusters are the solution of a set of issues, in particular, it: determines the presence of possible socio-economic and environmental conflicts, problems, or prospects for development; uses integration information and management resources; allows forming a new expanded, integrated information potential by combining information resources. Therefore, regional economic systems in the process of the development of innovation clusters get a positive result for the reproduction of the socio-economic environment within the existing and expanded information potential, complicating, and saturating its elements. Thus, the mechanism of information potential management provides effective, purposeful involvement of relevant information resources. World experience emphasizes this view in the context of sustainable development of innovative clusters on the basis of universities, relevant research institutions, because they are information centers for regions, the country, or industries.

\section{REFERENCES}

1. Porter, M. (2008), Competitive strategy: methodology for analyzing industries and competitors, translated from Eng, Moscow, Russia, 453 p. [in Russia]

2. Marshall, A. (1990), Principles of Economics: An introductory volume, UK Macmillan, London.Hubeni, Yu. (1998), "Agricultural Market Regulation in Agriculture of the Czech Republic", Economic AIC, no. 2, pp. 72-76. [in United Kingdom]

3. Feldman, V.P. and Audresch, D.B. (1999), Innovation in Gities: Science based Dvesity, Specialization and Localized Competion, European Economic Review, no. 43, pp. 31-39. [in United Kingdom]

4. Salukvadze, I.M. (2008), Cluster formation of the regional economy, Rehionalnyi zbirnyk naukovykh prats z ekonomiky «Prometei», no. 3, pp. 39-41. [in Ukrainian]

5. Sokolenko, S.I. (2006), The strategy of Ukraine's economic competitiveness based integration systems clusters, Izd LLC "Ribest", Sevastopol, Ukraine, 38 p. [in Ukrainian]

6. Rudenko O., Dyvnych H. (2019) Conceptual comprehension of strategies for ensuring social stability in the interests of the citizens and the safety of the state. Fundamental and Applied Researches in Practice of Leading Scientific Schools, 31(1), pp.173-177. [in Canada]

7. Sabluk, P.T. and Kropyvko, M.F. (2010), Clustering as a mechanism to increase competitiveness and social focus of Agricultural Economics, Ekonomika APK, no. 1, pp. 4-10. [in Ukrainian]

8. Rudenko O., Zhytar M., Ananieva Yu. (2020) Peculiarities of applying the methodology of evaluation of the financial architecture of the national economy. Association agreement: driving integrational changes: monograph. Accent Graphics Communications \& Publishing, 2020. Vol. III. pp. 200-209. [in Türkey] 


\title{
PUBLIC REGULATION OF LAND RELATIONS IN UKRAINE
}

\author{
Pavlo Halimon
}

Applicant of the National University "Chernihiv Polytechnic", Ukraine. http://orcid.org/0000-0003-3259-597X.

Email: super.halimon@ukr.net

\begin{abstract}
The article presents the features of public regulation of land relations in Ukraine. It has been established that the public policy on land relations in Ukraine is at the stage of formation and currently does not meet the world criteria and requirements for proper management of land relations. It has been proved that in order to improve the legal framework of public regulation of land relations, the state must create favorable conditions for effective land reform, which will primarily improve the legal mechanism and form a new strategic public management through initiative changes in the legislative sphere of land relations. The applied tools of the legal mechanism for public regulation of land relations in Ukraine have been presented. The main shortcomings of the legal mechanism for public regulation of land relations in Ukraine have been highlighted. It has been offered the ways of improvement of the legal mechanism for public regulation of land relations, which will promote the formation of integral public policy in the field of land relations. An adapted structural model of the legal mechanism for public regulation of land relations has been presented.
\end{abstract}

Key words: public policy, land resources, land relations, legal mechanism, public regulation.

\section{INTRODUCTION}

The current public policy of land relations in Ukraine is an important factor in ensuring the effectiveness of various sociopolitical and economic reforms in Ukraine, which affects the quality of human culture and social order in the country, ensuring the rational development of its natural resource potential. At present, Ukraine lacks a systemic and functional approach to reforming land relations, and the regulatory framework in this area is fragmented and unbalanced. Domestic legislation in the field of legal regulation of land relations is inconsistent and does not take into account the urgent needs of society in a decentralized environment. It is the imperfection of the mechanism for public regulation of land relations and the lack of a strategic plan for its reform have exacerbated natural resource problems that are an obstacle for the innovative development of the agricultural sector and the state and its regions, in particular. The solution to such problems is usually constrained by the inadequate scientific and methodological basis for improving the mechanism for implementation of the public policy on regulation of land relations in the conditions of decentralization.

Analysis of recent research and publications. A significant contribution to the development of scientific and methodological provisions and practical aspects on land relations regulation and land market formation is presented in the works of such domestic scientists as O. Borodina, L. Polishchuk, A. Tretiak, M. Fedorov, O. Chaplyhin, T. Shestakovska, M. Shchuryk, and others. However, the issues concerning the effectiveness of public regulation, the adequacy of agricultural policy instruments, and regulatory support for the functioning of the land market remain debatable. In addition, the current stage of reforming land relations is in a period of decentralization.

Research results. At present, land reform in Ukraine has accumulated system-universal characteristics, and the main directions of implementation of current public policy on the regulation of land relations, which include updating the legal framework and means of reforming land relations in the conditions of decentralization. This requires the development and formation of the adequate mechanism for public regulatory policy correspond to real socio-economic processes in the country. It should include a set of legal, economic, technical, technological, and organizational measures to ensure the transformation of land relations [1-2].

We believe that the imperfection of the legal mechanism for public regulation of land relations can be attributed to the inefficiency and imperfection of legislation in the field of land management. First of all, in Ukraine there is no integral and effective system of land legislation, some legal norms are outdated and contradictory. The updated Land Code of Ukraine today is not an effective legal basis for reforming land relations. Many current land legal rules are outdated and contradictory.

Thus, the current state of legislative regulation of land relations requires a generalized strategy of action, namely: approval at the highest level of the concept of public regulation of these relations in the long run. One of such concepts was approved for the period up to 2020 under the title: "State Targeted Program for the Development of Land Relations for the Period until 2020", which is based on the program-target method of budget funds management.

According to the author, to improve the legal framework of public regulation of land relations, the state should create favorable conditions for effective land reform, which will primarily improve the legal mechanism and the formation of a new strategic public management through initiative changes in the legislative sphere of land relations. 
It should be noted that the primary basis for the legal mechanism for public regulation of land relations in Ukraine is the legislative base that determines the relations of the subjects of land relations and the corresponding organizational structures of land use management in Ukraine. It is the state through its legal framework pursues a policy aimed at increasing the economic independence of the territories and gives local governments the opportunity to independently dispose of the lands of territorial communities [3].

At the same time, we confirm that the legal and regulatory framework allows controlling the activities of local governments in the field of land regulation by mandatory approval of land management documentation by state executive authorities. Therefore, we confirm the following: instruments of legal regulation are mandatory and provide a specific way of legal influence on the behavior of land relations concerning consolidation of land ownership, its content and methods of implementation, ensuring rational land use, protection, and reproduction of land resources, environmental protection, protection of environmental rights and interests of the society and business entities. In addition, the toolkit of legal regulation (Table 1) include environmental and resource laws and regulations.

Table 1

Applied toolkit of the public regulation of land relations in Ukraine*

\begin{tabular}{|l|l|}
\hline Legal regulatory instruments & Permitting instruments \\
\hline - development and adoption of natural resource and & - licensing of economic activities related to \\
environmental legislation; & environmental impact; \\
- general and sectoral/industrial strategies for sustainable & - licensing of economic activities related to \\
development, roadmaps agreed with the concept of & environmental audit, control, and monitoring; \\
building a new regional map (required by the Association & - permits for production and economic activities; \\
Agreement); & - certification of land surveying engineers; \\
- concepts, strategies, state target programs for the & - permits for waste disposal, warehousing, and \\
development of land relations; & storage; \\
- plans and projects for the use, protection, and & - town-planning procedures; \\
reproduction of land resources; & - environmental impact assessment; \\
- resolutions, decrees, regulations, instructions, letters, & - state ecological expertise; \\
explanations on the use, protection, and reproduction of & - Environmental Impact Assessment (EIA). \\
land resources; & \\
- consideration of environmental aspects of land use in & \\
statistical reporting. & \\
\hline
\end{tabular}

* Source: defined and summarized by the author based on [4-5].

It should be noted that the instruments of legal regulation designed to ensure the effective implementation of legal norms in the process of public policy on the regulation of land relations. Also, based on the results of the development of this toolkit, the legal norms of administrative influence of all elements of the structure of the legal mechanism are established, which determine the goals, objectives, principles of the mechanism and regulate relations arising in the land sphere [6]. Thus, the leading purpose of the legal mechanism for public regulation of land relations is the formation and consolidation of the right of every person and the society as a whole to a safe environment, determination of the right of citizens and legal entities to private ownership of land and other natural resources [7].

We believe that the main disadvantage of the studied mechanism in Ukraine is the public regulation of the activities of regulatory authorities at the level of relevant bylaws. In our opinion, insufficient attention to solving legal problems raises a number of problems of organizational and personnel support of land relations management.

The principles of the state regulatory policy in the land sphere are the following [4-5]:

- $\quad$ substantiation of the need for public regulation of land relations to prevent imbalances in the public sphere;

- balance of interests - formation of the balance of the interests of society, individual citizens, businesses, and the state by regulatory factors;

- relevance - compliance of mechanisms and methods of regulation with the current social needs and relations, considering possible risks and facts of development and impact;

- $\quad$ positive results - positive impact of regulatory actions of the state, with the receipt of economic effects at a low cost of resources, the high payback of government spending;

- $\quad$ forecasts and expected prospects - consistency, stability of regulatory policy, systematic development in a particular social direction; planned course;

- consideration of public interests, openness, and functionality of public control at all stages of implementation of regulatory norms of the state.

In accordance with social requirements, the main objectives of public policy in the field of circulation of agricultural land should be the following: strengthening the food security of the country; protection of the legitimate interests of landowners and users; improving the level of employment of the rural population and the demographic situation in rural areas; ensuring sustainable, rational, and efficient land use; ensuring sustainable development of rural communities; increasing 
the capitalization and liquidity of land as an economic asset; ensuring a fair price for land and the level of payment for land use; prevention of avoidance of fiscal losses and application of shadow schemes of tax evasion, raider schemes of land seizure, use of fictitious persons in case of acquisition of the right of ownership and use of land; introduction of mechanisms to prevent speculative operations and monopolization of agricultural land.

Thus, we can conclude that in the field of land use there is no effective control over the implementation of legislation. For example, the law stipulates that the costs associated with the delimitation of state and private lands are borne by the relevant (state and local) budgets. However, sometimes this type of work is not planned to be financed from the appropriate budget levels. Thus, we have identified the main shortcomings of the legal mechanism for public regulation of land relations as follows: replacement of economic market mechanisms by administrative ones, that significantly reduces the efficiency of regulation and control of land relations; inconsistency of state and regional programs and action plans in the fields of industry, energy, urban planning, etc. with land reform plans, land use norms and environmental standards; lack of a comprehensive public land policy and a comprehensive action program in the field of land relations; concentration of public control over land resources and land use in the authorities (state committees on land resources); directing public financial control to respond to abuses in the field of land use, but not to prevent them; lack of system, completeness of determining the legal status and competence of the subjects of control, the presence of contradictions and duplication of functions; inconsistency of the main directions of interaction of legal acts of public financial control with acts in the field of land relations, which will not contribute to a clear distinction between external and internal control; irregular publication and incompleteness of reports on inspections of land management bodies; fragmentary prevention of financial violations, ineffectiveness of the system of liability for financial violations; lack of clear legislative consolidation of the procedure of public financial control, which negatively affects the independence of public financial control during control measures [8].

These shortcomings necessitate the development of legislative mechanisms for regulating and controlling land relations. The consequences of the imperfection of the legal mechanism for public regulation of land relations are the following: 1) shadow cash flows and the shadowland market; 2) corruption; 3) abuse of power and neglect of public interests; 4) lobbying the interests of big business.

The reasons for ineffective public regulation of land relations are logically related to inefficient administrative management system and complex hierarchical relationships, spontaneous changes in land management bodies, which leads to abuse and irresponsibility of heads of institutions and staff. In addition, the legal framework in the field of public financial control has a fiscal focus, devoid of incentives to improve budgetary discipline.

Despite the fact that a large number of authorities are concentrated in land resources management, they are unable to perform the tasks assigned to them in accordance with current legislation. At the same time, the inflow of budget funds for land reform is high, but well-established systems of money laundering undermine the budget, agrarian reform, and the economy as a whole.

In order to eliminate the main shortcomings of the legislation, measures for improving the legal mechanism for public regulation of land relations have been proposed, which will promote the formation of a holistic public policy in the field of land relations (Figure 1).

The measures proposed will contribute to the creation of legal preconditions for public regulation, improvement of the financial and budgetary discipline of land authorities, rational use of budget funds, and elimination of departmental conflicts between regulatory authorities by the clear legislative delineation of their functions. It should be noted that for improving the legal mechanism for public regulation of land relations, experts in both the economic sphere and land management should actively cooperate. Joint actions will provide an opportunity to create conditions for the completion of land reform with the least damage to the agriculture of the country, which is the basis of food and economic security of the state.

Having identified the main areas for improving the legislative regulation of land relations, we consider it appropriate to implement these measures in the system of domestic regulations in order to achieve the above positive results.

The main requirements for the legal mechanism for public regulation of land relations are the following: mobility of legislation. Compliance with mobility is ensured by the presence of three components: legal sanctions for violations of budget legislation; economic regulators; measures for preventing violations of budgetary discipline. This will ensure the integral functioning of the control system and adaptation to the external environment; compliance with the Constitution of Ukraine, the Land Code, and other applicable regulations; strategic direction. 


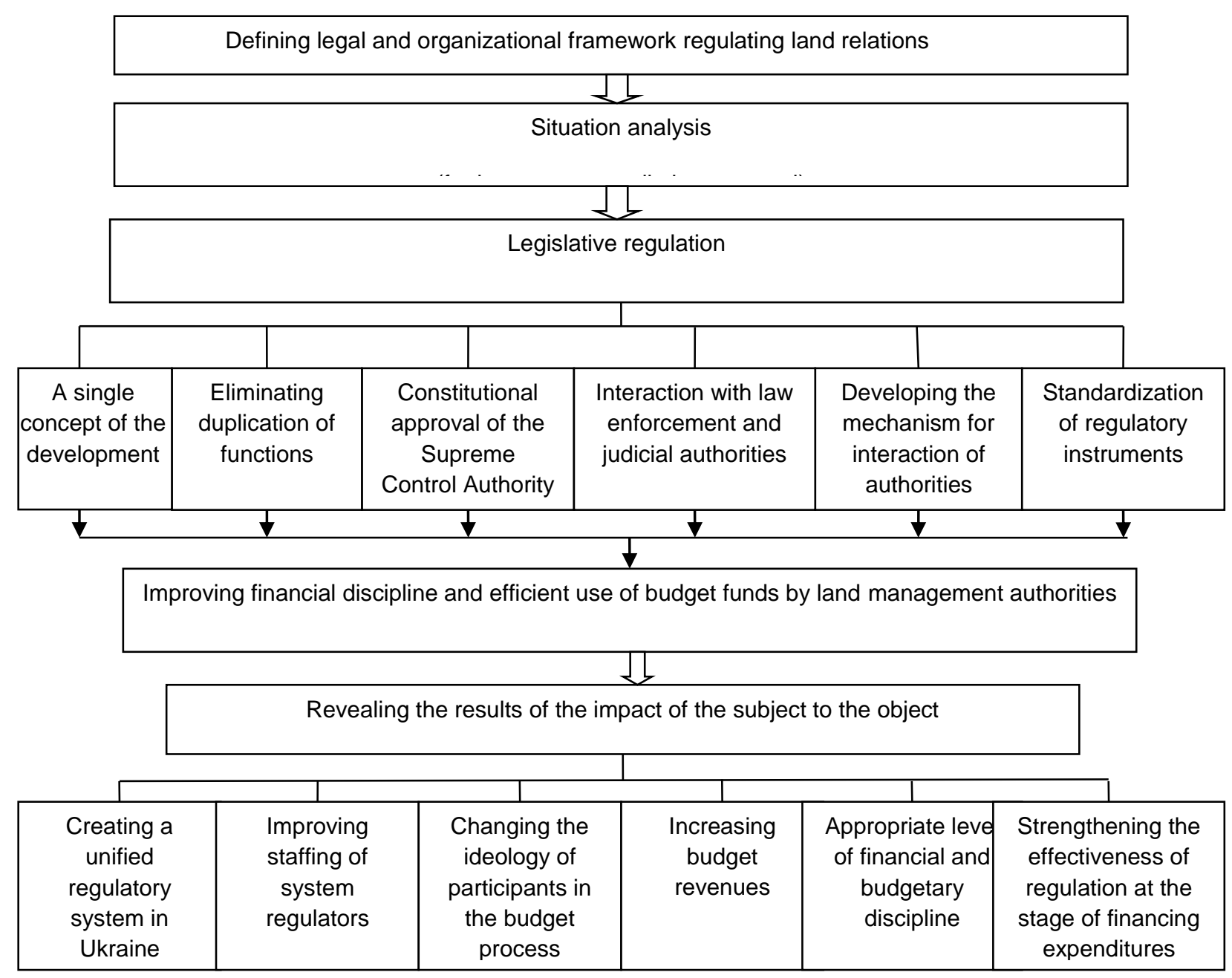

Figure 1. Measures for improving public regulation of land relations in Ukraine*

* Source: own development

The adapted structural model of the legal mechanism for public regulation of land relations is presented in figure 2.

We believe that the legally regulated process of public regulation will be a prerequisite for the completion of land reform, and solving the problem of introducing a full-fledged land market and its public regulation in Ukraine will allow forming a new strategy of public regulation aimed at developing land relations. The results of improving the legal mechanism for public regulation of land relations in Ukraine, in our opinion, are as follows: increasing the efficiency and investment attractiveness of the agricultural sector, land market formation, increasing transparency of land relations and protection of landowners, increasing legality in the budget sphere, creation of conditions for the prevention of illegal actions. 


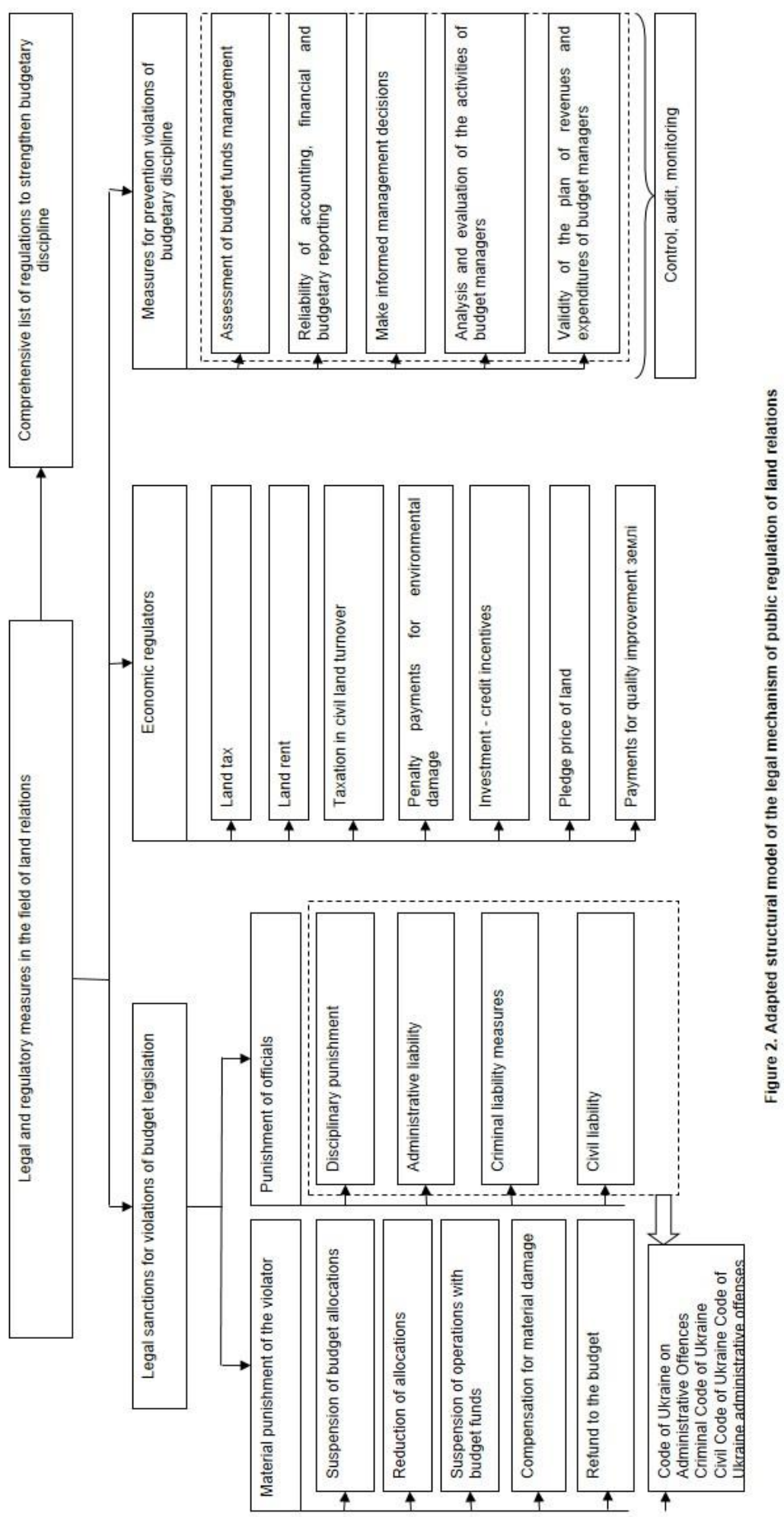




\section{CONCLUSIONS}

Thus, the lack of a comprehensive public policy in the sphere of land and a comprehensive program of action of land relations create a number of problems in the field of control. In order to eliminate them, we have improved the legal framework for public regulation of land relations by amending existing legislation (granting the right to control, eliminating duplication of functions in the system of state regulation, constitutional approval of the Supreme Control Authority, interaction with law enforcement and judicial authorities, developing the mechanism for interaction of authorities) and determination of authorities responsible for their implementation.

Requirements for legal maintenance of regulation of land relations in Ukraine have been defined. It has established that the most important step for Ukraine today is the step of forming the institution of a civilized land market. In this context, the formation of an appropriate developed legal framework, which would be aimed at addressing the issues of harmonization of public interests, the government, business, and community, remains a necessary task for the state. The above can be an essential prerequisite for sustainable development. The main ways for the development of public regulation of the agricultural land market have been determined. With such a solution to certain issues, it becomes possible to form an adequate mechanism for public regulation of the development of land relations and the rational use of land resources.

\section{REFERENCES}

1. Shestakovska, T.L. (2019), The current state and mechanism of implementation of state policy of land relations in Ukraine in terms of decentralization. Public administration and national security. № 4. URL: https://www.internauka.com/issues/administration2019/4/5223. [in Ukrainian]

2. Shchuryk, M.V. (2017), Preservation and protection of lands as key prerequisites for their improvement. Scientific Bulletin of Mukachevo State University. Ser. : Economics. Vip. 1. pp. 61-66. [in Ukrainian]

3. Borodina, O., Prokopa, I. (2015), Overcoming structural deformations in the agricultural sector of Ukraine: institutionalization and modernization of small-scale agricultural production. Ukraine economy. №4. Pp. 88-96. [in Ukrainian]

4. Kosovych, B. (2004), The structure of land relations in Ukraine: economic and legal aspect. Bulletin of Lviv State Agrarian University: Economics of AIC. №11 (2) 563 p. [in Ukrainian]

5. Miroshnichenko, A.M. (2009), Land law of Ukraine: textbook / A.M. Miroshnichenko. K .: Alert; CST; CUL, 712 p. [in Ukrainian]

6. Tretyak, A. (2008), Directions of formation of the state land policy, or change of priorities of land reform. Land Management Bulletin. № 1. pp. 21-33. [in Ukrainian]

7. Polishchuk, L. (2008), Land market: visible and hidden risks. Land Management Bulletin. № 1. pp. 9-21. [in Ukrainian]

8. Shestakovska T.L. (2016) Features of the formation of socially oriented clusters in Ukraine. Scientific Bulletin of Polissya. № 1. pp. 46-55. [in Ukrainian] 


\title{
EFFECTIVENESS OF THE PUBLIC ADMINISTRATION SYSTEM BASED ON THE IMPLEMENTATION OF THE EU EASTERN PARTNERSHIP PROGRAM IN UKRAINE
}

\author{
Yevheniy Kodis \\ Applicant of the National University "Chernihiv Polytechnic", Ukraine. http://orcid.org/0000-0002-2751-4963 \\ Email: kodisevgeniy@gmail.com
}

\begin{abstract}
The article systematizes the principles and results of the EU Eastern Partnership program in the field of public administration. The procedures of institution-building mechanisms and the model of functioning of the Twinning Program in the Southern and Eastern regions of the European Neighbourhood Policy are presented. It is established that the areas of implementation of the Eastern Partnership tasks are represented in three cross-cutting areas (civil society; gender equality; strategic communications) and seventeen grouped within four priorities (economic development and market opportunities; institution building and good governance; energy efficiency, interconnectedness, and climate change, people-to-people contacts and mobility. It is proved that the positive results of the public administration system based on the implementation of the EU Eastern Partnership Program in Ukraine are: security of the participating states, strengthening of political dialogue, implementation of economic and structural reforms and participation in a number of EU programs, etc.
\end{abstract}

Keywords: European Union, European integration, Eastern Partnership, public administration, association agreement.

\section{INTRODUCTION}

In recent years, international relations, integration processes and multi-vector cooperation have begun to develop rapidly. Usually, bilateral relations are formed within the framework of multi-vector interaction, and it is no longer appropriate to consider them separately because the principle of complexity and inclusivity is violated. On May 7, 2009, the European Union's Eastern Partnership Program was launched, with 6 countries participating: Ukraine, Armenia, Azerbaijan, Belarus, Georgia and Moldova. This cooperation is focused on the development of political, economic, energy spheres, as well as establishing contacts between people. In other words, the Eastern Partnership has defined promising relations between the European Union and Ukraine in the long term, which has led to the importance of considering them. The Eastern Partnership has not only theoretical but also practical significance for the countries involved in or adjacent to this Program.

Analysis of recent researches and published papers. The study of the Eastern Partnership as a system of establishing regional cooperation in Europe is devoted to a sufficient number of publications in the modern science of public administration. A significant number of materials are presented in the context of conceptualizing the content and nature of the Eastern Partnership, which is defined as one of the directions of the European Neighbourhood Policy. In the works of T. Sydoruk [1], the issue of 'Eastern Partnership' is presented as a model of gradual and partial integration with the EU. In the European Integration manual [2], scientists have identified promising areas for the development of the 'Eastern Partnership'. A. Honcharuk in his Ukraine Supports the Eastern Partnership as a Tool to Achieve EU Membership research raises the issue of prospects for cooperation between Ukraine and the EU in the framework of the Eastern Partnership Program to consider the prospects of its membership [3]. The list of instruments of the 'Eastern Partnership' and its EU funding is presented in the work of N. Hnydiuk [4]. However, despite the rather significant scientific contribution to the research area, more detailed research is needed on the results of the implementation of the EU's Eastern Partnership Program specifically for Ukraine.

Results of the research. The Eastern Partnership is one of the regional dimensions of the European Neighbourhood Policy (ENP), which was created after large-scale enlargement, i.e. when ten states joined the EU. In order not to create new territorial vectors in Europe, the European Union focused on the ENP, which is still in force today. The priorities are to bring Europe closer to its neighbours by promoting their socio-political and economic reforms, thus ensuring stability and strengthening peace.

A systematic analysis of domestic and European Studies shows the complexity of the nature of the ENP and the impossibility of identifying a single approach to its interpretation. It was found that the most objective is a comprehensive approach by which the European Neighbourhood Policy can be defined as a form of good neighbourly cooperation between the EU and third countries, aimed at streamlining the borders of EU neighbours using external management tools that regulate political, economic, cultural and other areas of cooperation.

The division of the ENP into the Eastern Partnership and the Union for the Mediterranean in 2008 led to additional mechanisms within the multilateral form of cooperation, namely: an institutional mechanism that uses a four-tier operational structure in the Eastern Partnership and a system of three common institutions in the Union for the 
Mediterranean. Within the framework of the bilateral form of cooperation for the Eastern Partnership countries, the Comprehensive Institution Building Program has been additionally introduced within the framework of the Institution Building Mechanism.

The EU's Eastern Partnership Program has found more concrete expression in the following flagship initiatives: integrated border management; promoting the development of small and medium-sized businesses; energy markets, energy efficiency and renewable energy sources; environmental management; the system of struggle against consequences of natural disasters and man-caused catastrophes.

For the effectiveness of the implementation of such reforms, trained institutions of public administration are needed. For this purpose, the Eastern Partnership developed a Comprehensive Institution Building Program, which, accordingly, was not included in the European Neighbourhood Policy. The EU's Eastern Partnership Program is often criticized, but there are certainly some positive results in its implementation. The author proposes to include the key positive points. Firstly, despite the crisis in the world economy, many participants in the Eastern Partnership (except Belarus) have carried out effective economic and structural reforms, which are primarily aimed at approximating economic legislation and technical standards of such countries with European ones.

Secondly, thanks to the creation of the Eastern Partnership, the absolute has happened reformatting of the post-Soviet space, as a result of which the Russian Federation has lost its monopoly on influence over post-Soviet countries, but still retains a dominant influence over some Eastern Partnership countries.

Thirdly, it is worth noting the key role of the Eastern Partnership in the security dimension, both for the entire EU and the Eastern Partnership countries.

Fourthly, political attention to Ukraine has significantly increased, and the Eastern Partnership countries have had the opportunity to significantly strengthen political dialogue, as well as participate in the formation of a common agenda (by participating in Eastern Partnership Summits, ministerial meetings and other formats of political involvement). Thus, there is another powerful platform for meetings with the leaders of EU member states at the highest level, in contrast to the bilateral summits, which are attended only by leading leaders of the EU institutions.

Fifthly, the Full and Comprehensive Free Trade Area between Ukraine and the EU has begun to operate, since 2016. In today's world, the European Union is a key trading partner, to which exports of goods from Ukraine are growing rapidly every year. Thus, according to the results of 2018, exports of goods from Ukraine to the EU significantly exceeded exports in 2013 by almost $\$ 3.4$ billion up to $\$ 20.16$ billion and amounted to $42.6 \%$ of total exports of Ukraine (Table \#1). In turn, the growth of exports occurs during the war (temporary occupation of the territories of the Autonomous Republic of Crimea and parts of the territories in Donetsk and Luhansk Oblasts.

\section{Table 1: Dynamics of Export-Import Transactions between Ukraine and the EU, billions of US dollars}

\begin{tabular}{|c|c|c|c|c|c|c|c|c|c|c|}
\hline Indicators & 2009 & 2010 & 2011 & 2012 & 2013 & 2014 & 2015 & 2016 & 2017 & 2018 \\
\hline $\begin{array}{l}\text { Dynamics of goods } \\
\text { expert from Ukraine } \\
\text { to the EU }\end{array}$ & 9.5 & 13.05 & 17.97 & 17.08 & 16.76 & 17 & 13.02 & 13.5 & 17.53 & 20.16 \\
\hline $\begin{array}{l}\text { Dynamics } \\
\text { imports of goods } \\
\text { from the EU to } \\
\text { Ukraine }\end{array}$ & 15.39 & 19.1 & 25.75 & 26.16 & 27.05 & 21.07 & 15.33 & 17.14 & 20.8 & 23.18 \\
\hline
\end{tabular}

\section{* Source: Official data of the State Statistics Service of Ukraine}

Trade with the Eastern Partnership countries has also increased significantly. Thus, in 2017, exports of goods to the five countries of the Eastern Partnership increased by as much as $29 \%$, respectively, imports by $30 \% 5$.

Sixthly, a positive result has been achieved in the context of the EU's dialogue with the Eastern Partnership countries on the conclusion of the Association Agreements and their parts. On June 27, 2014, Georgia, Moldova and Ukraine signed such documents, in turn, the first two countries were even ahead of schedule, which was caused by the significant impact of socio-political events in Ukraine. Those Eastern Partnership countries that have signed the Visa Facilitation Agreement have adopted special 'action plans' to prepare conditions for the further introduction of a visa-free regime with the EU. The first visa-free regime was granted to Moldova (April 2014), followed by Georgia (March 2017) and soon on June 12, 2017, Ukraine.

Seventhly, through participation in the Eastern Partnership, member countries have opportunity to directly participate in a number of programs, which operate based on the European Neighbourhood Policy or directly within the framework of the Eastern Partnership initiative. Such programs are focused on the development of specific areas (education, culture, science, small and medium business, innovation, academic mobility, urban infrastructure development and others). The list of such programs takes into account such initiatives as EU4Energy, EU4Business, EU4Youth, "Culture and Creativity", "Creative Europe", "Mayors for Economic Growth", "Erasmus+", "Horizon 2020", "Agreement of Mayors - Demonstration Projects", "Integrated Border Management" and others [5]. 
To strengthen the institutional capacity of the ENP member countries, the action plans provide for the introduction of an institutional development mechanism, which includes practical measures for the development of state bodies of Central and local authorities to implement the 'acquis communautaire' (EU legal system). They are aimed at the close cooperation between similar institutions of the neighbouring state and the EU member state and provide for consultations, training, study tours. This mechanism consists of Twinning projects, TAIEX activities and the SIGMA program.

Twinning and TAIEX institution-building mechanisms have become available to Ukraine through the ENP introduction. The Action Plan in the New Perspectives for Partnership, Economic Integration and Cooperation section states that to support the adaptation of legislation to EU norms and standards, the exchange of experience between civil servants and targeted consultations and support through the Technical Assistance Information Exchange Mechanism (TAIEX) will be used. [3]. The SIGMA program assists countries in modernizing their public administration systems. It became available to Ukraine in 2006. Its main purpose was to conduct an assessment of public administration in Ukraine based on SIGMA indicators to implement the Action Plan [4]. To date, the mechanisms of institutional development such as Twinning, TAIEX, SIGMA remain poorly studied in Ukraine.

Compared to other ENP Member States, Ukraine, apart from Azerbaijan and Armenia, is the only country that uses a fairly extensive legal and methodological framework. In Azerbaijan, recommendations for the implementation of Twinning projects and the completion of TAIEX applications [5] were adopted at the legislative level in 2009, which introduced a clear procedure for project preparation and implementation. In Armenia, Twinning procedures are governed by Government Decision No. 605 of May 29, 2009 and the guidelines for the use of the Twinning tool [1]. Mediterranean African countries do not develop special legislation for project implementation at all.

Ukraine has developed not only a legal framework but also a system for coordinating Twinning projects, which ensures the planning and registration of projects under Ukrainian legislation and tasks outlined in the Partnership and Cooperation Agreement; National Agency of Ukraine for Civil Service Affairs; EU Delegation to Ukraine; Twinning Administrative Office and Working Group on Issues coordination of the implementation of the Twinning instrument (Coordination group), which was created by a joint order of the Ministry of Economy of Ukraine and the Main Directorate of Civil Service of Ukraine [6]. The EU aid resources management system is also important in the implementation of Twinning projects. For the ENP Member States, the EU has developed two systems: decentralized, which is used in the Southern region, and centralized, which is used in the Eastern region. Accordingly, Ukraine uses a centralized system. The prevailing management system determines the institution that will have the appropriate authority and will act exclusively as the contracting authority. In a decentralized system, the institution authorized to enter into contracts is the Administrative Office. In a centralized system, such an institution is the European Commission [7]. She plays an important role in the preparation and implementation of Twinning projects. This project management system excludes any interference in project financial management and selection of partners from the EU Member States. The Administrative Office serves as the Secretariat, which advises the beneficiary bodies involved in the preparation and implementation of Twinning projects and implements the tasks set by the Coordination Group. This system is inflexible and can negatively affect the project implementation process in Ukraine, as it excludes any initiative on the part of central executive bodies.

Analysing the regulatory and methodological framework, the system of coordination of Twinning projects in Ukraine, we conclude that they are ineffective. In our opinion, the strategic problem is that there is no single coordination centre in Ukraine that will implement the policy of European integration in the country. Issues of European integration are scattered between the Ministry of Economic Development, Trade and Agriculture, the Ministry of Justice of Ukraine, the Ministry of Foreign Affairs of Ukraine, the National Agency of Ukraine for Civil Service Affairs and numerous state committees. Their powers are not coordinated with a single centre. The only coordination mechanism is a meeting of the Ukrainian part of the EU-Ukraine Cooperation Committee (a bilateral cooperation body following the Administrative Office). However, depending on the change of government, the regularity of their meetings changes from once a month to once a quarter. In turn, issues of European integration require daily coordination.

In addition to Twinning projects, Ukraine also uses TAIEX as part of its institutional building mechanism. Note that in the Ukrainian language this abbreviation does not have an adequate translation, so in regulations and other documents the English version of the name is used.

This mechanism has been available to Ukraine, since 2006 under the Decision of the European Council 206/62/EC, according to which TAIEX became available to the countries participating in the European Neighbourhood Policy and Russia [2].

Among the countries implementing TACIS measures and members of the ENP, Ukraine was the first to implement Technical Assistance in the Field of Information Exchange (TAIEX). The TAIEX official introduction took place on November 22, 2006 during a training seminar for government officials of Ukraine, organized by the Twinning Administrative Office in cooperation with the European Commission's Directorate-General for Enlargement and the EU Delegation to Ukraine.

By participating in the TAIEX events, Ukraine solves the following tasks:

- Implementation of national priorities;

- Solving practical problems of Ukraine's development and integration into the EU;

- Increasing the administrative and institutional capacity of public authorities;

- Establishing 'network' relations with European partners [4]. 
Within the TAIEX framework, Ukraine can receive three types of services related to the organization:

- Sending experts from the EU Member States to the beneficiary country to advise on legislation and the interpretation of the acquis communautaire, as well as to support administrative harmonization actions to implement and enforce the acquis communautaire;

- Seminars and workshops to address issues related to the EU policies, legislation and functioning. Such assistance may focus on the needs of an individual country or group of countries facing the same difficulties, i.e. it may be provided on an individual or multilateral basis with the participation of more than one institution. The format of the event for several countries simultaneously makes it possible to create a network for the exchange of experience between beneficiary countries;

- Study visits to the EU countries, enabling the beneficiary countries to understand how the EU Member States address practical issues related to the implementation and enforcement of the acquis communautaire and aspects of interaction with stakeholders [2].

TAIEX measures provide for three forms of assistance through secondment of one to two experts from the EU Member States to Ukraine for a short period of up to one week; study visits to the EU Member States, where a maximum of three representatives from Ukraine can take part; conducting seminars and working meetings in Ukraine.

Under the TAIEX mechanism, Ukraine can receive assistance in two ways. The first is that at the initiative of the Ukrainian side the public authority of Ukraine submits to the National Agency of Ukraine for Civil Service an application for technical assistance, the second that at the initiative of the European side the European Commission announces the possibility for the Ukrainian side to participate in TAIEX events abroad.

Consequently, Ukraine's use of the TAIEX institutional development tool is characterized by almost the same problems as the process of implementing Twinning projects.

The lack of qualitative indicators in the implementation of TAIEX measures shows that the Twinning and TAIEX mechanisms are not used as mechanisms for reforms in the country, as a single-centre for coordination of European Integration Policy and the necessary reforms has not been established. TAIEX is used in parallel with the reforms implemented by the President. In such a situation, as in the case of Twinning projects, it is necessary to subordinate the Administrative Office of the Twinning Program to the President of Ukraine and include quality indicators in the reports on the results of TAIEX activities.

In addition to the listed mechanisms of institution building, Support for Improvement in Governance and Management (SIGMA) is also available for Ukraine. The main task of the Program is to assess the system of public administration in transition countries [5].

A special feature of the SIGMA program is that its evaluation does not cover the entire operation of the management system. It is limited to general government systems of administrative management and broader institutional schemes that determine the functioning of institutions, namely:

- System of policy formation;

- The legal basis of public administration (including the Constitution);

- Human Resources Management (Public Service);

- Public expenditure management system;

- State internal financial control;

- Public procurement system; and

- External audit.

In 2005, Ukraine formally requested the management of the SIGMA program to evaluate the public administration system in Ukraine. Based on the results of the assessment, a proposal was formulated, which noted that Ukraine needs to implement a systemic reform that will define constitutional responsibilities and strengthen the rule of law. However, at the present stage, Ukraine is not yet ready for reforms of this magnitude. Within the framework of SIGMA recommendations, the Code of Administrative Services was developed and recommendations on the Law of Ukraine on Public Service were developed.

According to SIGMA's assessment, the biggest problem in the public administration system of Ukraine is the lack of independent state control over the activities of public authorities. Until now, state institutions do not function using democratic procedures and mechanisms. Procedures for public discussions, consultations with stakeholders take place formally only [8].

All the presented mechanisms of institutional development became available to Ukraine thanks to the development of the ENP, the main task of which was to avoid the appearance of new dividing lines. The implementation of such a common approach has brought together a large number of heterogeneous countries in terms of geographical, economic, political and other indicators within the framework of the neighbourhood policy. As a result, in 2008 the European Neighbourhood Policy was divided into two areas: Eastern as Eastern Partnership and Southern as Union for the Mediterranean.

Ukraine is covered by the Eastern Partnership, which provides for the introduction of an additional mechanism of cooperation within the framework of institutional development, namely the Comprehensive Institutional Development Program. Accordingly, the next section will analyse the possibilities of this Program and the possible risks associated with its implementation. 


\section{CONCLUSIONS}

Thanks to the development of cooperation between the European Union and the six Eastern Partnership Member Countries, their involvement in multi-vector programs of the EU and the Eastern Partnership, as well as based on participation in various effective institutional platforms, the awareness of citizens of such countries about the European Union and positive opportunities within the Eastern Partnership has significantly increased. Promoting cooperation and integration with the European Union allows to adopt European values, raise awareness of the citizens of the respective partner countries about the experience and prospects of the EU countries, significantly strengthens their perception of themselves as Europeans. In the course of the study, it was found that the institutional development mechanism is being implemented in Ukraine, namely Twinning projects, TAIEX events and the SIGMA program. It is shown that in Ukraine these mechanisms are implemented within the centralized system of management of EU aid resources, which limits interference in project financial management and selection of partners from the EU Member States.

It was found that today Ukraine is not ready to introduce a decentralized system due to shortcomings in budget planning and non-transparency of public financial management. If it is implemented in the EU funds management system of Ukraine, it is advisable to develop a preparatory stage for the decentralized system for managing EU aid resources, which will ensure an independent audit of the external aid management system of Ukraine and, according to its results, determine the responsible state institution that will carry out the overall coordination of the decentralized system at further stages of its implementation.

\section{REFERENCES}

1. Sydoruk, T.V. (2012), Politics of the European Union's Neighbourhood in Eastern Europe: Model of Integration without Membership: Monograph/Sydoruk, T.V. - Lviv: PAIS, 444 p. [in Ukrainian]

2. European Integration: Tutorial/Generally edited by Prof. I.A. Hrytsiak and D.I. Dzvinchuk. Ivano-Frankivsk: City of NV, 2013. 464 p. [in Ukrainian]

3. Honcharuk, A. Ukraine Supports the Eastern Partnership as a Tool to Achieve the EU Membership. URL: http://www.president. gov.ua/news/13265.html [in Ukrainian]

4. Hnydiuk, N.A. (2010), The Instrument of the European Neighbourhood and Partnership and Financial Assistance of the European Union/N.A. Hnydiuk; Generally edited by V. Yu. Streltsov. K.: Knyha Plus, 2010. 192 p. [in Ukrainian]

5. Joint Staff Working Document 'Eastern Partnership - 20 Deliverables for 2020. Focusing on Key Priorities and Tangible Results', URL: http://eap-csf.org.ua/onovleno-dokument-shhodo-klyuchovih-prioritetiv-ta-ochikuvanihdosyagnenshidnogo-partnerstva-do-2020-r/[in Ukrainian]

6. Onyshchuk I., Onyshchuk S., Rudenko O. (2020) Conceptual Basis of Legal Monitoring Implementation in The System of Public Administration. Journal of History Culture and Art Research. 9 (1), pp.345-353. [in Turkey]

7. Neighbourhood at the Crossroads: Implementation of the European Neighbourhood Policy in 2013. Joint Communication to the European Parliament, the Council. The European Economic and Social Committee and the Committee of the Regions. Brussels, 27/03/2014 JOIN (2014) 12 final. URL: http://www. eeas.europa.eu/enp/pdf/2014/joint_communication_en.pdf[in Ukrainian]

8. Rudenko O., Dyvnych H. (2019) Conceptual comprehension of strategies for ensuring social stability in the interests of the citizens and the safety of the state. Fundamental and Applied Researches in Practice of Leading Scientific Schools, 31(1), pp.173-177. [in Canada] 


\title{
INTERACTION OF STATE AUTHORITIES OF UKRAINE WITH EUROPEAN DEVELOPMENT PARTNERS: PROBLEMS AND DIRECTIONS OF THEIR SETTLEMENT
}

\author{
Anatoliy Kutsevol \\ Applicant of the National University "Chernihiv Polytechnic", Ukraine. http://orcid.org/0000-0003-3704-8908 \\ Email: anatolii.kutsevol@gmail.com
}

\begin{abstract}
The article evaluates the specifics of interaction between state authorities of Ukraine and European development partners. The influence of international technical assistance and foreign direct investment on the dynamics of the country's risk indicator as one of the general indicators of development is presented. The problems of interaction of state authorities of Ukraine with European development partners (lack of modern skills for managing projects and processes, use of paper document management, lack of clarity of the institutional structure, etc.) are identified. The directions of the settlement of problems of interaction of public authorities of Ukraine with the European partners on development are defined: to revise and enter necessary changes to the operating regulations of Ukraine in the direction of their coordination; to provide effective information and communication support of the current processes of cooperation at the level of the regions of Ukraine and international financial organizations; to improve organizational and institutional support; and improve the national system for monitoring and evaluation of international projects, etc.
\end{abstract}

Keywords: public administration, interaction, public authorities, international technical assistance, European integration, foreign direct investment.

\section{INTRODUCTION}

The dynamic process of deepening the internationalization of socio-economic life, which generates increasing interaction and coordination of different levels of development of states in the formation and implementation of an international development strategy, significantly increases the priority of external financial resources for the country's economy. International technical assistance is a key component for external financing of countries with economies in transition, to a certain extent of which Ukraine also belongs. One of the possible approaches to measuring the effectiveness of international technical assistance is parametric evaluation, which can be presented as an assessment of the impact of international technical assistance and foreign direct investment on a generalized indicator of the country's development. To identify the degree of impact of selected elements of external financing on the overall level of sustainable development of the country, it is proposed to use a panel formed from individual data of 15 post-Soviet countries (including the Baltic countries Estonia, Latvia and Lithuania) over a relatively long (ten years) period. Although these countries vary in scale, they have much in common in terms of the recent historical past, the peculiarities of the transitional state of economic, political and social life, and the nature and trends of international technical assistance.

Analysis of recent researches and publications. The studied problems are presented in the scientific developments of domestic specialists in the field of public administration, namely: V. Averianov, Ye. Afonin, M. Baimuratov, V. Vasylenko, M. Vasylieva, A. Dehtiar, V. Muraviov, N. Nyzhnyk and V. Rebkalo, etc. The article is designed to identify current problems of interaction of public authorities of Ukraine with development partners in the context of European integration and promising areas for their settlement.

Results of the research. In Ukraine, institutions of international importance are financing a set of programs in various areas of activity, and their size and diversity are steadily increasing. However, we note that the methods, tools and principles of Public Administration in the field of international financing remain unchanged. Therefore, there are a number of problems at different stages of public administration in the field of international technical assistance.

Emerging conflicts are usually associated with the emergence of specific risks, which need to be constantly monitored, which necessitates the development of effective mechanisms to assess the level of risks and mechanisms to prevent, neutralize or avoid them. The lack of such mechanisms leads primarily to various crises and social conflicts, which are also an incentive to expand the negative impact of contradictions and possible risks. When considering the possible causes of public administration problems in the field of international technical assistance, it should be noted that the source of their occurrence is exogenous and endogenous factors. An important factor in the imperfection of the public administration system is the long-term political crisis in Ukraine, first of all, existing contradictions arise in the absence of a balanced system of state power and the level of development of the country's political system [1].

We note that the manifestation of such negative moments has a detrimental effect on the economy. Obtaining loans from the International Monetary Fund, which are not used for their intended purpose, hinder the implementation of major reforms for Ukraine, focusing only on eliminating the corruption component does not contribute to resolving crisis issues at the state and local budgets. An innovative view of the situation that has developed in recent decades needs to be considered, first of all, this direction is the decentralization of the public administration system. 
The next, no less important factor in the effectiveness of systemic reforms in various spheres of public activity is the identified requirements for the use of possible competencies of public administration employees. Also, the system of public administration in general, considering structural and organizational gaps, has a personal and functional imbalance, namely, inconsistency or partial compliance of the employee with his established professional, cultural and moral and other qualities.

The choice of a summary indicator as an endogenous variable is a fundamentally important issue given the need to comprehensively cover the impact of international technical assistance and foreign direct investment on the political, economic and social development of the country. For such a summary indicator, a country risk assessment is offered by numerous international and private agencies.

Country risk as a generalizing indicator was chosen precisely because the author wanted to assess the parallel impact of international technical assistance and foreign investment on a certain generalizing indicator that reflects the level of sustainability of the country over ten years. And one of such indicators, according to the author, is the country's risk indicator.

That is, as an effective indicator in the study, the indicator 'country risk' is used, which reflects the evolution of the general situation in the country (as opposed to, for example, purely economic indicators as a gross domestic product) and can serve as a barometer in the context of European integration.

The concept of risk is all-encompassing, it exists in any sphere of human life. Country risk begins with the risk of foreign direct investment since all business operations at the international level are associated with an increased degree of risk. Business transactions carried out across international borders carry additional risks other than those that take place within the country [1].

There are different classifications of country risk components: detailed and less detailed. The most concise covers political, economic and financial risks. Among the detailed ones, we note one that covers six categories of risks, namely: economic risk, displacement risk, currency risk, location risk or neighbourhood risk, sovereignty risk, and political risk (Fig. 1).

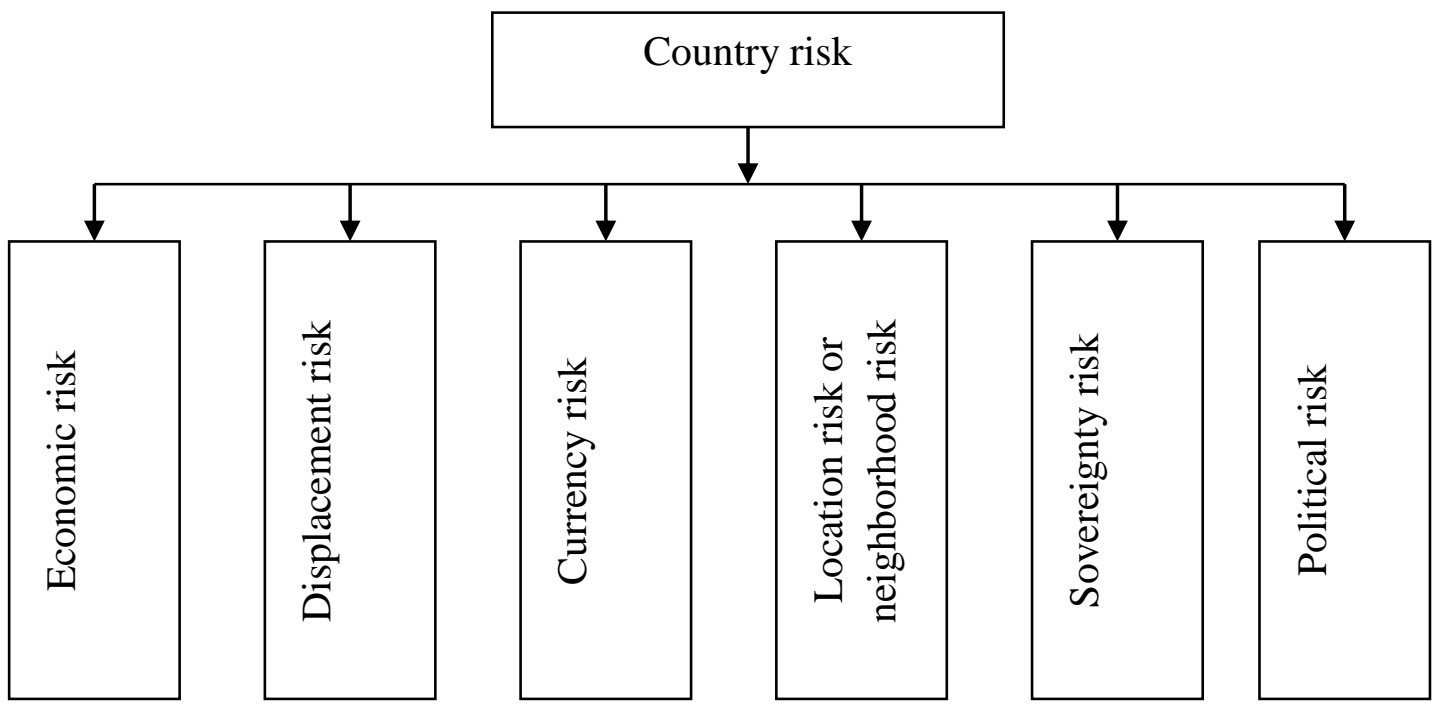

Figure 1 Types of risks in the mechanism of interaction of state authorities of Ukraine with development partners in the conditions of the European integration

In any case, it is very difficult to draw a clear line between the various risk components of a country, which, given the relationship of the domestic economy with the political system and the influence of the international community, often overlap [2].

Economic risk arises due to possible negative changes in the fundamental economic goals of the state (in tax, monetary, international policy, due to interference in the process of creation and distribution of wealth) or due to significant changes in the country's comparative advantages (e.g. lack (or depletion) of resources) industrial decline, poverty and demographic change, etc.) [2].

Economic risk is often intertwined with political risk. In statistical terms, this type of risk can be statistically estimated by such macroeconomic indicators as, for example, GDP and GNP, as well as GDP per capita [3].

The displacement risk is associated with the decision of public authorities of a country in which a foreign company operates, to limit the movement of capital. Such restrictions may make it difficult to return the profits, dividends, or overall capital of the company to its country of origin. 
Currency risk is an unexpected adverse change in exchange rates and covers unexpected changes in the exchange rate regime, such as the transition from a fixed to a floating exchange rate. Location or neighbourhood risk means side effects caused by problems in the region, in the country's trading partners, or countries with similar characteristics.

Sovereign risk is an indicator of a government's ability and goodwill to meet its credit obligations. The history of the concept actually began with this indicator 'country risk' (sovereignty risk).

Political risk refers to the risk of change in political institutions, especially in the legal system, arising from changes in government, social structure or other non-economic factors. It should be noted that political risk assessment requires an analysis of many factors, including the relationships of various social groups in the country, the decision-making process in the government, and the country's history.

Each of the country's risk types covers a set of quantitative and qualitative indicators that are summarized through an appropriate weighing system. Weights depend on the importance of each of the indicators and the type of risk. The generalized 'country risk' (sovereignty risk) indicator is assessed by various international organizations and agencies. Their methodology varies and is not always transparent, since the fate of countries literally depends on the conclusions of such well-known agencies as, for example, Moody's and Standard \& Poor's.

Thus, the initial hypothesis of the study is that the level of risk of the country as an endogenous variable reacted differently to two main types of external financial inflows: international technical assistance and foreign direct investment. The choice of foreign investment and international technical assistance as explanatory variables is due to the following.

The conditions for the provision of international technical assistance and the inflow of foreign direct investment are fundamentally different, which may cause ambiguity in the attitude of the recipient. Besides, for an international donor organization, the risk is an essential component of investment, as opposed to technical assistance, whereas international technical assistance is essentially risk-free.

For the recipient country of foreign direct investment is an important factor in the development and active and full entry into the international business environment [4-5]. And international technical assistance, in turn, can be both paid and free for the recipient country, as well as provided under certain conditions, such as subject to certain structural changes [6].

There are also different channels for international technical assistance and foreign direct investment. While international technical assistance comes through government agencies, foreign direct investment is mostly through private businesses. This creates different levels of responsibility and control over their direction and use. It is obvious that in the private sector, such control is more motivated and easier from an organizational point of view [2-8].

All this, in our opinion, can lead to different levels of intensity and return on investment and international technical assistance. Thus, the foreign direct investment can be a more important factor in sustainable development than international technical assistance.

Contradictions in the organization of interaction between public authorities and the EU development partners on the amount of financial resources and implementation of international technical assistance programs in Ukraine, provoking problems that are currently manifested in the study area (Table1).

Table 1: The main problems in organizing the interaction of public authorities of Ukraine and the EU development partners

\begin{tabular}{|c|c|c|}
\hline $\begin{array}{l}\text { Item } \\
\text { No. }\end{array}$ & $\begin{array}{c}\text { Stages of International Technical } \\
\text { Assistance Management }\end{array}$ & Problems that Arise at a Certain Stage of Management \\
\hline 1 & $\begin{array}{l}\text { Stage of planning projects and } \\
\text { assistance programs }\end{array}$ & $\begin{array}{l}\text { Problems in the direction of coordination of development } \\
\text { strategies and involvement programs. Contradictions in the field } \\
\text { of final beneficiaries of international technical assistance projects. }\end{array}$ \\
\hline 2 & $\begin{array}{l}\text { Stage of implementation of } \\
\text { international technical assistance } \\
\text { projects }\end{array}$ & $\begin{array}{l}\text { Insufficient institutional capacity to develop programs, } \\
\text { qualification of specialists, slow registration of projects, poor } \\
\text { coordination of donors, lack of transparency and accountability of } \\
\text { the implementation process. }\end{array}$ \\
\hline 3 & $\begin{array}{l}\text { Stage of monitoring and evaluation } \\
\text { of projects and programs of } \\
\text { international technical assistance }\end{array}$ & $\begin{array}{l}\text { There are practically no processes of monitoring and evaluation, } \\
\text { first of all, preliminary evaluation of projects, there are no } \\
\text { mechanisms for evaluation of projects and their effectiveness, } \\
\text { there is no free public access to information about projects and } \\
\text { their implementation. There is no system for monitoring donor } \\
\text { activities. }\end{array}$ \\
\hline
\end{tabular}


Source: Compiled based on [2-4]

Studies also show that an important factor in the effectiveness of international technical assistance is its form associated with the targeted use of assistance. Thus, international technical assistance, which takes the form of physical capital and is directed, for example, to road construction, improves the country's infrastructure and can contribute to investment to a certain extent, since it facilitates communication and transportation of goods. Assistance in the form of net financial income, as practice shows, does not contribute to the inflow of investment, as it is poorly controlled [6].

We note that international technical assistance and foreign direct investment can take the form of either stock or inwards. Because it is very difficult to identify flows, and a discrete amount of foreign investment can have a negative value for certain periods, which is especially evident in countries with unstable economies, the model used cumulative foreign direct investment. To ensure methodological unity, the indicator of international technical assistance is also formed as a cumulative.

The reason, obviously, lies in the fact that, unlike international technical assistance, foreign direct investment has the following obvious advantages. Firstly, they shift a significant share of risk from the domestic investor to the external investor. Secondly, it is the only external financial resource that directly affects the formation of fixed capital as an important factor in economic growth. In turn, foreign direct investment, generating profits in the private sector, potentially helps to repay the country's external debt, which undoubtedly reduces the country's risk.

However, international technical assistance and foreign direct investment are not mutually exclusive. Figuratively speaking, they are intended to 'treat' a particular country, act, as noted above, differently. In general, if investment affects the cause of the 'disease', i.e. 'cures' from within, then technical assistance affects only its symptoms.

To this should be added such an important factor as the conditions for providing certain types of assistance. For example, the policy of states on the terms of international technical assistance is like shock therapy, which is often perceived very negatively by the population and with unknown long-term results can obviously worsen the social, economic and sometimes political situation in the short term. Added to this (as evidenced, for example, the experience of many developing countries and countries with economies in transition as regular recipients of international technical assistance, the problem of corruption of certain government agencies and their poor control in terms of targeted use of international technical assistance, which also nullifies programs and projects.

The solution to this problem may be to opt for a policy of synergistic use of international technical assistance and foreign direct investment. Managers responsible for decision-making in both donor and recipient countries for international technical assistance and foreign direct investment should assess how international technical assistance can best be used to stimulate foreign direct investment.

One possible approach is to direct international technical assistance not only to the public but also to the private sector, for example, to improve infrastructure, to the development of supply and transport systems for potential investors. While international technical assistance to the private sector may lead to a reduction in social assistance, the potential synergistic effect between international technical assistance and foreign direct investment cannot be ignored, as in world practice it has a long-term positive impact on the economic development of the recipient country.

In such circumstances, international technical assistance also loses some of its weaknesses, which usually worsen its effectiveness, since, by analogy with foreign investment coming through private channels, its intended use can be better controlled.

In this context, the choice of strategy by the government is very important: to respond to risks or eliminate the causes of their occurrence. And in the case of the latter, it is important to ensure a mechanism for implementing and monitoring the intended use of assistance.

Thus, at the stage of planning projects and assistance programs, the key point is to ensure consistency of priorities of Ukraine's development strategies and international technical assistance programs and to involve future beneficiaries in the planning process. At the implementation stage, it is necessary to increase the institutional capacity of public authorities to develop strategic programs, coordinate donors, quickly register international technical assistance projects and programs, and ensure transparency and accountability of the entire process of implementing international technical assistance programs and projects. The monitoring and evaluation phase, which is currently virtually absent, should be strengthened by clear mechanisms for joint evaluation (current and final), provide free public access to information on the state of cooperation with individual donor countries, the EU, the UN, etc. [5].

To improve the management system of international technical assistance in Ukraine, it is necessary to strengthen the system of monitoring the status of project implementation, the use of financial resources. To this end, it would be advisable in the public administration system of international technical assistance to carry out in the short and mediumterm [4] the following actions: to develop a single system of reporting, the responsibility borne by one institution, which will provide for the ability to compare and understand what changes have occurred after the completion of the project; to introduce amendments to the law on state secrets to increase the transparency of management; strengthen transparency in the activities of Public Administration bodies by implementing a web-based reporting system, creating and ensuring transparency in the activities of the Working Group on the implementation of a specific International Technical Assistance Project. If the working group really plans to improve the effectiveness of the use of external assistance, its leader should provide for the involvement of other stakeholders who have significant expertise and are willing to help [7]; develop an 
action plan for capacity building at all levels of the institutional structure; strengthen the role of parliament in the governance structure of the public sector of the economy.

\section{CONCLUSIONS}

Given the imperfection of the national system of coordination of external assistance, it is necessary to understand the real consequences of attracting and using this assistance. Borrowing and irrational use of resources of international financial organizations make the country's economy increasingly vulnerable and dependent on donor support. The control by the authorities will allow identifying the weak cities of the state's development, to direct aid to those who really need it, and not to the corrupt goals of politicians and foreign development agencies. The nature of any assistance is such that it necessarily causes dependence, and in the case of recipient countries, it is better known as 'political dependence', encouraging donor intervention in political processes, in particular, making decisions that are significant for the state. It should be borne in mind that donors, above all, guard their interests, aim to satisfy the interests, values and incentives of their country, as well as provide their citizens with the expected results to support cash flow. A critical approach to public administration, in particular, the analysis of shortcomings and an effective mechanism of accountability for the implementation of assistance in Ukraine will help reduce the risk of political and economic pressure in favour of the donor country, will avoid its misuse.

Unlike foreign investment, international technical assistance does not encourage reform to the same extent as it is officially declared by international organizations. In this context, it is very important to choose a strategy on the part of the government of the country: to improve the business environment, making it more attractive to investors, or to look for assistance that, despite all the benefits, obviously does not guarantee development. It is also important when choosing policies in favour of receiving assistance to ensure a transparent mechanism for implementing relevant programs and projects and monitoring the targeted use of international technical assistance.

\section{REFERENCES}

1. Makota, H.Z. (2015), Directions for Improving Public Administration of Ukraine's International Technical Cooperation with the EU. Mechanisms of Public Management. No. 7-8 (21-22). P. 38-46. [in Ukrainian]

2. Kaur, N., Sithou, L. Governance of Development Assistance: Issues and Challenges. URL: http://ic-sd.org/wpcontent/uploads/sites/4/2016/06/Development_Assistance_-_Full_Paper.pdf. [in Ukrainian]

3. Kulinich, O.V. Grant writing: Recommended Method for Public Authorities to Write Project Applications/Writing staff: O.S. Zinchenko, O.V. Kulinich, P.Yu. Kulish; 2nd ed., Ext. and processed. Kharkiv: Zoloti Storinky, 2015.80 p. [in Ukrainian]

4. Humeniuk, V. International Technical Assistance: Effective Management or Control? URL: https://eu.prostir.ua/files/1327073026877/TA_edited_final_19.01.pdf. [in Ukrainian]

5. Lypova, T.V., Kolosova, V.P. (2013), Public Management of External (Pre-accession) Resources: The Experience of Poland. Finance of Ukraine. No. 2. P. 83-92. [in Ukrainian]

6. Shestakovska, T., Radchenko, O., Streltsov, V., Radchenko, O., Chernov, S. (2020). Ensuring environmental safety of the food industry: Influence on leadership positions in the economy. Ukrainian Journal of Ecology, 10(3), 19-23. [in Ukrainian]

7. On the Creation of a Unified System of Attraction, Use and Monitoring of International Technical Assistance: Resolution of the Cabinet of Ministers of Ukraine No. 153 of 15/02/2002. URL: http://zakon2.rada.gov.ua/laws/show/153-2002-\%D0\%BF. [in Ukrainian]

8. Durglishvili N., Shestakovska T., Kushnir S. (2018) Competitiveness of the agrarian business in the context of maintenance of leadership positions on the market. In: Strielkowski, W. (ed.). Proceedings of the 2nd International Conference on Social, Economic and Academic Leadership (ICSEAL 2018), Advances in Social Science, Education and Humanities Research, Vol. 217, P. 177-184. [in India] 


\title{
CUSTOMS VALUE CALCULATION PROBLEMS AMID FOREIGN TRADE ACCOUNTING, TAXATION HARMONIZATION AND USING INNOVATIVE TECHNOLOGIES
}

\author{
Mykhailo Vasyliev \\ Post-graduate student, Department of Audit, Accounting and Taxation, Central Ukrainian National Technical University, \\ Kropyvnytskyi, Ukraine. https://orcid.org/0000-0002-0164-6538 \\ Email: m.vasyliev2020@gmail.com
}

\section{ABSTRACT}

The article is dedicated to the research of customs value calculation problems amid foreign trade accounting and taxation harmonization current state. Comparative analysis of customs value and historical costs was made. Main differences, characterizing each of the categories for its characteristics, were revealed. Measures to help improve the process of customs value calculation were offered. Ways to improve current legislation to further foreign trade accounting and taxation harmonization were defined. We suggested to use innovative technologies for solving problem.

Keywords: foreign trade, customs value, customs control, customs duties, historical costs, value added tax

\section{INTRODUCTION}

The category of customs value has signs of legal and regulatory character and is used in accordance with the purposes, determined in the Customs Code of Ukraine [10]. Based on its economical and accounting components, it is always in the practical workers' area of interests, and it became lately a material for the scientific researches.

The law defines the customs value of goods transferring across the customs border as the value for customs purposes, that is based on the price, that was paid or will be paid in the future for the goods.

Customs value structure has the following list of costs, which were paid by the importer or will be paid in the future:

- The value of goods according to the list, mentioned in the invoice;

- $\quad$ Commission or agent's reward except for reward for sales promotion abroad;

- The cost of packing materials and packing services;

- The cost of goods and services in case they are delivered on free of charges basis in a direct or indirect manner, or the cost of goods was discounted and that value was not indicated in the invoice as the cost of goods (or their spare parts);

- $\quad$ Royalty or any other license payments, which should be paid by the importer as the express condition for further goods sales;

- A certain part of earnings of any further sales or use of goods;

- Costs of transportation and insurance of goods till the point of entry to Ukraine.

The customs value is connected to the historical cost - the cost of recognizing goods as the assets of the company if it will gain economic benefits in the future. The definition and the elements of historical cost are defined in the Regulations (standards) of accounting No 9 "Inventory".

Historical cost includes the following components:

- Costs, paid according to the contract to the seller minus indirect taxes;

- Amount of import duties;

- Amount of indirect taxes in the case when they are not reimbursing to the company;

- Transportation costs, including transportation risks insurance costs, costs of loading operations;

- Other expenses connected to goods purchase and making goods suitable for further use (direct material costs, other costs to adapt and improve quality characteristics of goods).

To my opinion, it makes sense to compare characteristics of customs value and historical value of goods (table 1).

Table 1 Comparative analysis of customs value and historical costs of goods characteristics

\begin{tabular}{|l|l|l|l|}
\hline No & Characteristics & Customs value & Historical costs \\
\hline 1 & Source & Customs code of Ukraine & $\begin{array}{l}\text { Regulations (standards) of } \\
\text { accounting No 9 "Inventory" }\end{array}$ \\
\hline 2 & Main purpose & $\begin{array}{l}\text { Customs duties calculation and } \\
\text { other foreign trade government } \\
\text { regulation measures }\end{array}$ & $\begin{array}{l}\text { Implementation of the common } \\
\text { methodological basis of current } \\
\text { assets balance cost }\end{array}$ \\
\hline 3 & $\begin{array}{l}\text { Types of business activities, } \\
\text { which defines the elements }\end{array}$ & $\begin{array}{l}\text { import customs regime; } \\
\text { export customs regime; }\end{array}$ & $\begin{array}{l}\text { goods purchase for cash; } \\
\text { goods production; }\end{array}$ \\
\hline
\end{tabular}




\begin{tabular}{|l|l|l|l|}
\hline No & Characteristics & Customs value & Historical costs \\
\hline 4 & of costs & $\begin{array}{l}\text { Exporary import customs regime; } \\
\text { other customs regime }\end{array}$ & $\begin{array}{l}\text { share capital payment; } \\
\text { other }\end{array}$ \\
\hline 5 & $\begin{array}{l}\text { Value calculation methods } \\
\text { existence }\end{array}$ & $\begin{array}{l}\text { Customs authorities perform } \\
\text { customs value control during } \\
\text { customs procedures }\end{array}$ & $\begin{array}{l}\text { Internal (audit division) and } \\
\text { external control (tax authorities or } \\
\text { other state control authorities) }\end{array}$ \\
\hline 6 & Types of values existence & None & A simple method (arithmetical) \\
\hline
\end{tabular}

Information from table 1 characterizes both categories with their main signs and gives a certain economic idea, first of all, on their place in the business activity of the company. In common with the Tax Code of Ukraine, the Customs Code of Ukraine does not contain the definition of historical cost. But Ukrainian national accounting standard No 9 "Inventory" defines historical cost and it main characteristics [13]. Despite that, the Customs code of Ukraine uses expenses accumulation method (integral parts of goods value) for the purpose of customs payments calculation, although it seems partly chaotic.

It should be noted that the customs value components depend on a customs regime of the foreign trade operation [10]. But we should not consider above mentioned customs regimes as the same as sources of goods arrival, which define historical cost structure in accordance with National accounting standards. There are many serious discrepancies between those definitions.

As for the fours characteristic we should note, that it's almost similar for both categories - customs value and historical cost. The Customs code has strictly detailed procedures of customs control and control of customs value declared by the importer. The customs value must be confirmed with the list of certain documents. It means that customs officer at first checks is declared value of goods the same to the information in the documents. This procedure characterizes the process of operation control of customs value.

We should also note the post customs control (post-audit) in accordance with customs regulations, that takes place when customs control procedures and customs clearance are finished. This kind of control was found extremely efficient because it ensures sufficient budget incomes by finding flaws in the declared customs value.

Unlike the customs value, historical costs calculation control is performed by company itself and its internal control (audit) divisions. The control is performed, first of all, at the step of initial accounting procedures, and software used by the company determines the method of automatic calculation of historical costs in accordance with National accounting standards. The above mentioned method should be clear and sharp, and it should not depend on the human factor.

External control of historical costs calculation is the competence of tax authorities and other state control authorities. It performs periodically according to current legislation [12].

Customs value calculation methods (as the next characteristic) depend on the customs regime of import. The most common method is the method of the contractual price. National accounting standards do not have any method of historical cost calculation. Nevertheless, we could call the systematic accumulation of its integral parts the simple method of historical costs calculation (table 1).

Historical costs in accordance to National accounting standard No 9 could be of different types, namely purchasing price, cost of production, fair value. The above mentioned standard defines elements of each type depending on the goods arrival source. Meanwhile, during customs procedures in different customs regimes, the Customs Code requires to use the term "customs value".

After a comparative analysis of the customs value and historical costs of goods on their main characteristics, we want to note a number of contradictions that occur in the current business. This is because both values are different and serve different purposes; however, they are closely related. In particular, the historical cost of goods received by the company from foreign sources is the contract value of the goods, which is specified in the specification (invoice), along with the amount of customs duties paid during customs clearance and other necessary and sufficient costs specified in the National accounting standard No 9, which make the products suitable for its intended use [13]. In other words, the components of the historical cost form the customs value of the goods, which subsequently accumulates and will differ from the historical cost.

The norm of the Tax Code, which prescribed determination of value added tax during the sale of goods imported by the company based on the value not less than their customs value, became quite controversial at the time [12]. This statement nullified all efforts to harmonize tax and accounting value of goods. Due to changes in tax legislation since 2015, the customs value category has ceased to appear when determining the VAT tax base for the sale of imported goods. However, it should be noted that the above mentioned rule, realizing the main mission of customs value, contributed to the filling of the state budget due to both subjective and objective factors.

Due to the fact that this fiscal norm has become a priority, the value of the historical cost of goods and compliance with the requirements and recommendations of accounting standards for a certain time was eliminated, because the object of 
value added tax was the customs value of imported goods. This is due to the fact that the amount of the customs value in the vast majority of cases, as practice shows, significantly exceeds the historical cost of imported goods, which leads to the VAT taxation object increase. The point is that during the control procedure of determining the declared customs value, the customs authority has the right to make a decision on its correction. In case of disagreement with this decision, the importing company has the right to release goods for free circulation after payment of customs duties on the basis of the declared customs value and with the mandatory provision of financial guarantees, which creates additional financial problems and bureaucratic obstacles to successful business process and further completion of the foreign trade operation. In addition, the existing methodological framework for the customs value determining contains a substantial list of internal and general rules and guidelines, which serves as a basis for abusive practice and evasion of customs duties during the import of goods into the customs territory of Ukraine and during the export of goods; accordingly, it has a negative effect on the final selling price of the imported goods, which includes VAT.

At the same time, the lack of effective mechanisms to control the correctness of taxation of goods moving across the customs border of Ukraine inevitably leads not only to a reduction in import VAT, excise and other customs payments to the budget, but also to suppress the development of legal production and trade, and the development of the domestic economy at large.

The process of determining the reliable customs value of imported goods deserves the most attention for the customs control purposes.

According to the provisions of Article 49 of the Customs Code of Ukraine, the customs value of goods moving across the customs border of Ukraine is the value of goods used for customs purposes, which is based on the price actually paid or payable for these goods.

Article 50 of the Customs Code of Ukraine stipulates that information on the customs value of goods is used, in particular, for the calculation of customs duties.

The system of the customs value of goods calculation is based on the general principles of customs valuation adopted in international practice. The international legal standard to which Ukrainian customs legislation is based is the agreements on the application of Article VII of the General Agreement on Tariffs and Trade 1994 (GAAT).

According to Part 2 of Article VII of the GAAT, the valuation of imported goods for customs purposes must be based on the actual value of the imported goods on which the duty is calculated, or similar goods and must not be based on the value of goods of national origin or arbitrary or fictitious value.

In accordance with Part 1 of Article 51 of the Customs Code of Ukraine, the customs value of goods moving across the customs border of Ukraine is determined by the declarant in accordance with the provisions of this Code.

The Customs Code clearly establishes the condition under which the body implementing customs control and customs clearance has the right to request additional documents and refusal of customs clearance at the declared customs value of goods by the first method (contract price) - if the customs does not agree with the declared customs value of the goods moving across the state border, the latter has the right to refuse to agree on the value declared by the declarant. Due to its mass nature, this issue is currently the subject of most lawsuits that arise between foreign trade subjects and the customs authorities. Analyzing the case law on these issues, we must note that in the vast majority of cases, the courts rule in favor of importers, the main reason for which is the lack of admissible evidence of the impossibility of using the first method of customs value calculation.

For example, the Supreme Court of Ukraine in its decision dated 21.12.2018 in the case No 815/228/17 concluded that the presence in the information databases of the customs authority of information that in previous periods similar goods were cleared through customs, indicating a higher customs value of any way does not prove the incorrectness of its calculation by the plaintiff, because the customs value depends on a number of circumstances and is determined in each case.

In accordance with Part 2 of Article 58 of the Customs Code of Ukraine, the method of calculation the customs value of goods at the price of the contract (agreement) on imported goods is not used if the information used by the declarant or his authorized person is not documented or quantified and / or missing one of the components of the customs value, which is mandatory in its calculation. In this case, part 3 of Article 53 of the Customs Code of Ukraine stipulates that if the documents referred to in part 2 of this article contain discrepancies, have signs of forgery or do not contain all the information confirming the numerical values of the customs value of goods or information on the price actually paid or payable for these goods, the declarant or the person authorized by him at the written request of the customs is obliged to provide (if any) additional documents within 10 calendar days.

Based on the analysis of the above mentioned rules, the courts conclude that the law clearly describes the condition under which customs has the right to exercise such powers as requesting additional documents and refusal of customs clearance at the declared customs value of goods. Such an imperative condition is the existence of reasonable doubts about the correctness of the customs value of goods specified by the declarant.

According to the courts, doubts are justified if the documents contain discrepancies, have signs of forgery or do not contain all the information confirming the numerical values of the components of the customs value of goods or information on the price actually paid or payable for these goods. Therefore, according to the courts, the provisions of these articles oblige the customs to indicate the specific circumstances that raised doubts, the reasons for the impossibility of verification on the basis of documents provided by the declarant, as well as justify the need to verify disputed 
information and indicate documents that may remove doubts reliability. Having established the absence of sufficient information confirming the declared customs value of goods, the customs authority must indicate which components of the customs value of goods are unconfirmed, why it is impossible to establish these components from the submitted documents and which documents are needed to confirm a component.

An appearance of risk profiles in the automated risk analysis and management system and the existence of information from the customs authority that identical or similar goods have been cleared through customs by other persons at a higher customs value, unless there are other legal grounds for requesting additional documents, cannot be grounds for refusal to accept the customs value of goods declared by the declarant at the contract price.

It is true that information from the databases of the State Customs Service of Ukraine is only ancillary information in making of appropriate decisions by the customs and for objective reasons cannot contain all information concerning foreign trade activity, goods and conditions of sale, so such data cannot be more important than the primary documents provided by the declarant about the goods. The discrepancy between the level of the declared customs value of the goods and the level of customs value of identical or similar goods, customs clearance of which has already been carried out, is not conclusive evidence to confirm the conclusion of inaccuracy of data on the declared customs value of goods.

In this case, according to the courts, the customs authorities need to study the documents on the supply of goods in order to establish evidence that confirms the doubts about the correctness of the customs value of goods calculation. The customs authority is obliged to prove the validity of this doubt, as the law connects the possibility of requesting additional documents from the declarant with this circumstance and gives the right to take actions aimed at adjusting the customs value of the goods. Thus, the main reason that leads to decisions not in favor of customs is the lack of specific grounds for requesting additional documents.

In accordance with the foregoing, we can conclude that any further harmonization of customs and initial value of imported goods is not possible until the legislative settlement of problematic issues of customs value adjustment by the State Customs Service of Ukraine. It is clear that in conditions when the customs authority arbitrarily adjusts the customs value of the goods to a greater extent not on the basis of the importer's documents, but on the basis of its own empirical data concerning the import of similar goods by other companies, such adjusted customs value will always differ from the historical cost, calculated in accordance with the accounting rules.

This problem can be resolved only by amending the Customs Code of Ukraine, which would limit the grounds according to which the customs authority may adjust the customs value of goods in the presence of documented differences in the customs value of goods calculation by the declarant.

Based on the analysis, it is possible to identify the main problems that prevent further harmonization of accounting and taxation of foreign economic activity in Ukraine. In our opinion, the restraining factors are the imperfection of the current customs legislation, as well as the established practice of customs authorities. Such non-regulation leads to distortions in the determination of the customs value of goods due to its adjustment by the customs authorities, which causes significant deviations of the customs value and historical cost of imported goods.

Thus, the presence of problems in the convergence of the concepts of customs value and historical cost is caused by a set of reasons of financial and economic nature. At the same time, the priority areas in solving the above mentioned problems are improving customs legislation, simplifying customs control procedures, forming effective models of customs risk management and introducing strict liability for violations of customs legislation by both importers and employees of the State Customs Service of Ukraine. In this works innovative technologies methods, many web sources were used for solving problem.

\section{REFERENCES}

1. Berezhniuk I.G. (2013). Aktual'ni pytannya teoriyi ta praktyky mytnoyi spravy. [Current issues of theory and practice of customs] / I.G. Berezhniuk // Monograph. Mytna sprava v Ukrayini. Tom 21 - Customs in Ukraine. Volume 21. Khmelnytsky: PE Melnyk A.A. - 428 pages [in Ukrainian].

2. Bilets'ka L.M. (2010) Mytna vartist' - terra incognita v ukrayins'komu zakonodavstvi [Customs value - terra incognita in Ukrainian legislation] / L.M. Bilets'ka // Visnyk Verkhovnoho Sudu Ukrayiny - Bulletin of the Supreme Court of Ukraine 3 (115). - p. 35-38 [in Ukrainian]

3. Butynets F.F., Zhyhley I.V., Parkhomenko V.M. (2003) Oblik i analiz zovnishn'oekonomichnoyi diyal'nosti [Accounting and analysis of foreign economic activity] / F.F. Butynets, I.V. Zhyhley, V.M. Parkhomenko // Navchal'nyy posibnyk - Textbook. Zhytomyr: PP Ruta [in Ukrainian].

4. Voytov S.G. (2010) Mytna vartist' yak ekonomichna katehoriya [Customs value as an economic category] / S.G. Voytov // Mytna polityka ta aktual'ni problemy ekonomichnoyi bezpeky Ukrayiny na suchasnomu etapi: tezy III mizhnarodnoyi naukovo-praktychnoyi konferentsiyi molodykh vchenykh. - Dnipropetrovs'k: Akademiya mytnoyi sluzhby Ukrayiny. - Customs policy and current problems of economic security of Ukraine at the present stage: abstracts of the III International Scientific and Practical Conference of Young Scientists. Dnepropetrovsk: Academy of Customs Service of Ukraine. - p. 25-26 [in Ukrainian]

5. Zhurakovskaya E. (2012) Importni operatsiyi: kontrol', oblik ta opodatkuvannya [Import operations: control, accounting and taxation] / E. Zhurakovskaya. // [Electronic source] - access mode: https://uteka.ua/ua/publication/Importnye. 
6. Law of Ukraine Pro zovnishn'oekonomichnu diyal'nist' [On Foreign Economic Activity] // [Electronic source] access mode: http://zakon.rada.gov.ua/cgibin/laws/main.cgi?nreg=959-12. [in Ukrainian]

7. Kalens'kyy M.M., Voytseshchuk A.D., Berezhnyuk I.H. (2005) Mytna vartist' importnykh tovariv [Customs value of imported goods] / M.M. Kalens'kyy, A.D. Voytseshchuk, I.H. Berezhnyuk // Monograph - K. : 2005. 224 p. [in Ukrainian]

8. Koblyanska H.U. (2009) Oblik ta audit eksportno-importnykh operatsii pidpryiemstv [Accounting and audit of export and import operations of the enterprises] / H.U. Koblyanska - [Electronic source] - access mode: http://www.nbuv.gov.ua/ard/2009/09kgyiop.zip. [in Ukrainian]

9. Koval O.D., Balabaykina N.V. (2010) Metodyka bukhhalters'koho obliku eksportno-importnykh operatsiy [Methods of accounting for export-import operations] / O.D. Koval, N.V. Balabaykina // Bukhhalters'kyy oblik i audit - Accounting and Auditing. No 4. - p. 31-35 [in Ukrainian]

10. The Customs Code of Ukraine No 4495-VI dd. 13.03.2012 // [Electronic source] - access mode: http://zakon2.rada.gov.ua/laws/show/4495-17/ed20120313. [in Ukrainian]

11. Order of the SFS of Ukraine. Pro zatverdzhennya Metodychnykh rekomendatsiy shchodo roboty posadovykh osib orhaniv dokhodiv i zboriv $z$ analizu, vyyavlennya ta otsinky ryzykiv pry zdiysnenni kontrolyu za pravyl'nistyu vyznachennya mytnoyi vartosti tovariv, yaki peremishchuyut'sya cherez mytnyy kordon Ukrayiny [On approval of Guidelines for the work of officials of the bodies of revenues and fees for analysis, identification and assessment of risks in monitoring the correctness of determining the customs value of goods moving across the customs border] // [Electronic source] - access mode: http://sfs.gov.ua/yuridichnim-osobam/ podatkoviykontrol/nakazi/print-66340.html. [in Ukrainian]

12. The Tax Code of Ukraine No 2755-VI dd. 02.12.2010. [Electronic source] - access mode: http://zakon4. rada. gov. ua/laws/show/2755-17. [in Ukrainian]

13. Regulation (standard) of accounting No 9 "Inventory", approved by order of the Ministry of Finance of Ukraine Положення No 246 dd. 20.10.1999. (зі змінами та доповненнями) // [Electronic source] - access mode: http://kodeksy.com.Ua/buh/psbo/9.htm. [in Ukrainian]

14. Regulation (standard) of accounting No 21 Impact of changes in exchange rates approved by the order of the Ministry of Finance of Ukraine No 193 dd. 10.08.2000 // [Electronic source] - access mode: http://zakon.rada.gov.ua/cgibin/laws/main.cgi?nreg=z0515- 00. [in Ukrainian]

15. Tereshchenko S.S., Hablo G.O. (2011) Mytna vartist': suchasnyy stan, problemy ta shlyakhy rozv"yazannya. [Customs value: current status, problems and solutions] /S.S. Tereshchenko, G.O. Hablo // [Electronic source] access mode: http://irbis-nbuv.gov.ua. bl_posiv_2011.pdf [in Ukrainian]

16. Tereshchenko S. (2010) Tsina ta vartist' u sferi mytnoho rehulyuvannya [Price and cost in the field of customs regulation] / S. Tereshchenko. // Visnyk CNTU - Bulletin of CUNTU. - No 3-p. 40-48. [in Ukrainian]

17. Robert Grosse International business. Theory and managerial applications / Robert Grosse, Duane Kujawa. Irwin. Homewood, Illinois, 1992. - 733 p.

18. EU-Ukraine Association Agreement. Title IV: Trade and Trade-related Matters. 356 p. 


\title{
CREATURE OF EFFECTIVE SYSTEMS OF ECONOMIC CONTROL IN HOUSING AND COMMUNAL SERVICES IN CONDITIONS OF TRANSFORMATION OF GENERAL MANAGEMENT PRINCIPLES IN INDUSTRY
}

\author{
${ }^{1}$ Nataliia Holovchenko, ${ }^{2}$ Yevhen Holovchenko \\ ${ }^{1}$ Associate Professor of the Department of Audit and Taxation, PhD of Economics, Central Ukrainian National Technical \\ University, Ukraine. https://orcid.org/0000-0002-9742-1703 \\ ${ }^{2}$ Fourth year student of the Department of Financing, banking and insurance. Kyiv-Mohyla Academy, Ukraine. \\ https://orcid.org/0000-0003-1894-3675 \\ Email: 1natali.holovchenko@gmail.com, 2Jack.holovchenko@gmail.com
}

\begin{abstract}
The purpose of this article is to summarize the main goals and tasks of management in the housing sector, to formulate on their basis the modern management principles in researched industry, as well as to identify the influence of general management principles in the housing sector on building effective systems of economic control at the enterprises of the studied sector.

In the article the aggregative units of general and special objectives and goals of management in the housing sector are systemized. On the basis of this summarizing, general principles of management in the studied industry that should be at the core of building an effective system of economic control, as a function of management, were formulated. It was also systematized the main factors that influence on the systematic and complex management and should be taken into account when constructing effective systems of economic control in the housing sector, with the goal orientation of such systems in providing control in the interests of consumers of utility services.

It was concluded that when using the principles of focus, systematic and complexity to build effective systems of economic control in the housing sector, scientists should apply other than planning-directive, sense. This sense consists on the direction of the management on the needs of consumers of housing and communal services, with maximum consideration of such factors as: the number and structure of consumers of public services; the volumes of consumption of utilities; the organizational-technological peculiarities of performers of housing and communal services.
\end{abstract}

Keywords: housing and utilities sector, housing and communal services, principles of management, the system of economic control.

\section{INTRODUCTION}

The dynamic and depth of the transformational changes, which last from the beginning of the independence of Ukraine in its economy differs a lot for each particular sphere. Considering the sphere, which transformation is the slowest and the most influencing on society, we can mention the control of housing and communal services.

Therefore, the system of transformational Transformations in Housing and Communal Services is required to ensure not only a structural transition from the command-direct to the market model of enterprise management of the studied industry, but also to direct such management in the interests of consumers of housing and communal services. An important element of such transformations of housing, in our opinion, is an effective system of economic control as a function of management.

Analysis of resent researches and publications. Researches on the theme of general principles of governing of the control of housing and communal services were actively studied as with Soviet scientists $[1-4 ; 6 ; 8-9 ; 11-12 ; 14 ; 16]$, as with nowadays researchers $[5 ; 7 ; 13]$. In the same time, the transformation of tasks and principles of management of housing and communal services in the open market circumstances, and the influence of such transformations on the creating of effective informational systems (accounting, regulation, control) were not fully researched by modern domestic scientists.

Main purpose of the article. The purpose of this article is to summarize the main goals and objectives of management in housing, formulating on their basis modern management principles in the industry, as well as disclosing the impact of general management principles in housing on building effective economic control systems in the studied industry.

Results and discussions. Housing and communal services is a special industry that operates to achieve a specific goal - the provision of public goods in the form of housing and communal services to a wide range of individual and collective 
consumers - enterprises and individuals. To achieve this goal in the market of housing and communal services there are certain processes as a result of which such goods are created, redistributed and consumed.

Achievement of the goal of housing directly depends on the effectiveness of management processes that take place in the market of housing and communal services and related to the generation, distribution and consumption of such services. The essence of management as a process, quite correctly, is revealed in the research of Muhin V.I. of the basis of management theory: "Management - the activity of the control subsystem, which consists in the development of control influence and its implementation and is aimed at effectively achieving the goal of the system as a whole" [10, p. 14]. So, in order to effectively achieve the goals of housing and communal services, it is necessary to ensure effective management of the process of providing housing and communal services both at the level of the industry as a whole, as at the level of individual service providers in particular.

Goals and objectives of management in housing should be structurally divided into:

- general goals and objectives of management, which are inherent to any management system and aimed at ensuring the effective implementation of management activities;

- specific goals and objectives of management, due to the sectoral characteristics of housing.

Consideration of features of mechanism of economic relations in housing and communal services testifies about specificity of the studied industry as an object of management. Therefore, it can be argued that the system of management of the sphere is significantly different from other segments of the economy and needs to be specified in terms of basic tasks and principles of management.

Quite correct, in our opinion, generalizations about the specifics of housing and communal services as an object of management expressed Bezlyudov A.I. in his works: "Housing is one of the most complex objects of combined production management" [1, p. 4] and "The diversity of housing and communal services determines the uniqueness and specificity of its management" [2, p. 7].

The specificity of the studied industry determines the specificity of the tasks and principles of management in housing. Speaking about the principles of management, we understand the commonly used definition of management theory - the most general, fundamental rules and recommendations that must be considered and implemented in practice at all levels of management [10, p. 83]. In addition, we are sure that the principles of management directly affect certain management functions (accounting, regulation, control, etc.).

The main and general principles of management in management theory include: scientific; systematic and complexity; the principle of unity in management and collegiality in decision-making; the principle of centralization and decentralization; the principle of proportionality in management; the principle of unity of management; the principle of saving time; the principle of priority of management functions over the structure when creating organizations and vice versa, the priority of structures over management functions in existing organizations; the principle of delegation of powers; the principle of feedback [10, p. 83].

We are sure that in order to apply in housing and communal services, the underlining management principles must take into account the specific nature of the research area. In addition, the principles of management in housing and communal services should be formulated taking into account the transformational changes of the economy, as a result of which there is a global change in model - from the directive to market model of industry management, resulting of changing the main tasks of management. As a result, the structure of tasks and principles of management in housing and communal services we propose to consider as follows (Figure 1).

Special principles of management in housing and communal services should be formed considering specifics of the researched sphere. A separate publication of ours will be devoted to the disclosure of such management principles in housing and communal services. The general principles of management in housing and communal services should be aimed to solve management problems in a transformational economy and are equally fair to other sectors of the national economy. To the general principles of management in housing and communal services we suggest carrying the following two:

1. The principle of purposefulness. Any management activity is aimed at achieving a certain set of goals or solving a specific number of tasks. Goals and objectives of management in housing are formed under the influence of technological and economic features of the industry and are aimed at maximizing the needs of consumers of housing.

Purposeful management in housing and communal services should be provided at each stage of management. Today there is a classic division of housing and communal services into technological and maintenance. On the one hand, the structural separation of technological enterprises of housing and communal services, allows scientists to talk about the technological approach to forming a management system for such enterprises, which involves targeted management at each technological stage of providing (production and sale) of utilities. On the other hand, both maintenance services, and services of complex improvement, and management of housing and communal services as a whole, can be considered as the certain technology divided into stages, procedures on which target managerial influence can be carried out.

In support of this approach, Sadykov, A.S. in his work wrote: "For individual enterprises, the technology of production acts as a determining structural factor. At the same time, at the level of communal services in general, where organizational and production management structures are formed, such a factor is the technology of functioning of branch systems to meet the needs of the city" [14, p. 76]. 


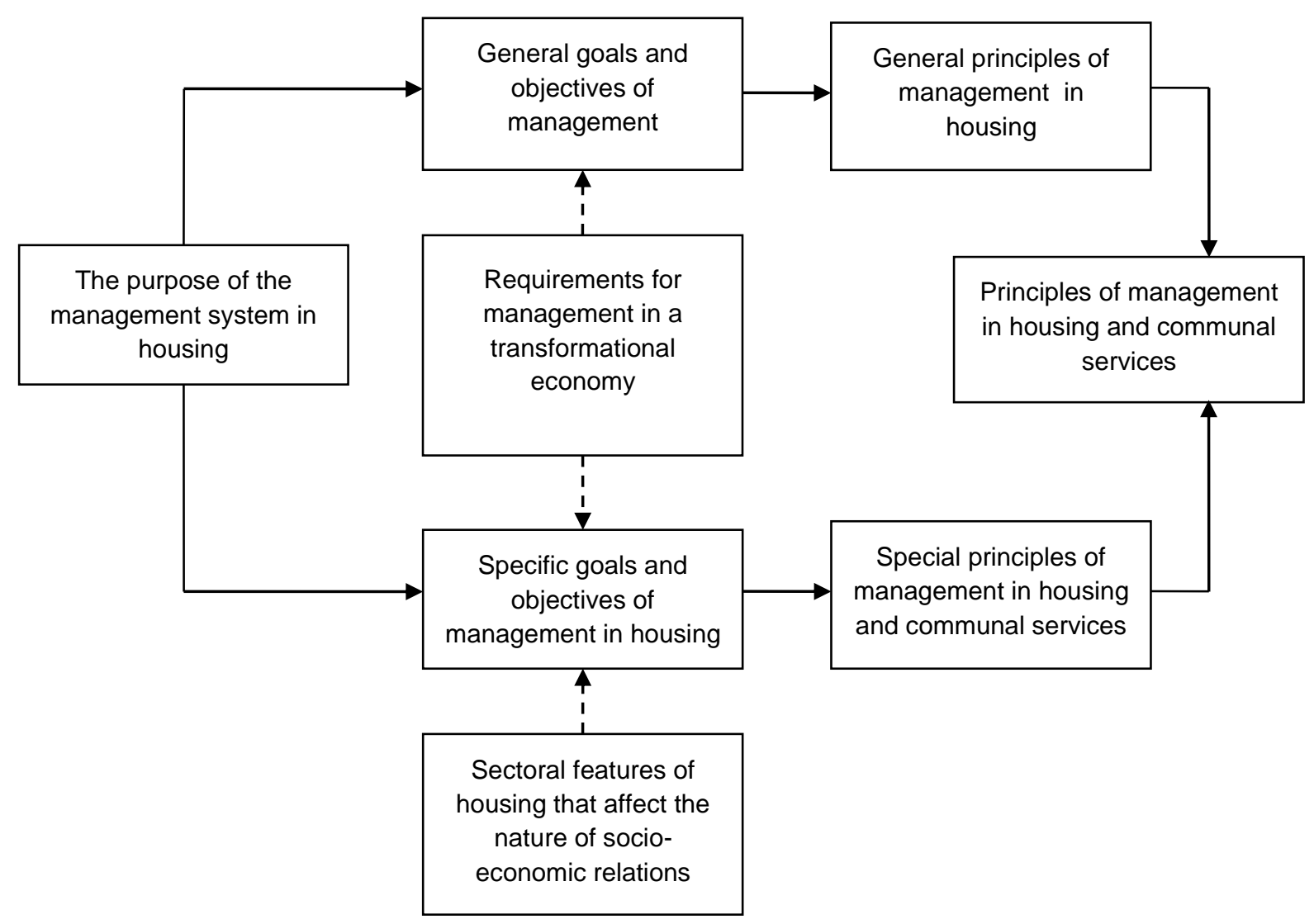

Figure 1 - The structure of tasks and principles of management in housing

Source: developed by the author.

So, the mentioned author quite correctly, in our opinion, described the process of providing any housing and communal services as a certain technology aimed at meeting the needs of specific consumers. Moreover, all stages of the technology of housing and communal services (preparation, production and sale) should also be aimed at these goals.

The use of the principle of purposeful management is one of the basic in the formation of the concept of management of the process of providing housing and communal services in the interests of consumers, as well as in building effective economic control systems that should provide such management with the necessary information.

2. The principle of systematic and complexity. This principle of management in housing is formed as a result, firstly, the definition of the studied industry as a set of sub-sectors united by a common goal - the provision of diverse housing and communal services to a wide range of individual and collective consumers; secondly, the definition of the process of providing housing and communal services from a technological standpoint (as a set of stages, stages, procedures, etc.). To reveal this principle of management in housing, some authors have built a comprehensive management system of housing and communal services on the example of large cities, indirectly understanding that the management of communal services in small towns (villages, settlements) is more simplified. So, the conclusions made of the tasks and principles of systematic and integrated management of housing and communal services of a large city are equally valid for small territorial units.

A.S. Sadykov, defining the communal services of large cities, notes: "The communal services of a large city are a large industry that combines enterprises of urban passenger transport, water, heat, gas and electricity, drainage, sanitation and outdoor lighting of cities, hot water supply, urban development, road and bridge facilities and others "[14, p. 5].

Communal services of a small town (village, settlement) today in many cases can contain only one or two subsectors of communal services, which are typical for a large city. Subsectors of urban passenger transport, outdoor lighting, 
sanitation, etc. are practically not typical for small territorial formations. Instead, the sub-sectors of electricity, gas, and in many cases water supply are typical of the utilities of small towns (villages, settlements).

As a result, communal enterprises of small towns were defined by other authors as small and economically weak [2, p. 9; 6 , p. $5 ; 14$, p. 6], and in their organizational form were considered as part of the communal economy of a large city [14, p. 6-7]. Some authors in general have reduced the study of the specifics of management in the field of housing and communal services excluded to business entities operating in cities [8, p. 18; 12, p. 8].

Exploring the factors that must be considered to ensure the systematic and complex management of public utilities in a large city, A.S. Sadykov includes:

- administrative-territorial significance of the city and population;

- qualitative and quantitative composition of management objects;

- factors of scientific and technological progress (including equipment, technology, use of ACS);

- social and household factors (including quantitative and qualitative composition of consumers; structure of services; volume of services);

- organizational and managerial factors (organizational forms of management, governing bodies, territorial principles of management, sectoral principles of management) [14, p. 14-17].

The need for a comprehensive combination of territorial and sectoral principles of management was noted by Bezlyudov A.I. , who wrote in his work: "In the management system of housing and communal services due to its specificity, the territorial aspect is important. Ensuring the optimal combination of sectoral and territorial management of the economy is one of the pressing issues of planning theory and practice "[2, p. 7].

In our opinion, in a circumstance of transformation of economy, the systemic and comprehensive management of housing and communal services in general and its functions, in particular, should be provided considering another set of factors:

- quantity and structure of management objects;

- quantity and structure of utility consumers;

- volumes of consumption of communal services;

- organizational and technological features of performers (manufacturers) of housing and communal services.

Organizational and managerial factors, as well as the administrative importance of a particular city (village, town) in the formation of an effective system of public utilities management have no significant impact, in our opinion, today.

A.S. Sadykov comes to similar conclusions. He is noting that the features of the management of the studied industry change depending on the number and composition of management facilities and technology of customer service [14, $p$. 19].

All the factors mentioned by us have an impact on the formation of a comprehensive management system of housing and communal services and at the micro level (at the level of a specific executor (manufacturer) of housing and communal services). At the same time, the factor of organizational and technological features of executors (producers) of housing and communal services comes to the first place when forming the management system at the micro level.

The main direction of improvement of management systems in housing and communal services at the micro level, considering the principle of creating a system and complexity in the Soviet period was considered the consolidation of economic entities (city and regional production associations, production departments, trusts, etc.). It was proposed to create an association of public utilities on the basis of territorial and sectoral characteristics [2, p. 46-47; 4, p. 18-21; 12, p. 22].

For example, analyzing the organizational structure and efficiency of management of a particular enterprise of municipal utilities Feinberg A.I. and Krupitsky M.L. note: "The inclusion of a utility company as a shop in the city or regional association allows to reduce management costs and provide the economy with more qualified engineering and technical personnel" [16, p. 19]. Dzhun B.M. in addition to the problems of staffing of small housing and communal services, emphasizes the impossibility of concentrating on these enterprises the necessary funds for the introduction of new equipment and modernization of production [6, p. 6].

Proposals for the consolidation of housing and communal services were made by other authors, who in Soviet times widely promoted the idea of industrial associations of public utilities (including industrial energy associations) [1, p. 74; 6 , p. $9 ; 8$, p. $22 ; 11$, p. $183 ; 12$, p. 25] and trusts [3, p. 39; 14, p. 5]. At the same time, it was proposed to consolidate into production associations on the basis of production and technological cooperation, and into trusts and production departments - on the basis of rational service areas [4, p. 18; 14, p. 85]. Approaches to horizontal (by the same type of enterprises in the industry) and vertical (by the connection of technological processes) association of housing and communal enterprises were studied separately [2, p. 48].

The idea of consolidation (unification) of enterprises in the industry was also proposed for implementation in the field of housing and adjacent areas [9, p. 78-79], which shows the popularity of this approach in the directive model of housing and communal services.

Due to the long period of consolidation of public utilities (associations and trusts) in the Soviet scientific literature, much attention was paid to the system and complexity of management of the utility in general and its structural units in particular. In the terminological base of the Soviet times, the separation of management of separate structural subdivisions of the communal association is fixed as "internal self-financing". To regulate the internal self-sufficiency in the associations 
of public utilities, the authors made appropriate proposals for the formation of standard provisions (other documents of an administrative nature).

Modern domestic scientists, in particular Zapatrina, I.V., also emphasize the greater efficiency of large-scale producers of housing and communal services. In her work she wrote: "Experience has shown that large regional enterprises of district heating, water supply and sewerage are more viable than small ones, as economies of scale can solve serious problems related to the implementation of effective management, preparation and implementation of strategic development programs. , attracting borrowed funds without a significant increase in the cost of services provided "[7, p. 87-88].

Conclusions and further researches directions. In this publication we have proved that today, when using the principles of purposefulness, systematization and complexity to build effective systems of economic control in housing and communal services, scientists should lay down another, different from the directive, content. This content was made, to direct the management to the needs of consumers of housing and communal services, with maximum consideration of such factors as: the quantity and structure of consumers of communal services; volumes of consumption of communal services; organizational and technological features of housing and communal services.

On the other hand, a crucial condition for creating of effective systems of economic control in housing is the formulation of special goals and objectives of management, which follow from the sectoral characteristics of housing, which significantly affect the nature of socio-economic relations. Our separate publication will be devoted to the study of special management principles in housing and communal services and their impact on the construction of effective systems of economic control in the industry.

\section{REFERENCES}

1. Bezlyudov A.I. (1990). Zhilishchno-kommunalnoye khozyaystvo: problemy upravleniya [Housing and communal services: problems of management]. Moskva: Stroyizdat [in Russian].

2. Bezlyudov A.I. (1983). Tsentralizovannoye planirovaniye i upravleniye zhilishchno-kommunalnym khozyaystvom [Centralized planning and management of housing and communal services]. Moskva: Stroyizdat [in Russian].

3. Broner, D.L., Krupitskiy, M.L., Filatov, N.L. (1972). Ekonomika i statistika zhilishchnogo i kommunalnogo khozyaystva [Economics and statistics of housing and communal services]. Moskva: Vysshaya shkola [in Russian].

4. Goltsman, L.N. (1966). Ekonomika kommunalnogo khozyaystva, uslugi, tarify [Economics of public utilities, services, tariffs]. Moskva: Ekonomika [in Russian].

5. Hura, N.O. (2006). Oblik u zhytlovo-komunalnomu hospodarstvi: teoriia i praktyka [Accounting in the housing sector: theory and practice]. Kyiv: Znannia [in Ukrainian].

6. Dzhun B.M. (1979). Effektivnost ekonomicheskogo stimulirovaniya kommunalnogo khozyaystva [The effectiveness of economic stimulation of utilities]. Kyiv: Budivelnik [in Russian].

7. Zapatrina, I.V. (2010). Zhilishchno-kommunalnaya infrastruktura: reformy i sistema ikh finansovogo obespecheniya [Housing and communal infrastructure: reforms and system of their financial support]. Kyiv: NAN Ukrainy; Institut ekonomiki i prognozirovaniya [in Russian].

8. Kaspin, V.I. (1990). Planirovanie razvitiya zhilishchno-kommunalnogo khozyaystva [Planning of development of housing and communal services]. Moskva: Stroyizdat [in Russian].

9. Kuzovchikov V.M. (1989). Zhilischnoe hozyaystvo. Puti perestroyki [Housing sector. Ways of adjustment]. Moskva: Stroyizdat [in Russian].

10. Muhin V.I. (2002). Osnovyi teorii upravleniya [The basics of management theory]. Moskva: Ekzamen [in Russian].

11. Ivanov S.I. (1986). Organizatsiya i upravlenie kommunalnyim teploenergeticheskim hozyaystvom [Organization and management of communal heat-and-power business]. Moskva: Stroyizdat [in Russian].

12. Orlova R.I. (1988). Ekonomika zhilishchno-kommunalnogo khozyaystva [The economy of housing and communal services]. Moskva: Stroyizdat [in Russian].

13. Instytut sotsialno-ekonomichnykh stratehii. (2012). Promizhnyi zvit pro naukovo-doslidnu robotu na temu "Doslidzhennia chynnoho zakonodavstva Ukrainy u zhytlovo-komunalnii sferi ta pidhotovka propozytsii shchodo yoho vdoskonalennia z metoiu zabezpechennia derehuliatsii ta prozorosti shliakhom rozroblennia yedynoho unifikovanoho bazovoho zakonoproektu v zhytlovo-komunalnomu hospodarstvi" [Interim report on research work on "Study of the current legislation in the housing sector and preparation of proposals for its improvement with the aim of securing deregulation and transparency through the development of a single unified underlying bill in housing and communal services"]. http://www.ises.com.ua. Retrieved from http://www.ises.com.ua/ Zvit_Konzepsia_LAST.pdf [in Ukrainian].

14. Sadykov, A.S., Smirnov, V.A., Minasyan, V.A. (1987). Organizatsiya upravleniya kommunalnym khozyaystvom krupnogo goroda [Organization of management of municipal services of a big city]. Moskva: Stroyizdat [in Russian].

15. Usach B.F. (2008). Kontrol i reviziya [The control and audit]. Kyiv: Znannia-Pres [in Ukrainian]. 
16. Faynberg A.I (1981). Analiz hozyaystvennoy deyatelnosti predpriyatiy i organizatsiy zhilischno-kommunalnogo hozyaystva [Analysis of economic activity of enterprises and organizations of housing and communal services]. Moskva: Stroyizdat [in Russian]. 


\title{
INFORMATION SUPPORTING SYSTEM ABOUT TAX CAPACITY OF A COMPANY AND ITS EFFICIENCY: PRINCIPLES OF FORMATION AND EVALUATION
}

\author{
${ }^{1}$ Halyna Kuzmenko, ${ }^{2}$ Nataliia Shalimova, ${ }^{3}$ Alla Lysenko \\ ${ }^{1}$ Associate Professor of the Department of Audit, Accounting and Taxation, PhD of Economics, Central Ukrainian National \\ Technical University, Kropyvnytskyi, Ukraine. https://orcid.org/0000-0003-2792-1320 \\ ${ }^{2}$ Dean of Accounting and Finance Faculty, Doctor of Economics, Professor, Central Ukrainian National Technical \\ University, Kropyvnytskyi, Ukraine. http://orcid.org/0000-0001-7564-4343 \\ ${ }^{3}$ Associate Professor of the Department of Audit, Accounting and Taxation, PhD of Economics. Central Ukrainian National \\ Technical University, Kropyvnytskyi, Ukraine. http://orcid.org/0000-0001-8193-4267 \\ Email: 19alina.leda@gmail.com, 2nataliia.shalimova@gmail.com,3lysenkoalla2010@ukr.net
}

\begin{abstract}
The principles of forming the system of information about tax capacity are grouped and the directions of activity of the enterprise are identified, in view of which it is expedient to establish criteria for assessing its efficiency. The formation of information about tax capacity of an enterprise should occur not chaotically, but according to certain principles. The lists of basic principles (unity, objectivity, competence, probability and periodicity) and additional principles (dynamism, rationality, conformity, control) have been substantiated. The system of indicators and criteria of the formalized expression of efficiency is offered. The list of indicators made it possible to build the system (vector) of criteria requirements to ensure the effectiveness of information about the tax capacity of a business entity. It has been proved that in assessing the effectiveness of the information supporting system on tax capacity of the entity, the impact of time and cost criteria, as well as other non-measurable parameters should be taken into account. The proposed approach to assessing the effectiveness of the current information supporting system on the taxpayer's capacity will allow assessing alternative information systems in terms of the effectiveness of their implementation.
\end{abstract}

Keywords: information supporting system; taxation; tax capacity; efficiency; principles; criteria; assessment; evaluation

\section{INTRODUCTION}

At each stage of the development of society, there is a need for reliable and sufficient information and its systematization should be carried out in accordance with the relevant principles. Any information system is closely connected both with systems of preservation and issuance of information, as well as with systems providing information exchange. No exception is the information system about tax capacity of a company. By its structure, it is diverse, formed by a "cumulative principle" and encompasses a set of tools and methods that allow users to collect, store, transmit and process the selected information.

In the generalized sense, the system of information about tax capacity of a company is the process of continuous, purposeful obtaining of information necessary for the planning of tax payments and making management decisions at the stages of tax management. The economically grounded assessment of tax capacity of the company depends on the completeness, reliability, timeliness and effectiveness of the information support of the tax process and planning of the amount of tax payments. In its turn, taking into account tax capacity of specific economic entities and the quality of its assessment, factual and expected levels of tax payments at the micro level, as well as tax revenues at the regional and national levels are formed.

Thus, there is a need to develop a clear grading of the principles for creating the system of information on tax capacity of a company, as well as criteria for assessing its effectiveness.

Analysis of recent researches and publications. There was no consensus among scientists about the definition of the essence of tax capacity, the assessment of effectiveness of the use of information systems, grading the principles of the formation of the system of information about tax capacity of economic entities. On the basis of the generalization of the scientific approaches it can be concluded that tax capacity of a business entity is appropriate to consider as a part of the financial resources that represent the potentially possible sum of tax bases, which is the basis for the calculation of the entire number of taxes and compulsory payments in accordance with the current tax legislation. Investigating the interpretation of this concept by various authors, its classification characteristics were revealed, depending on the sources of formation, tax base and costs.

The system of information on tax capacity of a company is based on general principles of system science and a significant contribution to the study was made by D. B. Gelashvili [1], Zade L.A. [2], Mozhovyi D.P. [1], Nalimov V.V. [3], Rosenberg G.S. [1; 4], Fleishman B.S. [5], Forrester D. [6]. Identification of the principles is carried out in accordance with the 
systematic approach and taking into account the existence of different levels of management (macro environment, microeconomic business environment, strategic and tactical level). However, the scope of their application in relation to the component "tax capacity of a company" is not yet sufficiently investigated and needs further study.

The notion of "capacity" in economic literature is considered from the point of view of general and functional approaches. In particular, the existing approaches to the formation of the information on tax capacity are considered in the works of Zakhozhay V.B., Ivanov Yu.B., Lytvynenko Ya.V. and other scholars [7; 8]. However, sharing the opinions of Gudzinskyi O.D., Sudomyr S.M., Hurenko T.O. [9, p. 8] it should be noted that the economic literature does not sufficiently disclose the qualitative characteristics of the capacity and its potential advantages for ensuring the dynamic development of enterprises.

The problems of efficiency of using information systems were investigated by Vyshnevskyi V.P. [10], Voronkova A.E. [11], Matviychuk A.V. [12], Pysarchuk O.O. [13], Steshenko S.G. [10] and other scholars. At the same time, the methodological aspects of assessing the effectiveness of the system of information on tax capacity of the enterprise in the economic literature is not given due attention.

It should be highlighted that scientists do not pay enough attention to the process of planning tax payments at the enterprise level, practically does not focus on the gradation of the principles of the formation of the information system on tax capacity of economic entities, the development of approaches to assess the effectiveness of the information system on tax capacity, the development of a tax passport a business entity as an important tool of ensuring control over the correctness of calculation and payment of taxes. There was no comprehensive analysis of the existing methods for assessing the effectiveness of the information system on tax capacity. In connection with this, a problem arose about the systematization of the principles of information formation about tax capacity of economic entities, the use of financial and non-financial methods for assessing the effectiveness, determining the scope of their use in modern economic conditions.

Main purpose of the article. The objective of the article is the gradation of the principles for the formation of the system of information about tax capacity of a company, grounding of the scope of application of financial and non-financial methods for assessing the efficiency of this system.

Results and discussions. The specificity of the systematic approach is that the objective of the study is to investigate the patterns and mechanisms of the formation of a complex object which is formed by certain components. Particular attention is paid to the variety of internal and external relations of the system, in the process of combining basic concepts into a single theoretical scheme, which makes it possible to identify the essence of the system's integrity.

The information system is an obligatory part of the process of organization of management of tax activities at the enterprise. The modern information system for organizing tax activities at the entity level is interrelated with a set of information data, equipment, software, staff, standards, procedures for the collection, processing, storage, provision of information in accordance with requirements arising from the activity of the enterprise.

The implementation of qualitative changes in the approaches to determine tax capacity of an entity is not possible without focusing on automation and informatization of routine accounting processes, creation of a single information database. We believe that it is advisable to implement the decision-making support system in the tax burden management system in two stages. At the first stage, it is necessary to automate the existing operational tasks which will ensure faster and more qualitative performance and partially relieve the staff of excessive information overloads. At the same time, the implementation of this phase will be accompanied by the accumulation of the necessary information for the qualitative analysis. By reducing the complexity of the formation and use of information resources, increasing their reliability and efficiency in the process of collecting, processing, storing and transmitting information, the next stage may addressed and solve new tasks that require their solution. Information technologies ensure the unification of informal human capabilities and the formal possibilities of computer processing of information.

It should be noted that the study of the essence of the systems and the principles of their functioning were studied in the works of foreign and national scientists. So, in the book "Planning of the Future Corporation" Akoff R. considers the system as a unit that influences the behaviour of each element. According to the scientist, the systematic approach manifests itself in: the identification of the system, part of which is an object that interests the researcher; explaining the behaviour or properties of the whole; explaining the behaviour or properties of an object that is interesting to the researcher in terms of its role or functions in general [14, p. 170-199]. Kustovska O.V. in the work "Methodology of the systematic approach and scientific research" considers the systematic approach as "one of the main directions of the methodology of special scientific knowledge and social practice, the purpose and tasks of which consist in the research of certain objects as complex systems" [15, p. 5], and under the principles of a systematic approach means "general provisions that reflect the attitude abstracted from the specific content of scientific and applied problems" [15, p. 10].

The principle as a concept is the basic rules, laws and requirements. The combination of basic scientific principles of the formation and development of the information system (flexibility, complexity, optimality, efficiency, effectiveness) contains basic requirements for the construction of the system, based on the system approach to management, taking into account the provisions of the theory of management and development.

Among the principles of systems science, we can distinguish several basic principles: 
- the principle of hierarchical organization (or the principle of integrative levels) (Odum, 1975) [16]. This principle is very useful in the study of complex systems and allows establishing a subordination to each other, both natural and artificial systems;

- the principle of incompatibility (Zade L. A., 1974). The essence of the principle manifests itself in the following: the more deeply the real complex system is analyzed, the less certain our judgments about its behaviour. That is, the complexity of the system and the accuracy with which it can be analyzed are related reciprocally. The constructed system should be simple so that it can be explored by available means. On the other hand, as a result of all simplifications, it should not lose its essence [2, p. 7];

- the principle of counter-intuitive behaviour (Forrester D., 1974). This principle is manifested in the fact that it is practically impossible to give a satisfactory prediction of the behaviour of a complex system over a sufficiently large period of time, based only on their own experience and intuition, since intuition comes from the presence of simple systems, the connection of which elements are almost always able to trace. However, the complex system responds to impact in a completely different way than it is intuitively expected. This is the contingent behaviour of the complex system [1, p. 94];

- the principle of multiplicity of models (V.V. Nalimov, 1971) [3]. To explain and predict the structure and behaviour of the complex system, it is expedient to construct several models. In this case, it is possible to build a lot of models, different methods of construction and sources of information used (statistical, simulation, verbal, etc.) [1, p. 94-95].

In addition, scientists distinguish the principle of feasibility, the principle of formation of laws, the principle of recurrent explanation, the principle of minimum and maximum structure of models $[1,5]$.

Typically, the principles are presented simply by enumerating, or through the allocation of classification groups with the disclosure of their essence. Scientific literature offers different classifications of principles. Thus, D.K. Shevchenko distributes principles on general (which reflect basic rules and requirements for the formation of systems) and specific (specific rules for the management of specific target systems) [17, p. 90]. Investigating the principles of constructing the theory of developing systems, O.V. Raevneva divides them into universal ones (which reflect the laws of the theory), system-wide (describing the functioning of systems and based on the general theory of systems), specific (which represent the most important points of the theory) and the principles of management of development (considering development as a management process) [18, p. 92].

We believe that one of the important features of the classification of the principles of the formation and development of systems is their division into basic and additional. Accordingly, the system of information on tax capacity of an enterprise should be formed taking into account the following basic principles (Fig. 1).

We consider it expedient to take into account additional principles (dynamism, rationality, conformity, control) which strengthen the action of the basic principles when forming the system of information about tax capacity of an entity. Simultaneous use of the basic and additional principles in the process of development and implementation of management decisions in the field of taxation will facilitate the coherent work of all components of the system and will ensure the effective development of the system as a whole. In addition, modern information technology should ensure: efficiency, reliability, quality of information; a comprehensive statistical analysis of economic indicators of a taxpayer's activity based on data from tax, financial and statistical reporting; introduction of electronic reporting and e-auditing; the possibility of constructing an integrated statistical base; assessment of tax capacity and tax burden on taxpayers.

The assessment of the effectiveness of the current system of information about the taxpayer's potential should be based on the principles of systems science, objectivity, dynamism, continuity, optimality and constructiveness. The most reasonable result can be obtained by simultaneously assessing tax capacity of an enterprise by different methods and choosing the basis of their actual characteristics. Taking into account that tax capacity of an entity and the tax burden indicators depend to a large extent on the results of its financial and economic activity, we suggest using a combination of economic and statistical research methods in the process of assessing the information.

The fundamental approaches to assessing the capacity components of an entity are covered in the works [7, 10, 11]. However, it should be noted that in the national economic science there is no clearly developed approach to the selection of criteria for assessing the effectiveness of the current system of information about tax capacity of a business entity. In our opinion, the quantitative assessment of the established system of information about tax capacity should be based on the results of preliminary assessment of the economic, production, innovation, financial, marketing, managerial and motivational capacity (potential) of the entity. It is from these components to a large extent the tax capacity of the company depends on. 
Basic principles of the formation of information system on tax capacity of a company

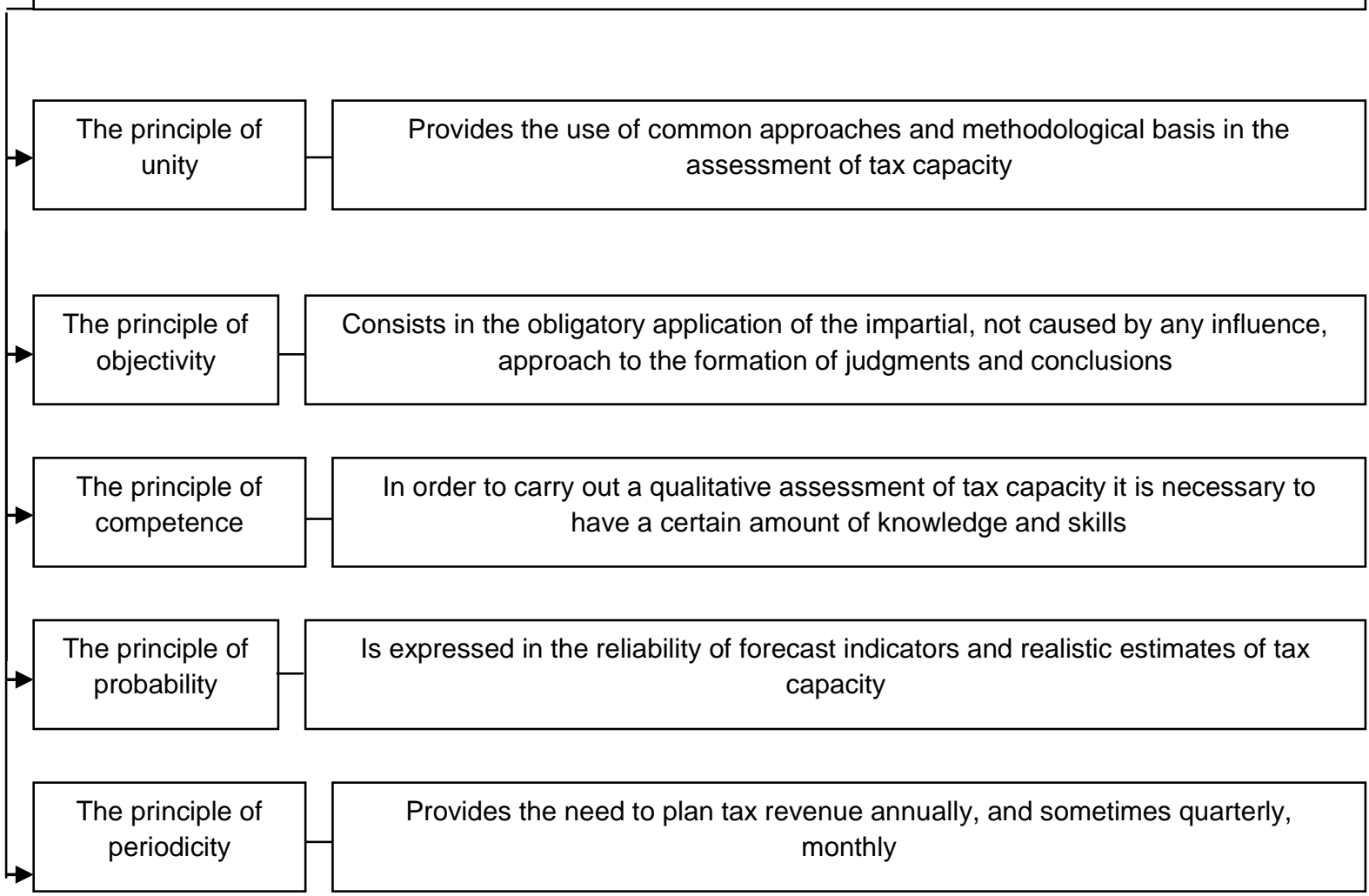

Figure 1. Basic principles of formation the information supporting system about tax capacity of a business entity

Thus, the production potential of an enterprise is characterized by the volume of manufactured products (works, services), production capacity and efficiency of the use of production resources, the payback period and activity of the enterprise in the market. A generalized assessment of the production potential is appropriate to determine as the ratio of the volume of production of the corresponding type of product in a cost measure to the capacity of the corresponding national or world market for products of this type.

The innovative potential of an entity can be characterized as a variety of indicators, such as sales volumes, consumer product properties, and the economy of norms and standards. The assessment of the change in the innovation potential is determined by the ratio of the actual innovation potential to its predicted level. In addition, the assessment of the growth of the level of the parameter of a certain type of product (work, services) in the innovation direction, the degree of readiness for the introduction of the innovation direction for the given products (work, services), the share of certain types of products (work, services) in sales volume of the enterprises and number of types of manufactured products are all taken into account.

A generalized assessment of the financial potential of an enterprise is carried out using the indicator of capital intensity of labour which is calculated by the ratio of the value of working capital, accumulated depreciation and investment accumulation to the number of employees.

Marketing potential is characterized by the productivity of the marketing service of the enterprise, which is determined by the level of reliability of research and recommendations conducted by this service. The criterion of reliability is calculated as the ratio of the actual share of the company in the market to the forecasted share of products (work, services) of the company in the market, determined by the marketing service.

Management potential is characterized by the efficiency of the management team and can be assessed by calculating the ratio of growth rates of production (work, services) of the enterprise to the average industry growth rates of production. Assessment of the motivational potential is determined by the productivity of labour and in the generalized version can be implemented using the ratio of actual income of the enterprise on one employee to the average industry income of the employee.

Consequently, the formation of criteria for assessing the information supporting system on tax capacity should be implemented taking into account the directions of the activity of the enterprise (Figure 2). 
The volume and the structure $o$ the accrued and paid taxes and fees are studied, the dynamics of changes in the tax burden on the entity, the volume and structure of capital, its value, profitability, financial position and solvency of the enterprise, the volume and composition of working capital and its use, the duration of the operational cycle, structure and directions of the use of financial resources are also studied.

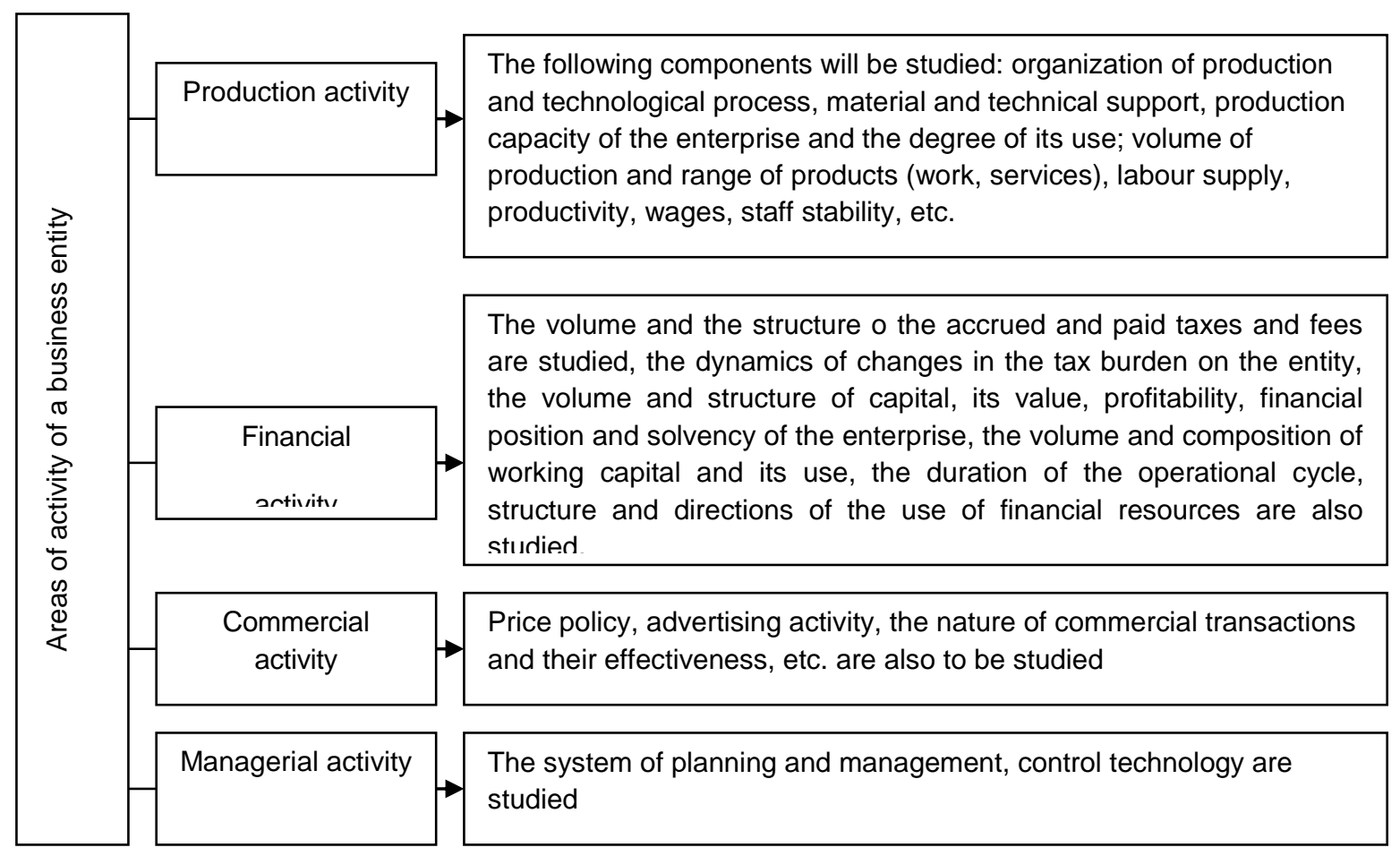

Figure 2. Areas of activity of an entity, on the basis of which it is expedient to form criteria for assessing the efficiency of the information system about its tax capacity

The results of the assessment of the above-mentioned components of the capacity of the enterprise and the features of its market environment will allow making quantitative comparison of the elements that form competitive potential, and therefore determine tax capacity of the entity.

However, it should be noted that capacity assessment is the process that is difficult to formalize. Objectivity and quality of work in this direction are determined by the degree of access to information, its completeness, authenticity, qualifications of evaluating specialists.

Different methods are used to assess tax capacity of an enterprise in the Ukrainian and foreign practices. One of the most important problems is the substantiation of the assessment methods, since it should be based on the definition of the range of indicators that most reveal tax capacity of the enterprise.

Taking into account the parameters of all functional areas of a business entity including the efficiency of the production process, the stability and promising of the enterprise, makes possible through the complex use of qualitative and quantitative analysis.

While conducting an assessment of the information system on tax capacity, the key criterion is efficiency. The purpose of developing criteria for assessing the effectiveness of the current system of information on tax capacity is to help professionals find the necessary solutions, reduce the level of risk, qualify the relationship between the decisions taken and the costs necessary for their realization with their future returns.

In order to provide a formalized criterion of the effectiveness of the information system on tax capacity of the entity, we propose the use of the indicators presented in table 1. 
Table 1 - Indicators providing a formalized expression of the criteria for the effectiveness of the information system on tax capacity of the enterprise

\begin{tabular}{|l|l|}
\hline Indicator & Indicator characteristics \\
\hline 1. Concentration index & $\begin{array}{l}\text { Makes possible to determine the taxes (fees, payments) which have a considerable } \\
\text { relative share in the total amount of charges }\end{array}$ \\
\hline 2. Dispersion index & $\begin{array}{l}\text { The index determines the presence (or absence) of taxes (fees, payments) with the } \\
\text { low amount of payment to the budget }\end{array}$ \\
\hline 3. Erosion index & The index determines the degree of compliance of real tax bases to the factual bases \\
\hline 4. Objectivity index & The index determines the objectivity of the identified tax base \\
\hline
\end{tabular}

To assess the use of information on tax capacity by the enterprise system, we propose the following important indicators: the rate of payment of tax payments (the ratio of actually paid amounts of taxes (fees, payments) to their accrued value); the coefficient of "quality" of payment of taxes (the ratio of actual tax payments, as well as the amount of fines and financial sanctions to the planned amount of payment);

the coefficients of the specific weight of a particular type of taxes (fees, payments) in the total amount of assessed and paid amounts of tax payments;

the coefficient of ratio of growth rates of proceeds from sales, financial results, cost of capital, number of personnel and growth rates of amounts of assessed and paid taxes (fees, payments).

The existing methods for assessing the effectiveness of information systems are classified in three groups: traditional financial techniques; probabilistic methods and tools of qualitative analysis [13]. We offer in assessing the functioning of the information system to take into account that its effectiveness is influenced by time and cost criteria, as well as other non-measurable parameters. In particular, the criteria for influencing the length of working time include the elements of the mechanism for processing the data of accounting and reporting, taking into account both measured and non-measurable factors. Cost criteria reflect expenditure items that can be reduced through the introduction of an electronic information processing system, as well as the costs of its implementation, such as the purchase of the necessary software. The criteria for the reliability of data include those that reduce the degree of uncertainty of information, as well as the amount of errors, increase the accuracy of calculations extend the horizons of forecasting.

In assessing the length of working time, it is necessary to take into account: the degree of duplication of information ( $T d$ ) time for analytical processing of reporting, tracking down and correction of errors (Tp); efficiency of decision-making in the field of taxation ( $\mathrm{Tm})$; time of export of data from accounting programs (Te); the efficiency of updating information for tax analysis and planning $(T u)$.

It is expedient to include in the list of cost criteria: acquisition of forms of reporting and paper documents for filling in information $(\mathrm{Cr})$; personnel engaged in tax planning, in the management of the taxation process of enterprises $(C p)$; penalties (Cs).

The reliability of data is characterized by the following criteria: the level of automation of accounting and analytical work $(D a)$; time period of tax analysis and planning (Dp); accuracy of the results of tax accounting, analysis and planning (Dr).

It is expedient to include in other non-measurable criteria: informative sources of information (Ii); confidentiality of information $(I C)$; the ratio of useful and background information $(I b)$.

The above list of indicators makes it possible to construct a system (vector) of criterion requirements to ensure the effectiveness of information about tax capacity of a business entity:

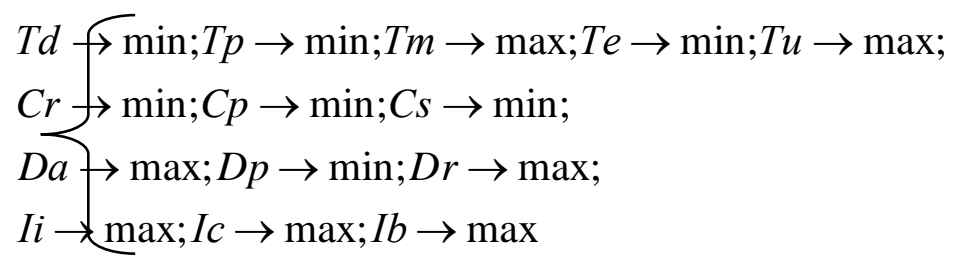

In order to work out the final solution, the obtained partial criteria by bringing them to an integrated evaluation of efficiency using the nonlinear compromise scheme can be analyzed [9; 12]. Thus, there is a number of ways to assess tax capacity, each with its own advantages.

Conclusions and further researches directions. The formation of information about tax capacity of an enterprise should occur not chaotically, but according to certain principles. Thus, the list of basic principles includes: unity, objectivity, competence, probability and periodicity. Additional principles (dynamism, rationality, conformity, control) should reinforce the action of the basic principles.

In assessing the effectiveness of the information system on tax capacity of the entity, one should take into account the impact of time and cost criteria, as well as other non-measurable parameters. The proposed approach to assessing the effectiveness 
of the current system of information on the taxpayer's capacity will allow assessing alternative information systems in terms of the effectiveness of their implementation.

The area of further further research is the development of weighing coefficients in order to adapt the criterion of effectiveness, depending on the dominance of certain factors over others in the current period of time.

\section{REFERENCES}

1. Rosenberg, G.S., Mozgovoi, D.P., \& Gelashvili, D.B. (2000). Ecology. Elements of theoretical constructions of modern ecology. Samara: Samara Scientific Centre of the Russian Academy of Sciences.

2. Zade, L.A. (1974). Fundamentals of a new approach to the analysis of complex systems and decision-making processes. Mathematics today [Collection of articles. Translated from English]. M.: Knowledge.

3. Nalimov, V.V. (1971). Theory of experiment. Moscow: Nauka.

4. Rosenberg, G.S. (1984). Models in phytocenology. Moscow: Nauka.

5. Fleishman, B.S. (1982). Fundamentals of Systemology. Moscow: Radio and Communications.

6. Forrester, D. (2003). World Dynamics: [trans. from eng.]. M.: "Publishing house AKT".

7. Zakhozhay, V.B., Lytvynenko, Ya.V., Zokhazhay K.V. et al. (2006). Tax system and tax policy / [ed. V.B. Zakhozhay \& Ya.V. Lytvynenko]. K.: Centre for Educational Literature.

8. Ivanov, Yu.B., Karpova, V.V., \& Karpov, L.N. (2006). Tax planning: principles, methods, tools. Kharkiv: Ingek.

9. Gudzinskyi, O.D., Sudomyr, S.M., \& Gurenko, T.O. (2010). Management of the formation of competitive potential of enterprises (theoretical and methodological aspect): monograph. K.: IPK DSZU.

10. Vyshnevskyi, V.P. \& Stetshenko, S.G. (2004). Estimation of influence of taxes on economic activity of industrial enterprises with the help of methods of economic and mathematical modelling. Donetsk: IEP NAN of Ukraine.

11. Voronkova A.E. (2000). Strategic management of the competitive potential of the enterprise: diagnostics and organization. Luhansk: Publishing House of East Ukrainian Un-ty.

12. Matviychuk A.V. (2007). Modelling of Economic Processes Using Fuzzy Logic Methods. K.: KNEU.

13. Pysarchuk O.O. (2010). Evaluation of the effectiveness of information systems by the vector of criteria. Collection of scientific works of ZhVI NAU, Issue 3, pp. 117-123.

14. Akoff R. (1985). Planning for the future corporation. Moscow: Progress.

15. Kustovskay O.V. (2005). Methodology of system approach and scientific research. Ternopil: Economic Thought.

16. Odum Yu. (1975). Fundamentals of Ecology. M.: Mir.

17. Shevchenko D.K. (2011). Principles of Strategic Stability Management of the Enterprise. Scientific notes of the Komsomolsk-on-Amur State Technical University, Vol. 2, No. 6, pp. 86-96.

18. Raevneva O.V. (2006). Management of enterprise development: methodology, mechanisms, models. Kharkiv: "Inzhech". 


\title{
CREATIVE THINKING, INNOVATION AND IDEA GENERATION IN MODERN MANAGEMENT
}

\author{
${ }^{1}$ Larisa Takalandze, ${ }^{2}$ Eliso Lanchava \\ ${ }^{1} \mathrm{PhD}$ in Economics, Professor. http://orcid.org/0000-0003-1126-6464 \\ ${ }^{2} \mathrm{PhD}$ in Economics, Assistant Professor. http://orcid.org/0000-0001-6790-5291 \\ 1,2Sokhumi State University (Tbilisi, Georgia) \\ Email: larok2706@gmail.com
}

\begin{abstract}
During the XXI century management has faced new significant problems. Today modern management aims to support innovative thinking and to remove the isolation of creative approaches. Creative management, which at the same time is a part of innovative management, helps people working in the organization to maximize their creative ability, accumulated knowledge to create new, competitive ideas that will be used to successfully operate the organization. Because organizations have to take into account the influence of various factors and creative flows, this in itself requires changes within organization and the ability to adapt to ever-changing conditions, which should be done not based on dogmas, but on new forms and methods. Modern management must ensure not only efficiency, but also creativity, innovative development. Creativity becomes part of success-oriented companies, which helps to avoid stagnation and see the issue from the new perspective. Creativity means exactly that - discover a unique opportunity in a problem, be able to perceive risk, break down patterns and create something valuable, different. This is exactly what the news brings.
\end{abstract}

Keywords: Creativity, Innovation, Creative thinking, Creative management, Innovative thinking,

Today, in the world of business and corporations, creativity is seen as the primary driver of specific benefits. Being a creative company, having a special product or service, and the same time maintaining a competitive edge is imperative in order to survive. So, organizations need innovation to survive, finding new solutions, new ideas. In modern reality, management depends on abilities, motivations, theoretical and practical knowledge \{1\}. Modern management includes all spheres of human activity and, one might say, all forms and types of activity. Accordingly, it is legal that the efficiency, competitiveness of activities, productivity and services, as well as the growth of new opportunities and processes, depend on the management object, process and content. In general, it is an ongoing process that controls all resources. The functionality of political, economic, social, ecological processes, dangers or other important issues depends on it $\{2\}$. Accordingly, the result of management, as a product of the main acting factor, is reflected in everything and everyone. In such an environment, radical and legitimate differences between many factors are at the root of the problem. The principles of traditional management models, which looked effective during a slow and predictable economic process, were ineffective in modern conditions. Success requires a hybrid combination of new and collected knowledge, which in the end must be manifested to ensure stable competitiveness. Decisions adopted in the management process as a product of intellectual labor become special and competitive only when they are transformed in one unity of the collected knowledge, or when such a detail is added to the knowledge, as a result of which it shows the best abilities. Accordingly, the role of the manager in achieving a specific goal is manifested as a decisive factor. The main source of all benefits, that is, the driving force is the person. While managing an organization, formulating and solving strategic and marketing tasks, the effectiveness of a potential result depends on such factors as the level of creativity of administrations and creative groups. Creativity is the main source of society's development. What does creativity imply? This is a person who thinks creatively, always especially because of individual thoughts, reflections and actions. It can somehow react quickly during problem situations and finds a non-standard, on the one hand, easy and most accurate way out, with which he surprises and excites people around him. Creativity is the most important factor in creating innovation. An innovative idea is a new (creative) idea implemented in practice, which, as a rule, comes out as a result of creative thinking $\{3\}$. Thinking is the hallmark of a person. Logical thinking works in only one direction. Conversely, creative thinking does not limit, but goes beyond. It uses thinking resources according to rules that do not obey logic. It is the idea, courage and unity by the impulse of thinking that unites in a person an artist, a creative person, a successful, intelligent, intelligent, innovator, that is, a person who creates epochs. Objects were not created for uniformity, and especially a person's goal cannot be onetime and unchanging. Thinking and its development represents the road to liberating mechanical impulses, obsessions, often incorrect beliefs and monotony. Creativity is a phenomenon through which the creation of something new and, in particular, special, is carried out. The created product can be both intangible (idea, piece of music) and a physical object (drawing, literary work, invention) $\{4\}$. Creativity is critical to running a business, especially in a technologically advanced field that is directly knowledge-based. Innovative thinking and intelligence provokes creativity in employees. Namely, the purpose of creative management is to identify creative opportunities in people when traditional administration is based on 
the activities of people with well-established rules and denies their initiative. Creative management implies such management of people in organizations, the goal of which is to maximize their capabilities, so that the basis for the manifestation of competitive ideas in various spheres of human activity is embedded. The goal is to generate new ideas, make non-standard decisions, both for the successful development of the company (organizations) and the country. It is imperative that the original ideas of the employees are heard. Make sure to hold meetings where employees personally provide ideas to leaders. The creativity of employees, one might say, depends not only on internal factors, but also on the organizational culture, on the working environment, on the forms of management. Accordingly, provoking creativity is possible by many methods, if the leader has the desire and willingness to consider different methods that will help the development of creative thinking in organizations $\{3\}$. Creative management must ensure that costs are minimized and that potential future benefits are maximized while building intellectual capital. Its main task is the creation of human capital activity and motivation, the activity of creative potential. We present several types of creative thinking and creative management:

- Brainstorming - This technique is based on an environment that the value of ideas can constrain our thinking when looking for new ideas. This often happens when a normal idea comes along and the thinking process stops automatically. Not after the manifestation of the idea, but the flow of the manifested ideas stops. Each team member subconsciously filters those ideas, after which he thinks that this idea is similar and not inappropriate and cannot express it. The main purpose of brainstorming is to separate the process of evaluating and communicating ideas. People present ideas without any judgment or thought. These ideas are written (on the board, on paper), and after that their assessment and debate begins around them. At the end, the most optimal idea is chosen.

- $\quad$ Checking by the method of assumptions - When we have to think about a question, several ideas are so grounded in our minds that they deny the opposite. When thinking creatively, you don't need to run away from the opposite assumptions. On the contrary, you always need to find alternatives, test assumptions. Once the question to be verified has been selected, a small group or individual members should start looking for the possibility of different opposing assumptions and highlight the dominant ideas. All assumptions are verified. This process takes place visually, preferably on a board. All possible results and benefits of assumptions and alternatives must be analyzed. The final result will be presented by the whole group (or one member) $\{5\}$. Within companies, creativity should not be imposed on one individual. Management must create an appropriate creative environment for the team and give incentive to each employee.

Great changes are taking place in the world today. Humanity still faces instability and uncertainty. The new revolution in sciences, technologies and industries has given the development of mankind new opportunities and also unprecedented challenges. In order to achieve general well-being, maintaining connections and communication, coordinated development is a legitimate choice. Transformation and innovation are the driving forces for the success and development of society. Anyone who denies changes and news is lagging behind the times and disconnected from activity. The innovativeness of the socio-economic development of the country must be considered as a form for the implementation of non-standard, creative ideas, both in economics and politics, in public life and art. Internal competition and the national innovation system are an important foundation for a competitive economy, economic security and, accordingly, the state's competitiveness on a global scale. Innovation plays an important role in a country's economic well-being. It is of particular importance for the development of the business sector. It promotes high competitiveness, which contributes to the development of business and economy $\{6\}$. Various studies show that where innovation is developed, the standard of living of society is high. And this is a clear indicator of a developed economy. Innovation represents a chance for developing countries to keep up with the developed world and improve living standards through a sustainable development path. Today, in world practice, there is a wealth of experience in the transition of economic development to an innovative regime, which is used in different economic and political conditions. Georgia, despite a number of problems, we can say that it retains scientific and technical potential, has important natural resources and another important resource - the high potential of entrepreneurs.

The main task lies in the fact that all its resources should be directed to the development of the country's economy $\{6\}$. In this regard, the development of the innovation sphere is of particular importance, since mainly in this area, on the basis of fundamental and using research, products are created that have high user characteristics.

The main condition for the development of the innovation sphere is the issue of training and education of working personnel in this area. Modern businessmen and managers operate in a completely different environment than 10-20 years ago. Based on this, it is imperative, taking into account the characteristics of the Georgian environment, to develop local employees and activate attention to development and establish a modern management culture. It should be taken into account that the effectiveness of management, its forms are directly related to the social, economic, and cultural traditions of the country. So, it is imperative, taking these factors into account, to organize the training of managers and the training system in accordance with the requirements of a modern market economy, attract the costs of domestic and international financial organizations, develop specific training programs and implement them. These programs need to be created taking into account international experience. In the area of increasing entrepreneurial skills, the non-governmental sector and international organizations can make a great contribution. It should be noted that there is some progress in this direction. Grant financing mechanisms have been created in Georgia, the Innovation and Technology Agency of Georgia 
has been created, which participates in the commercialization of the results of knowledge, innovation and research from the public and private sectors and in supporting innovative entrepreneurship. The first technology park was created, where large and small companies can work together. For representatives of the creative and engineering industries, such an ecosystem will provide an opportunity to initiate projects of higher value and interests in the global market. Over the past 11 years, the level of innovation in different countries has been measured by the Global Index (GII) and is annually prepared by Corneli University, the INSEAD business school and the World Intellectual Property Organization (WIPO). In 2018, in the research of the global innovation index, Georgia acquired the 9th position and with 35.05 points it takes 59th place. In the research, Georgia is among those 20 countries that, in contrast to the country's development, in terms of the development of innovations, shows high results. This is all good, although it should be noted that the country faces important challenges, which needs an integrated approach and solutions $\{6\}$. Small and medium-sized entrepreneurs invest less money in research and development, which hinders the creation of innovations and in the end, a less desirable result occurs. It is important that the results of this study are correctly understood and analyzed by the competent authorities in order to plan and implement those actions that will improve the situation and contribute to the development of the country, which, accordingly, will be reflected in economic growth. It is desirable that actions for the integration of Georgian scientists and the education system in a single European space be carried out in stages, also with the aim of developing cooperation in the field of research activities with neighboring countries of the region. With the creation of new technologies, industries, models, there is support for the development of globalizations in an open, inclusive, universal and profitable direction $\{7\}$. The government must ensure that the people living in the country have a sense of success, slavery and security. It is important for Georgia to study the theoretical achievements and practical experience of the civilized economic world and to establish and use them in economic management activities, which must be implemented in the near future.

\section{REFERENCE}

1. Kobalia E. "Creativity and its meaning" 2019 http:/ intermedia.ge

2. Maisuradze T. "Benefit Management"; Tbilisi 2014

3. Gorgodze S., Janashia T. "Creative and Artistic Thinking, Imaginary Education"; professional standards / portal of professional educational institutions, Tbilisi 2012

4. Bokuchava T. "Creativity, as predictor of successful life" $2019 \mathrm{http}: /$ intermedia.ge

5. http:/ucnauri.com

6. Sigua G. "The main tendencies of innovative economic development in the EU countries and in Georgia" GTU P. Gugushvili Collection of scientific works of the Institute of Economics; Tbilisi 2016

7. Maisuradze T. "Principles for solving management problems"; Economics N1-2 Tbilisi 2014 


\title{
MY PERSONAL LEADERSHIP EXPERIENCE
}

\author{
Lasha Takalandze \\ Master of European and International Studies (MEIS), University of Trento, Italy. http://orcid.org/0000-0002-6975-3604 \\ Email: larok2706@gmail.com
}

\section{Servant Leadership}

Leadership is perceived as an important asset for every organization. Furthermore, one of the key elements of leadership is the ability to influence others and to influence the decision-making process. One way of influencing decision-making processes uses what is called social influence. This describes the process where leaders are encouraging subordinates to change their behaviour and attitudes, with the intention of achieving certain goals. Traditionally it is perceived that this process happens from top to bottom through directives, but recently scholars have tended to identify it as multidirectional. So, just like leaders influence followers, followers can also influence leaders.

One of the multidirectional leadership processes is the concept of Servant Leadership. The servant-leader is servant first. It begins with the natural feeling that one wants to serve, to serve first. Then conscious choice brings one to aspire to lead. That person is sharply different from one who is leader first, perhaps because of the need to assuage an unusual power drive or to acquire material possessions. For such it will be a later choice to serve - after leadership is established. The natural servant, the person who is servant first, is more likely to persevere and refine a particular hypothesis on what serves another's highest priority needs than is the person who is leader first and who later serves out of promptings of conscience or in conformity with normative expectations.

There are other interpretations regarding the servant leadership. According to Peterson's model the Servant-leaders are those who serve with a focus on the followers, whereby the followers are the primary concern and the organizational concerns are peripheral. Peterson's theory includes the following constructs, in that the servant leader:

- $\quad$ Leads and serves with love;

- $\quad$ Acts with humility;

- Is altruistic;

- Is visionary for the followers;

- Is trusting;

- Is serving;

- Empowers followers.

Thus, in $21^{\text {st }}$ century we see that the traditional styles of leadership are slowly yielding to a better model - one which is based on teamwork and community; one which seeks to involve others in decision making; one which is strongly based in ethical and caring behaviour; and one which is enhancing the growth of people, while at the same time improving the caring and quality of many institutions. It is called emerging approach to leadership and service, servant-leadership. In all of these works, Greenleaf describes the need for a new kind of leadership model - a model which puts serving others as the number one priority. Servant-leadership emphasizes increased service to others; a holistic approach to work; promoting a sense of community, and the sharing of power in decision making.

Since 1970, servant-leadership crosses all boundaries and is being applied by a wide variety of people working with forprofit businesses; not-for-profit corporations; hospitals, government, churches, universities and foundations. Individuals within institutions have adopted servant-leadership as a guiding philosophy. An increasing number of organizations have adopted servant-leadership as part of their corporate philosophy, or as a foundation for their mission statement. However, the Servant leadership is dominant leadership style in Non-Governmental Organizations and Civil Society Organizations. Thus, in my paper I am going to focus on the Servant Leadership in the Non-Governmental Organizations.

A non governmental organization (NGO) is a not-forprofit, voluntary citizens' group, which is organized on a local, national or international level to address issues in support of the public good. While play more important roles in social services, the NGOs are becoming more practical, flexible, and less strict. The organizations provide analysis and expertise, serve as early warning mechanisms and help monitor and implement international agreements.

Increasingly, the existence of NGOs is proving to be a necessity rather than a luxury in societies throughout the modern world. Prompted by the inadequacies of the state and the market, citizens across the globe have developed organizations of civil society - NGOs - to help address a wide variety of social needs. NGOs have three primary roles in advancing modern societies.

First, NGOs provide opportunity for the self-organization of society. NGOs enable citizens to work together voluntarily to promote social values and civic goals which are important to them. They promote local initiative and problem-solving. Through their work in a broad array of fields - environment, health, poverty alleviation, culture \& the arts, education, etc. NGOs reflect the diversity of society itself.

Second, NGOs preserve a unique and essential space between the for-profit sector and government. Clearly private enterprise is efficient at producing goods and private wealth. Government is best when it focuses on providing and managing public goods. The nonprofit, non-governmental sector helps fulfill the common good. 
Finally, NGOs enable experimentation and social change by taking on challenges that the public and private sectors simply can't or won't. Civil society organizations are able to take risks that are economically unacceptable to business and politically unacceptable to government.

Thus, NGOs are discussed as the subject of civil society. Civil society has many definitions and has been termed by some scholars basically as the collection of all NGOs working together with governments and private businesses. Civil society can be defined as a combination of social capital, civil society activism and civic associationalism - the public sphere where the civic engagement, ideas and ideologies can be debated. As the number of NGOs increasing worldwide as their voices within the civil society becoming stronger, because NGOs present a variety of global issues. NGOs are mainly working by human rights, environment, healthcare groups or by geographical locations, like: Middle East, Latin America, Post-Soviet countries etc. I would like to point out the important role of NGOs in post-soviet countries after the collapse of Soviet Union. E.g. the spheres of activity of NGOs in Georgia are rather diverse. The most wide-spread among them are the following: human rights, support of democracy and civil society, environmental protection, women's issues, child and adolescent issues, youth problems, health care, state reform support, conflict resolution and peace-building, support for local self-government and refugee problems.

\section{Young Leaders' Club - My Leadership Experience}

While my bachelor's in 2012 I decided to found a Non-Governmental Organization 'Young Leaders' Club' (YLC) in Tbilisi, Georgia. This organization was focused mainly on youth activities. Georgia as a post-Soviet country is facing a lot of socio-economic and political problems. For me, as a student the most important challenge was the ineffective education system and lack of opportunities for youth in Georgia. Many Georgian young people are not able to enhance the modern and high level education, because at the most local universities education system is still based on the old 'soviet-style' teaching method and I was not satisfied with the fact that I was not competitive with western European and American students. 2012 I studied for one year at the Maastricht University as an exchange student, program of International Business and when I compared Georgian education system with the Dutch one, I realised that Dutch education system was much more advanced. I decided to take action and to create an education platform for young people, to give them access to modern theories in Leadership and Communication. Mission of the Organization was to 'Contribute to the development of civic society of Georgia. Support young people to develop their effective leadership skills'. Vision of the Organization was 'To become international Non-Governmental Organization'. And we have created values of the organization: 'Continues education; Striving towards excellence; Coherence of plans and actions (activities); Respect for each other; Building long-term and trusted relationships'.

The role model for YLC was the organization 'Teach for America' TFA; it was founded on a belief in the potential of all children and their right to an excellent education, and they continue with the same bold vision today. In 1989, Wendy Kopp had a big idea, to address a national teacher shortage and dire academic issues for low-income kids that had not improved in a century. Her plan-to recruit high-performing college graduates to teach in high-need urban and rural schools-was truly innovative. In December 1989, Wendy gathered 100 part-time student recruiters from 100 universities to begin TFA's first recruiting season. Arguably such transformational leaders enabled ordinary people to achieve extraordinary results. Teach for America is a collective force of educators and leaders who are expanding opportunity for all children; The main moto of this organization is that opportunity, progress, freedom - begins with education, therefore every teacher can help students to succeed academically during two years. Volunteers are gaining outcomes, as they are mostly students, they are developing as learners, leaders, advocates for themsleves in pursuit of their goals. Right now, TFA is serving more than 50 regions and with nearly 62,000 people in their alumni and corps member network, their focus has evolved from an emphasis on the individual to an emphasis on the network and collective leadership.

Our organization YLC united around 50 active young people under one common goal, to support other youth to develop their leadership and communication skills. We adopted the team-based leadership approach, which means that leadership is collective task based on shared decision-making and delegated authority. Leadership was perceived as an social process in which everyone was engaged and was seen as an investment in building the social capital of an organization. Thus, I was sure that our organization would contribute to the development of civic society in Georgia, to encourage the young people and involve them in active socio-economic and political life. I realized that the influence of culture and context is very important for the effectie functioning of the civil society organizations. Not only the leaders of the organization play a central role in shaping the destiny of many NGOs, but also the environment in which they operate.

\section{Cultural Context of Georgia}

Let have a look on the cultural context of Georgian society. I would like to describe Georgian cultural context based on the Dutch scholar Geert Hofstede's research. According to Hofstede's cultural dimensions, Georgia demonstrates a slight tendency to the higher side of Power Distance and thus, it is a hierarchical society. This means that members of the society to a large extent accept a hierarchical order in which everybody has a place, and Georgian society tends to be a collectivist culture. Society fosters strong relationships where everyone takes responsibility for and protects fellow members of their group. Loyalty is paramount and overrides most other societal rules. Georgian culture is more normative than pragmatic. People in such societies have a strong concern with establishing an absolute truth; they are normative in 
their thinking. And Georgia has high scores in uncertainty avoidance as well, the tendency to avoid any uncertain circumstances.

The critical point in my leadership experience ewas to respond to the cultural context of Georgia. We as NGO activists were students and did not have much leadership experience, we failed to adopt relevant leadership style to the Georgian society. Georgia is a high-context culture with hierarchical society, therefore participative or supportive leaderhsip style was irrelevant for such an environment. The most important aspects for this are from pressure of work, and the demands of organizational crises - financial shortfalls, internal conflicts or tensions between the staff and the board. The donor's emphasis on tight project schedules, over hasty timeframes and quick results were both unrealistic, developmental badpractice, and had a negative impact on the credibility and confidence of NGO leaders. Such demands had a detrimental effect on the ability of NGO leaders to pursue long-term goals or develop a degree of financial sustainability.

\section{Leaders' attributes}

Another important aspect was the leader's attributes. Leaders' attributes are the traits interact with ability to engage in servant leadership (very important attributes for leader is moral development, emotional intelligence, agreeableness, humility). My task was not to put greatness into people, but to elicit it, for the greatness is there already. As many researchers suggest, the emotional niteligence is a crucial point for leader. Emotional intelligence is described as the ability to motivate both yourself and others, many effective leaders demonstrate high level of self-awareness are capable of self-management. Main strategy was to inspire team members, motivate individuals, identify opportunities and initiate transformation. We were organizing trainings, seminars on Leadership and Communication, as well as we were implementing projects, e.g. Model United Nations Conference at the Ilia State University in Tbilisi, around 70 students participated in this project. We were supporting young individuals to show off their talent in different fields. I tried to give platform to young performers and professionals. E.g. I organized the presentation of short movie 'Three Gold', shoot by young director, and all of the actors and actresses were by origin refugees, from Abkhazian region. We dedicated them our office to present movie and gave them chance to meet with prospective producers. Another example was the numerous student led events organized by YLC. E.g. events of poetry to encourage young poets and novelists. Implementing projects to support young musicians and performers. I was presenting the international projects in secondary schools, offering secondary school students participation in UN conference in New York UN office, to discuss youth activities and issues at the UN level.

\section{NGO Leadership and Change}

It should be noted that the strong leadership is most needed in time of change. Georgia is a post-Soviet, transition economy country, with rapidly changing environment. I tried to affect change in such a static and traditional society. Together with my friends I was aspiring to create an alternative non-formal educaitonal environment, which would be, unlike the traditional educational institutions, decentrilised and egalitarian platform, where young people could get inspiration to act independently and innovatively, to provide positive change for the community. Very important for the leader is to change himself as well, not only the organization, as Nelson Mandela stated: 'You can never change society if you have not changed yourself.' I was moderating the TV show regarding the youth problems and activities at the Student television 'STV'; I invited the international and local professional, public field representatives and we were discussing the socio-economic and international political issues, as well as we were organizing meetings between students and Georgian politicians to discuss perspectives for youth, organizing public lectures and other activities to promote change in our community.

We were actively cooperating with the media and have been presenting the projects, trainings, events organized by the Young Leaders' Club in the Georgian National Televisions. 2014 we held an environmental project 'planting action' together with Tbilisi City Hall in Tbilisi Digomi Park. YLC members participated in cleaning the city damaged by the flood in Tbilisi, June 2015, and we, together with thousands of other volunteers, helped Tbilisi to recover. These are the positive contribution to our community. As the vision of organization was to become international organization, we started to sign contracts on the cooperation with foreign organizations. On May 21-24 2015 in Poland was held an international scientific conference "Education and the Economy" organized by - the "European Scientific Foundation Institute of Innovation" and the Włocławek City Hall. The NGO "Leaders' Club" signed an agreement on cooperation with the "European Scientific Foundation Institute of Innovation”.

\section{Critics}

Despite some successes achieved by our team, we could not achieve our goal to become international organization, and the main reason was the lack of competence in leadership and we were not able to build close ties with the prospective donor organizations.

The primary purpose of any NGO-based Leadership Development Programs is to develop new generation of NGO leaders. Despite the fact that we incorporated several activities in the Leadership development (coaching and mentoring; self-assessment questionaries; journaling and narrative description; photographs and video diarying; cases and simulation exercises; specialist workshops and seminars; learning sets and peer group support), the development of new generation of NGO leaders was one of the largest challenges for our organization. I have focused on the organizational activities 
rather than to promote changes to the attitude and behavior of individual leaders. The main reason for this issue was our lack of leadership competences. Rewarding incompetence and lack of accountability, as well as the 'Cliquishness' become the main problem in the NGO leaders' development way. Only $15-20 \%$ of organization member were actively involved in the volunteering activities, so this $15-20 \%$ become the very close 'friends' and the decision-making process became centralized, without consulting with other members, this has driven to the 'Cliquishness'. Another critics is related to the hubristic leadership, which is defined as an exaggerated pride or confidence often resulting in retribution. The symptoms of Hubris Syndrome are expressed in behaviours such as inflated self-confidence and self-perception, arrogance, messianic manner, lack of humility and contempt.

\section{Conclusion}

In conclusion, despite the challenges, successes and failures in my leadership experience, I would agree, that being servant leader means to be able to learn by doing, to develop strong communication and interpersonal skills, and to have ability create networking and partnership. Servant leaders act as strategic catalysts within the NGO context, and have the ability to promote and implement change in society. They demonstrate a wider world-view, and the capacity to take a longer-term strategic view while balancing tough decisions about strategic priorities with organisational values and identity.

\section{REFERENCES}

1. Robert K. Greenleaf, 'The Servant as Leader', Paulist Press, 1977;

2. Robert S. Dennis, Linda Kinzler-Norheim, Mihai Bocarnea, ,Servant Leadership Theory: Development of the Servant Leadership Assesment Instrument', pp.169-179, Palgrave Macmillan, 2010 London;

3. Larry Spears, Reflections on Robert K. Greenleafand servant leadership', Leadership \& Organization Development Journal 17/7 (1996), pp.33-35, Indianapolis, USA;

4. Kuldip Singh, 'Servant Leadership in Non-Governmental Organizations (NGOs)', Journal of Administrative Science, Universiti Teknologi MARA (UiTM), Malaysia 2014;

5. Ghia Nodia, 'Civil Society Development in Georgia: Achievements and Challenges', Caucasus Institute for Peace, Democracy and Development, Tbilisi 2005;

6. See the full text: https://www.teachforamerica.org/what-we-do/history

7. See more information: https://www.hofstede-insights.com/country-comparison/georgia/

8. Dragos-Catalin Apostu, 'Non-Governmental Organization Leadership and Development', Change and leadership, 2013;

9. Eugene Sadler-Smith, Vita Akstinaite, Graham Robinson, Tim Wray, 'Hubristic Leadership: a review', SAGE, PP Vol. 13(5) 525-548, 2017;

10. John Hailey, 'NGO Leadership development - literature review', INTRAC, July 2006; 


\title{
MODERNIZATION OF THE PUBLIC ADMINISTRATION SYSTEM IN THE CONDITIONS OF DECENTRALIZATION OF POWER
}

\author{
${ }^{1}$ Olha Rudenko, ${ }^{2}$ Tetiana Shestakovska \\ ${ }^{1}$ Doctor of Science in Public Administration, Professor. https://orcid.org/0000-0002-2807-1957 \\ ${ }^{2}$ Doctor of Science in Public Administration, Associate Professor. http://orcid.org/0000-0002-8098-8439 \\ ${ }^{1,2}$ Chernihiv Polytechnic National University, Department of Public Administration and Management \\ E-mail: rudenkolgam@gmail.com, shestakovska27@gmail.com
}

\begin{abstract}
Strategic course of Ukraine towards European integration requires a new conceptual basis for the institutionalization of power, the introduction of a modern model of public administration. In the conditions of democratic transit, Ukraine and the countries of Central and Eastern Europe should use a conservative Neo-Weberian State (NWS) Model. This model is normative in terms of implementation in Ukraine, because our country, first, has accumulated necessary democratic potential of public initiative; secondly, it has a tradition of strong state power, capable of independently performing the functions of public goal-setting and making appropriate organic decisions; third, it is able to ensure the longevity of public policy at all administrative levels; fourth, preserves stable corporate values and rules of the civil service; fifth, seeks to bring the process of modernization of the domestic public administration system closer to European standards and practices. The normative and legal conditions necessary for the modernization of the current system of public administration in Ukraine in the direction of implementation of the principles of public administration have been generalized. In Ukraine, modernization of the public administration system, aimed at forming a new model of public administration, is possible only if the objective and subjective preconditions are taken into account, which are critical for the successful implementation of decentralization. It has been identified the following promising stages of decentralization in Ukraine: 1) deconcentration of powers and resources, their legally justified transfer from central government to regional and local government bodies; 2) compliance with the principles of devolution of power; 3) powers and resources will be distributed between traditional public authorities (state and self-governing) and market and public structures; 4) introduction of the newest models of public management, built on the principles of the New Public Management paradigm. Keywords: public administration, state government, decentralization, modernization, European integration.
\end{abstract}

\section{INTRODUCTION}

In Ukraine, as in the vast majority of countries in the modern world, there are radical changes in all spheres of public life, in particular, due to the processes of global socio-economic and civilizational transformations. These changes significantly affect the activities of all governmental and non-governmental political institutions, which ensure the direction of social development and determine the ability to meet internal and external challenges. Such global challenges highlight the need for systemic reforms aimed at modernizing Ukrainian society and the state, ensuring balanced progress of the country as a highly developed, legal, and civilized European state with a high standard of living, social stability, a stable democratic tradition. Public administration as an integrated model of social management common in democratic countries is a necessary organizational, legal, and institutional environment for the introduction of decentralization of power. The traditional model of public administration assumes the possibility of vertical deconcentration of power, which in the modern world is considered only the first step towards decentralization. The transitional model of public administration, which is currently being formed in Ukraine, recognizes the need for devolution of power in the direction of transferring powers and resources of public administration bodies to local self-government bodies, which will create a qualitatively different level of government in the state.

Analysis of recent researches and published papers. The papers of both foreign and domestic scientists are devoted to the decentralization of power. Particularly, the theory and practice of the process of decentralization of public administration were studied by O. Bosak, V. Hroisman, B. Danylyshyn, M. Izha, H. Kovalenko, V. Kozak, V. Kuibida, V. Mamonova, N. Nyzhnyk, O. Olshanskyi, M. Pukhtynskyi, and others. The scientific works of V. Bakumenko, T. Bielska, V. Hrynevych, V. Dziundziuk, D. Karamyshev, K. Kolesnykova, V. Korzhenko, V. Martynenko, O. Orlov, M. Pasichnyk, V. Solovykh and others are devoted to the modernization of the public administration system. Despite a large number of domestic professional publications, there is a lack of research on the phenomenon of modernization of the public administration system in terms of the causal link with the decentralization of power.

Results of the research. Consistent decentralization as a qualitative transformation of the current system of public administration in Ukraine is possible only in case of a purposeful transition to one of the common models of public administration in developed democratic countries. Summarizing the proposals of Ukrainian and foreign authors on the implementation of public administration, we highlight the following: 
- gradual transformation of public administration bodies and local self-government bodies on the basis of introduction of a single qualitatively homogeneous system of public administration from top to bottom;

- separating political powers (goal-setting) of public administration bodies from purely executive functions (achievement of the goals set);

- ensuring the efficiency and accountability of local public administration bodies; transition from a system of responsibilities based on the implementation of internal system rules to reporting based on socially significant results of activities;

- constitutional guarantee of the independence of local self-government bodies in the performance of the administrative functions assigned to them within the framework of general political control in the forms established by law;

- reforming the public service system in the direction of its further depoliticization, rationalization, and personification, ownership to civil society bodies authorized by law;

- disseminating a new ethos (moral rules and obligations) of public service in accordance with the new social role of public administration bodies, ie abandonment of their de facto monopoly in the process of making and implementing public administration decisions to a purely executive status along with public and business organizations, as well legally endowed with public functions.

The first step towards the introduction of modern principles of public administration should be the formation of political, economic and institutional conditions for modernization, necessarily related to the subjective readiness of the population for painful change; and only then, as the next logical step, the transition from the traditional domestic system of public administration to the classical model of public administration by the European standard, which acts as an ideal type (proper organizational and legal form) of the transformation process. The characteristic features of the latter include the final separation of public and private interests in the management environment and, accordingly, the political and executive functions of public administration bodies. The central assumption of the classical model of public administration, researchers consider the hierarchical construction of policy-making bodies and the direct subordination of public servants to the governing bodies [1].

In the conditions of democratic transit, Ukraine and the countries of Central and Eastern Europe should use a conservative Neo-Weberian State (NWS) Model than the prescriptions of the New Public Management and the good governance built on its principles. The concept of the NWS Model was suggested in 2004 by Christopher Pollitt and Geert Bookert to describe the European practice of modernizing public administration, in contrast to the Anglo-Saxon model of "marketing" the state.

From a conceptual point of view, the NWS Model can become normative in the domestic context, however, with significant remarks on the peculiarities of its genesis, modern development, and short-term prospects. Among the regulatory and legal conditions that ensure the modernization of the current system of public administration in Ukraine in the direction of implementing the principles of public administration, we highlight the most important [2-3]:

1. Revision of the constitutional principles for exercising power at the local level, establishing a qualitatively unified administrative-territorial system of organization of power, based on the principles of the European Charter of Local Self-Government.

2. It is necessary to abandon the division of local government into state (local public administration bodies) and selfgovernment (local self-government bodies), which was clear at the time of the formation of independent Ukraine, but is ineffective today. At the regional and local level, it is necessary to create a single system of local selfgovernment bodies, which are elected by the population of the particular administrative-territorial unit and by law or special agreement receive from the central government necessary resources and powers.

3. Central public administration bodies (first of all, executive bodies) should be legally deprived of the right to individually establish the list of such powers, their scope, and the amount of necessary resources. Such decisions must be made based on a separate law in prior consultation with a specific local government body.

4. The law should provide the introduction of the principle of priority of legal requirements of local self-government bodies regarding the list and scope of delegated powers and resources.

5. Central public administration bodies become the highest level of bodies in the public administration system, and not a separate directive power institution, which maintains a de facto monopoly on the development, adoption, and implementation of government decisions with further quality control and timeliness of their implementation.

6. Only under such conditions it is possible to create an effective system of interaction of central public administration bodies (higher bodies in the public administration system) with regional and local public administration bodies.

7. The introduction of the institute of state supervisors (prefects), that by law control the activities of local selfgovernment bodies, is logical and justified within the transition period, and not as a permanent supervisory authority. Other external administrative restrictions on the activities of local self-government bodies should have the same transitional status, as the existence of such restrictions contradicts the requirements of the European Charter of Local Self-Government and other international instruments ratified by Ukraine.

8. The Constitution should include the principle of impossibility of early dissolution of a certain local self-government body (both elected and appointed), except by a decision of the Constitutional Court of the country, which has 
entered into force. The decision on early re-election (re-appointment) of a local executive body may be made only by the relevant elected body representing the interests of the community. Re-election of an elected body is carried out by a decision of a local referendum or a qualified majority of local deputies.

9. Internal financial control (internal audit) in the system of public administration is gradually transformed into an external public audit of activities carried out by both independent certified professional organizations of the third sector (auditors' associations) and directly by representatives of organized society, whose powers are established by law and individual agreements on a tripartite partnership.

10. It is on such public principles that the external general and financial audit of the activities of regional and local self-government bodies should be based. The principle of independence of local self-government bodies in resolving internal issues, recognized in the European Charter of Local Self-Government, should become fundamental in the development of relevant national legislation.

11. Internal control over the activities of local executive bodies should be exercised by local councils freely elected by the population of the community, and the priority right of external control should belong to public organizations operating in the community. External control by higher-level public bodies is possible on the basis of the law in the case of verification of the correctness of the use of funds of the relevant subventions or at the request of the authorized part of local deputies. For this purpose, in the regions, regional audit chambers are created on the principles of independence in the exercise of statutory powers. Such regional audit chambers receive the exclusive right to inspect the activities of local government bodies (both elected and appointed).

12. In the case of a conflict of interest or otherwise, the final resolution of the dispute shall be left to the discretion of the supreme national public audit body (the Accounting Chamber), which shall act on a non-interfering basis.

13. Territorial representations of central executive bodies shall exercise their powers in the manner prescribed by law, which provides for the obligatory coordination of their decisions with local self-government bodies. Exceptions can be made only for central executive bodies with a special status, the exclusive list of which is determined by law.

14. Local self-government bodies are gradually gaining priority rights in the implementation of budget decentralization, ie the administration of tax revenues from the bottom up, and not vice versa, as today. The principles of building a tax system on a consistent basis of budget decentralization (harmonization of revenue and expenditure parts of the local budget) should be fixed in a separate law. The central government bodies are deprived of the right and ability to arbitrarily interfere in local financial affairs.

15. All land plots within territorial communities without exceptions (but considering national interests) should be administered by special representations of the elected body of local self-government. Only under such conditions do local public bodies acquire the financial and organizational stability necessary to exercise their statutory powers.

These legal conditions can provide only the first step towards creating a system of public administration by the European standard. They also must include the requirements of a subjective nature, namely:

- readiness of civil servants and employees of local self-government bodies to work in new conditions, namely to the gradual loss of powers of a directive nature and the transition to the implementation of responsibilities for coordinating the activities of public administration bodies at various levels;

- their ability to cooperate with representatives of the private sector and public organizations, which by law or agreement acquire rights to perform part of public functions;

- stable public trust to ongoing reforms, as well as to the political power leading the reform process;

- a high degree of public participation in the activities of public administration bodies at all levels, which provides a legally approved opportunity for the business environment and civil society to influence the development, implementation, and ultimate control over political and executive decisions;

- $\quad$ such power influence should be two-sided: first, in the sphere of making power decisions, and, secondly, in the matter of their execution, in which private and public organizations are directly involved [4-5].

The result of the proposed changes will be the formation of the foundation for future changes. The central public administrative bodies, as we have seen, are losing their monopoly on social initiative, however, sufficiently retain their organizational structure and tangible power influence. At the first stage of modernization, they transfer powers and resources to a lower level of their own administrative system, ie carry out the deconcentration of power within the current system of public administration. In the second stage of transformation, local self-government bodies come to the fore, becoming the main recipients of power. Such a devolution of power opens the way to a practical transition to laying the foundations of the public administration system, as the monopoly status of central executive bodies is significantly weakened, and the importance of local self-government bodies in the conditions of actual liquidation of local selfgovernment bodies increases significantly.

Successful completion of the second stage (its chronological framework is difficult to determine precisely) logically leads to the creation of a single system of public administration bodies that have the same power nature and differ only in the administrative level and extent of statutory powers. Of course, this is not about the powers of central government bodies in relation to military, foreign policy, and other special functions, which by their nature cannot be transferred to other levels of government. The next, third stage of modernization of public administration is associated with improving the newly created 
system of public administration in the direction of its deep democratization, ensuring public participation in government institutions, public control over the results of their work, ie quality and timeliness of public services and goods [ 6]. In Ukraine, modernization of the public administration system, aimed at forming a new model of public administration, is possible only if the objective and subjective preconditions are taken into account, which are both critical for the successful implementation of decentralization.

1. Formation of a favorable socio-political situation, reaching a public consensus on the purpose, directions, and timing of modernization.

2. Development of a system of local public administration bodies on the ground, which should radically overcome the current dualism of regional public administration bodies and local self-government bodies.

3. Preventing the manifestations of decentralization in a socio-economic and political crisis.

4. Objective ability and subjective readiness of the ruling elite (first of all, state administrative) to cede a significant share of powers in favor of local self-government bodies, market, and public structures.

5. Formation of an extensive system of public organizations capable of effectively performing public functions.

6. Existence of developed market structures, ready to take on important public functions, first of all, in the communal sphere, the spheres of social protection, health care, ecology, etc.

7. Creation of an effective mechanism for the implementation of a tripartite (state - market structures - public organizations) partnership.

8. Ability of local self-government bodies to effectively use new powers and appropriate resource base.

9. Professional training of local government officials, market, and public organizations capable of performing extended duties in the new status (Table 1) [6-7].

Table 1

Impact of decentralization of power on the implementation of the principles of public administration

\begin{tabular}{|c|c|c|}
\hline № & $\begin{array}{l}\text { Direction of } \\
\text { implementation of } \\
\text { public } \\
\text { administration }\end{array}$ & Role of decentralization \\
\hline 1. & $\begin{array}{l}\text { Coordinating public } \\
\text { administration and } \\
\text { local self- } \\
\text { government bodies }\end{array}$ & $\begin{array}{l}\text { Decentralization in the form of deconcentration actually preserves the dualistic system of } \\
\text { local government, as it only redistributes power within the state without changing its } \\
\text { qualitative nature. } \\
\text { Devolution leads to the gradual abandonment of local public administration bodies, and } \\
\text { their main functions are transferred to local self-government bodies. On this basis, it is } \\
\text { possible to form a unified system of public bodies and establish effective coordination of } \\
\text { their activities }\end{array}$ \\
\hline 2. & $\begin{array}{l}\text { Separating political } \\
\text { powers }\end{array}$ & $\begin{array}{l}\text { Within the current system of public administration, even with the deconcentration of } \\
\text { power, this goal is unattainable. Moreover, there is a potential for decentralization as a } \\
\text { forced response by the central government to the aggravation of the socio-economic and } \\
\text { political situation in the country. } \\
\text { In the future, divestment (or functional horizontal decentralization) will provide the } \\
\text { translation of certain public functions to non-governmental (market and public) structures, } \\
\text { which will solve this problem in principle }\end{array}$ \\
\hline 3. & $\begin{array}{l}\text { Ensuring the } \\
\text { efficiency and } \\
\text { accountability of } \\
\text { local public bodies }\end{array}$ & $\begin{array}{l}\text { One of the main advantages of decentralization is to ensure broad participation of } \\
\text { citizens in addressing local issues (the higher the degree of decentralization, the higher } \\
\text { their scope and social weight,). Public control on the ground is a more effective means of } \\
\text { ensuring real accountability of the authorities than traditional specialized control and } \\
\text { supervisory bodies }\end{array}$ \\
\hline 4 & $\begin{array}{l}\text { Constitutional } \\
\text { guarantee of the } \\
\text { independence of } \\
\text { local self- } \\
\text { government bodies }\end{array}$ & $\begin{array}{l}\text { Implementation of consistent decentralization on the principles of the European Charter } \\
\text { of Local Self-Government will ensure independence and autonomy of unified public } \\
\text { administration bodies at different administrative levels. } \\
\text { By law, the functions of general control will be transferred to independent decentralized } \\
\text { professional control bodies, built on the principles of tripartite (state bodies, market, and } \\
\text { public organizations) partnership }\end{array}$ \\
\hline 5 & $\begin{array}{l}\text { Reforming the } \\
\text { public service } \\
\text { system in the } \\
\text { direction of its } \\
\text { further }\end{array}$ & $\begin{array}{l}\text { In the conditions of modern civil service as a centralized corporation that maintains de } \\
\text { facto monopoly on the exercise of state power, its depoliticization is not possible. } \\
\text { The transfer of power in the first stage of decentralization to local self-government bodies } \\
\text { (devolution) and to non-governmental (market and public) structures in the second stage } \\
\text { (divestment) will make the public service truly transparent and open to society }\end{array}$ \\
\hline
\end{tabular}




\begin{tabular}{|c|c|c|}
\hline & $\begin{array}{l}\text { depoliticization, } \\
\text { rationalization, and } \\
\text { personification }\end{array}$ & \\
\hline 6 & $\begin{array}{l}\text { Disseminating a } \\
\text { new ethos (moral } \\
\text { rules and } \\
\text { obligations) of } \\
\text { public service }\end{array}$ & $\begin{array}{l}\text { The subjective sphere of the process of establishing the principles of public } \\
\text { administration contains independent problems regarding self-determination of current } \\
\text { civil officials, self-assessment of their role, and place in the transformation process. } \\
\text { It is consistent decentralization, which creates a new social and managerial context for } \\
\text { the activities of public administrative bodies, that can most effectively influence the } \\
\text { solution to these problems }\end{array}$ \\
\hline
\end{tabular}

As a result, successful implementation of decentralization (transition to divestment and divestition as a higher quality level of its implementation) will allow, among other things:

- $\quad$ increasing the accountability and responsibility of government structures by forming their new structure, closer to people and open to their initiatives;

- $\quad$ reducing abuse of power through transfer of certain functions of the central government to lower levels;

- $\quad$ improving political stability by giving organized territorial groups the opportunity to control the process of resolving local problems;

- increasing political competition by creating new small communication platforms for regional politicians to compete.

Within the traditional model of public administration, it is possible to introduce these prerequisites successfully and implement decentralization in the form of devolution and divestment (functional horizontal decentralization). However, gradual progress through modernization reforms will lead to the acquisition of qualitatively new organizational and functional capacities by the domestic system of public administration, which will eventually allow moving to another, a higher level of public administration.

\section{Conclusions}

Analyzing the practical directions of implementing the principles of public administration, formulated in the previous section, we will try to summarize our conclusions that decentralization is the core element of each of them. At the first stage, within the traditional model of public administration, devolution of powers and resources is carried out, their legally justified transfer from central government to regional and local self-government bodies, ie within a single vertical of the executive branch of government. Deconcentration is able to bring power institutions closer to the population and its real problems, but it is by definition not able to weaken their policy influence on solving socially important problems. Therefore, deconcentration is only the first preparatory stage. This is the current stage of state development of Ukraine.

At the second stage, powers and resources are transferred from central and local public administration bodies to local self-government bodies on the basis of the devolution of power. As powers and resources are transferred to local selfgovernment bodies, which are qualitatively different from public administration bodies, such actions lead to significant reform of the system of power relations as a whole, although they preserve the basic principles of the traditional model of public administration. We can move to this stage only after the approval of the necessary amendments to the Constitution of Ukraine.

Only at the third perspective stage are powers and resources distributed between traditional public administration bodies (state and self-governing) and market and public structures in order to ensure greater social efficiency and effectiveness of their use. It is at this stage that the qualitative transformation of the traditional model of public administration into the modern model of public power is carried out on the basis of functional decentralization or divestment. The modern model of public power is in its transitional form, in which the state retains a relatively large power of influence, and market and public institutions only gain public weight and social influence.

At the fourth stage, Ukraine gets the opportunities to introduce new models of public administration based on the paradigm of New Public Management, ie the era of decentralized or a stateless state). Although, it is chronologically quite remote from Ukrainian realities, however, it can be possible due to the formation of a viable business environment and developed civil society.

\section{REFERENCES}

1. Katsamunska P. Classical and Modern Approaches to Public Administration. Economic Alternatives. 2012. №1. P. 74-8.

2. Danylyshyn B.M., Pylypiv V.V Detsentralizatsiia u krainakh YeS: uroky dlia Ukrainy [Decentralization in EU countries: lessons for Ukraine]. Rehionalna ekonomika - Regional economy. 2016. № 1. P. 5-11 [in Ukrainian].

3. Bakumenko V.D., Popov S.A. Paradyhma innovatsiinoho rozvytku suspilstva: suchasni kontseptsii reformuvannia publichnoho upravlinnia [Paradigm of innovative development of society: modern concepts of public administration reform]. Efektyvnist derzhavnoho upravlinnia - Efficiency of public administration. 2015. Vol. 43. P. 21-28 [in Ukrainian]. 
4. Pukhtynskyi M. Zasady detsentralizatsii publichnoi vlady [Principles of decentralization of public power.]. Viche Chamber. 2015. №12. P. 29-31 [in Ukrainian].

5. Melnychuk A., Ostapenko P. Detsentralizatsiia vlady: reforma № 1 [analitychni zapysky] [Decentralization of power: reform № 1 [analytical notes]]. K. : TsOP «Hlobus» FOP Kravchenko Ya.O. 2016. 35 p. [in Ukrainian].

6. Boggero Giovanni (Università degli Studi di Torino). Constitutional Principles of Local Self-Government in Europe. Leiden, Netherlands; Boston : Brill, 2017. 334 p.

7. Faguet Jean-Paul. Decentralization and Governance. World Development. 2014. Vol. 53. P. 2-13. 


\title{
ANTI-CRISIS FINANCIAL REGULATION OF THE BANKING SYSTEM: DOMESTIC REALITIES AND FOREIGN EXPERIENCE
}

\author{
${ }^{1}$ Maksym Zhytar, ${ }^{2}$ Julia Ananieva \\ ${ }^{1}$ Deputy Director of the Educational and Scientific Institute of Finance, Banking, PhD in Economics, Associate Professor. \\ https://orcid.org/0000-0003-3614-0788. \\ 2Department of Finance named after L. L. Tarangul, PhD in Economics, Associate Professor. https://orcid.org/0000-0003- \\ 0481-5787. \\ 1,2University of the State Fiscal Service of Ukraine. \\ E-mail: ${ }^{1}$ zhytarmaksum@gmail.com, ${ }^{2}$ yuliya_3103@yahoo.com
}

\begin{abstract}
The article substantiates the conceptual approach to the formation of the mechanism for anti-crisis financial regulation of the banking system, which outlines the set of causality and feedback of the elements of the banking system in view of changes in external and internal environments to ensure the development of such a system in the global economic space. The proposed approach identifies the components of the mechanism for anti-crisis financial regulation of the banking system, its features, which are considered and specified in the following elements: a purpose, tasks, subjects, objects, principles, functions, and tools. It has been justified the prospects for adaptation of foreign experience in improving the areas of anti-crisis financial regulation of the banking system by substantiating the main measures and tools, in particular: strengthening control over the activities of banks; focusing banking on financing the real economy; restricting speculative banking operations; separating investment and banking operations; refinancing only those banks that lend to small and medium-sized businesses; stimulating the write-off of problem mortgages; setting a growth limit for large financial corporations; introducing additional taxes and fines for speculative operations of banks and others.
\end{abstract}

Key words: banking system, anti-crisis financial regulation, financial policy, financial stability, crisis, mechanism.

\section{Introduction}

Today, the world community is faced with the challenge of not just anticipating financial crises, but avoiding them or reducing their consequences. It is important to understand the cause of such a problem. The financial system needs not just redecorating that would provide a one-time way out of the crisis, but such a restructuring that would eliminate the crisis, in principle. Improving state regulation of the banking system should be based on this principle. The need to improve the mechanism for anti-crisis financial regulation of the banking system led to the systematization of world experience in the field of study and identification of the main tools used in the banking system to ensure its development and stabilization of the financial condition. The study of foreign experience of anti-crisis financial regulation of the banking system revealed the need for an effective network of supervision and control over the banking system in general and the Central Bank, in particular, in order to reorient the flows of banking resources into the real economy and limit speculative operations. At the present stage of reforming the economy of Ukraine and searching the effective regulatory approaches to economic activity in various areas, it seems appropriate to develop a new methodology for the mechanism for anti-crisis financial regulation of the banking system. This issue is quite relevant for modern Ukrainian statehood due to the need to increase the role of financial regulation of the banking system in rebuilding the national economy. At the same time, it requires resolving the issue of improving the interaction between the National Bank and the Government of Ukraine on the basis of strengthening financial control in order to direct a single public financial policy to innovation and investment development, reduce unemployment and improve the quality of life.

Analysis of recent research and publications. The issues concerning anti-crisis financial regulation of the banking system have been studied by both foreign and domestic scientists and specialists, in particular: S. Adamenko, M. Aleksieienko, I. Blank, T. Bolhar, Dzh. K. Van Khorn, O. Vasylyk, V. Heiets, R. Dzhuchchi, M. Yermoshenko,

V. Zahorodnii, O. Zaruba, I. Kozachenko, L. Lihonenko, A. Moroz, O. Oleinikov, Dzh.F. Sinki, O. Tereshchenko, E. Utkin, R. Shiller and many others. However, despite thorough research by domestic and foreign economists, the issues of adapting the positive world experience of financial regulation of the banking system remain controversial and relevant.

Research results. In the market economy, banks play a key role in supporting the economy of the country and at the same time act as institutions aimed at making a profit and independently taking their own risks. Banks redistribute cash flows from depositors and take the risks associated with intermediary functions. It is the banking system that needs the 
deepest and most balanced financial regulation by the state compared to other sectors of the economy. It is no coincidence that the financial regulation of the banking system in developed economies is one of the most flexible ones. The basis for building domestic state regulation of the banking system in the early 90s of the last century was the experience of the following developed European countries: France, Italy, and Austria. And probably at that time, it was quite a significant step forward in creating an adequate institutional framework that ensured the formation of the banking system of Ukraine.

Today, the world community is faced with the challenge of not just anticipating financial crises, but avoiding them or reducing their consequences. It is important to understand the cause of such a problem. The financial system needs not just redecorating that would provide a one-time way out of the crisis, but such a restructuring that would eliminate the crisis, in principle. Improving state regulation of the banking system should be based on this principle.

The study of foreign experience in relation to approaches to state regulation of the banking system will be conducted in the following areas:

1. analysis of existing world models of the organizational structure of state regulation of the financial sector as a whole and the impact of their use on the functioning of the banking system;

2. study of modern world trends in the degree of control of the executive and legislative authorities of the state over the Central Bank;

3. consideration of the possibility of using the Central Bank as an agent of economic development of the state;

4. highlighting the role of state specialized development banks in ensuring sustainable growth in the productive spheres of the economy and the implementation of innovative projects;

5. clarification of the motives for the implementation of state support for the observance by banking institutions of traditional moral provisions during the conduct of banking.

When choosing the optimal solution in the field of public administration, it is necessary to "develop not one but many models and compare them, which significantly affects the formation of the concepts of public policy, government programs, and plans" [1]. Among the models of the organizational structure of state regulation of the financial sector, which are used in the world are the following: a sector model, a model of mega-regulator, and a model of regulation by tasks [2]. Table. 1 reveals the essence of each of the models of state regulation of the financial sector with a list of countries where they are applied, and advantages and disadvantages of their application.

Table 1. Models of the organizational structure of state regulation the activities of financial institutions in different countries

\begin{tabular}{|c|c|c|c|c|}
\hline Title & Main content & Advantages & Disadvantages & $\begin{array}{l}\text { Country of } \\
\text { application }\end{array}$ \\
\hline 1 & 2 & 3 & 4 & 5 \\
\hline $\begin{array}{l}\text { Sector } \\
\text { Model }\end{array}$ & $\begin{array}{l}\text { Regulation is carried out } \\
\text { by separate authorities } \\
\text { by sectors of the financial } \\
\text { market: banking, non- } \\
\text { banking, securities } \\
\text { market. }\end{array}$ & $\begin{array}{l}\text { Creates the possibility of focused } \\
\text { attention and targeted actions to } \\
\text { promote the development and } \\
\text { implementation of certain tasks } \\
\text { in regulated sectors, considering } \\
\text { their specifics. }\end{array}$ & $\begin{array}{l}\text { There may be } \\
\text { inconsistencies in the } \\
\text { activities of regulatory } \\
\text { authorities on } \\
\text { a common financial } \\
\text { policy. }\end{array}$ & $\begin{array}{l}\text { Belarus, } \\
\text { China, } \\
\text { Luxembourg, } \\
\text { USA, } \\
\text { Finland }\end{array}$ \\
\hline $\begin{array}{l}\text { Model of } \\
\text { Regulation } \\
\text { by Tasks }\end{array}$ & $\begin{array}{l}\text { Regulation is carried out } \\
\text { in two directions - } \\
\text { prudential supervision, ie } \\
\text { preventing financial } \\
\text { institutions from } \\
\text { bankruptcy; regulation of } \\
\text { activities in the financial } \\
\text { sphere in order to } \\
\text { provide reliable } \\
\text { information and ensure } \\
\text { information transparency } \\
\text { of private business. }\end{array}$ & $\begin{array}{l}\text { Saving money on the } \\
\text { maintenance of regulators. It is } \\
\text { aimed at liberalizing the financial } \\
\text { market and is a transition from a } \\
\text { sectoral model to a mega- } \\
\text { regulator model. }\end{array}$ & $\begin{array}{l}\text { Risk of dispersion of } \\
\text { qualified personnel } \\
\text { capable of prudential } \\
\text { supervision. } \\
\text { Weakening of control } \\
\text { functions. }\end{array}$ & $\begin{array}{l}\text { Netherlands, } \\
\text { South Korea, } \\
\text { Sweden, } \\
\text { Japan }\end{array}$ \\
\hline $\begin{array}{l}\text { Model of } \\
\text { Mega- } \\
\text { regulator }\end{array}$ & $\begin{array}{l}\text { Control over any financial } \\
\text { services activity is } \\
\text { exercised by a single } \\
\text { authority that covers the } \\
\text { functions of those } \\
\text { regulatory authorities that } \\
\text { are part of it. }\end{array}$ & $\begin{array}{l}\text { Saving money on the } \\
\text { maintenance of regulators. } \\
\text { Inherent in compact markets, } \\
\text { and the markets characterized by } \\
\text { the universalization of financial } \\
\text { institutions. }\end{array}$ & $\begin{array}{l}\text { Restrictions on } \\
\text { supervisory activities. } \\
\text { Reduction of control } \\
\text { efforts in the context } \\
\text { of each financial } \\
\text { sector. }\end{array}$ & $\begin{array}{l}\text { Great Britain, } \\
\text { Denmark, } \\
\text { Estonia, } \\
\text { lceland, } \\
\text { Kazakhstan, } \\
\text { Latvia } \\
\text { Hungary }\end{array}$ \\
\hline
\end{tabular}


In Ukraine, the financial market is traditionally divided into the market of banking services (the state regulator is the National Bank of Ukraine), the financial services market provides insurance services, credit cooperatives, private pensions, financial leasing (the state regulator is the National Commission for State Regulation of Financial Services Markets), the securities and derivatives market (the state regulator is the National Commission on Securities and Stock Market). Thus, in Ukraine, the sectoral model of the organizational structure of state regulation of the financial sphere is used.

The experience of foreign countries shows that the key to the effective operation of the banking system is not to involve one or another model. Moreover, as Howard Davis, former head of the Financial Services Authority, the UK's financial mega-regulator, said: "The United Kingdom has decided that making a mega-regulator makes sense in our very open markets. But if you look at world practice, you can find a lot of different models of regulation. It is clear that they work well in countries with different types of financial markets and political structures of society. The fact that there are almost as many models of financial market regulation in Europe as there are EU member states says it all. But at the same time, it is absolutely impossible to claim the same model will be efficient for each country" [3].

The financial crisis of 2008 called into question the effectiveness of the single financial regulator. Thus, in Hungary, the activities of the Hungarian Financial Supervisory Authority, which allowed speeding up mass lending in foreign currency have been criticized. It has led to the loss of trust to Hungary in global financial markets, . In this regard, the Hungarian leadership is considering the need to strengthen anti-crisis financial regulation and return the regulatory functions of the banking system to the National Bank of Hungary. For instance, Germany has already stopped separating the functions of the banking system from the Central Bank and restored the functions of the Bundesbank as the sole regulator in the banking market [4]. Despite the fact that since March 2011 in the Russian Federation the regulation of the non-banking financial services market and the securities market has been combined, the regulation of the banking system has traditionally remained with the Central Bank of the Russian Federation [5].

When identifying positive experience in improving the state regulation of the banking system, it is not necessary to focus on the issues of involving one or another model of regulation, granting the Central Bank or any other regulatory institution the right to be the main regulator. Changing the current sectoral model is not expedient for Ukraine and it is an unjustified waste of time, increasing instability both in the banking sector and in the economy as a whole. It is more important to make correct conclusions about the mistakes made by different countries and to adopt the peculiarities of banking regulation of those countries that have demonstrated stable socio-economic development for decades and which during the crisis demonstrated the strength of their own banking system. Therefore, in current conditions, it is important for Ukraine to adhere to the sectoral model of the regulation when the regulation of the banking system is not mixed with the regulation of other sectors of the financial sector.

There are two most common forms of the organizational structure of the Central Bank control in the world, which are determined by the characteristics of the functions they perform [6]:

Form I - the Central Bank conducts monetary policy, which is a part of the tools that the government has to regulate the economy. At the same time, monetary policy is related to budget, structural, innovation, investment policies, and is used to implement economic and social tasks of the government (Germany, Great Britain, China, Japan, and Canada);

Form II - the Central Bank conducts monetary policy using instruments that do not depend on the government. The main purpose of the Central Bank in such conditions is only to maintain price stability (Argentina, Latvia, Poland, the Russian Federation, Greece).

According to the Constitution of Ukraine, ensuring the stability of the national unit is the main function of the Central Bank of the State - the National Bank of Ukraine. The NBU Council develops the basic principles of monetary policy and monitors its implementation [3]. According to Art. 6 of the Law of Ukraine "On the National Bank of Ukraine" the NBU when exercising its primary function, namely, ensuring the stability of the monetary unit, should consider the priority of achieving and maintaining price stability in the country. The National Bank should contribute to the stability of the banking system. In addition, within the limits of its authority, it must promote sustainability in the economic growth and economic policy of the Cabinet of Ministers of Ukraine. In addition, the NBU performs 22 additional functions, which are fixed in Art. 7 of the same law [2]. The relations between the NBU and the Government of Ukraine are based on the principles of the autonomy of the former. The NBU is not responsible for the obligations of public authorities, second-tier banks, and the latter are not responsible for the obligations of the NBU [3]. Based on this, it can be argued that the model of building the organization of the banking system in Ukraine is closer to the second, under which the banking system can not be actively involved in solving socio-economic problems of the country.

The study of foreign experience in the financial regulation of the banking system has revealed the need for an effective network of supervision and control over the banking system in general and the Central Bank, in particular, in order to reorient the flows of banking resources into the real economy and limit speculative operations. Thus, it has been generalized the peculiarities of application of conceptual and methodological approaches to financial regulation of the banking sector in the world: state financial support of foreign financial institutions, nationalization of banks, joining of small troubled banks to large financial corporations, use of business continuity regulation mechanism, guarantee of bank deposits and others. Reforming the current financial regulation of the banking system involves both the formation of a system of effective influence on the activities of banking institutions and the identification of the factors that contribute to more efficient functioning of the banking system and its compliance with the interests of the national economy. 
Operating in conditions of perfect competition is an ideal state for the market, and for its achievement, certain efforts of anti-crisis financial regulation should be directed. In economic theory, a perfect market is characterized by the fact that the market is completely transparent, and prices are known to all participants; a market is competitive when all its participants are independent and have equal access to it; market participants act rationally. A perfect market is able to perform perfectly all the functions of capital and is the most optimal model in economic theory. However, in practice, each of the world's known economies is not perfect as a result of five classic causes of market imperfection: externalities, effect of indivisibility, asymmetric information, adaptation deficiencies, and irrational behavior of market participants [3].

Anti-crisis financial regulation of the banking system should be considered as a set of measures to neutralize these market failures and as a process of financial support for the functioning and development of an integrated economic system through planning indicators, monitoring their compliance, financing of strategically important entities, and management of state property.

During the evolution of the banking system of any country with a market economy, we can distinguish the influence of two different trends: desire of the state to ensure stability of the banking system and assign to the Central Bank (or similar authority) functions relevant to state policy; tendency of the participants of the sector, represented by the owners of financial intermediaries, to the greatest economic efficiency [4-5].

The mechanism for anti-crisis financial regulation of the banking system is an important component of financial regulation and, unlike other areas of economic regulation, significantly increases the responsibility for regression or development of each sector of the economy separately and the national economy as a whole. First of all, this is due to the multifunctional purpose of the banking system, primarily the National Bank, which is responsible for the formation and coordination of monetary or money-credit policy. The monetary or money-credit policy is the process of ensuring the stability of the national unit and regulating the money supply to stabilize the economy and sustainable banking, functioning institutions, ensuring the effective functioning and development of the money market. In addition, the banking system can promote the implementation of state policy on the protection and development of strategic sectors of the domestic economy, and implementation of innovative projects.

The mechanism for anti-crisis financial regulation of the banking system involves certain methods of influence and tools for implementing regulatory action. According to the forms of influence on market participants, the methods of the mechanism of financial regulation of the banking system are divided into two groups:

1) methods of direct influence (administrative): various limits, centrally set prices, restrictions, fines, permits, licenses, quotas, etc., as well as methods based on the use of the budget as a source of subsidies, limit lending for individual banks; direct regulation of interest rates, limits on the volume or value of loans granted to individual industries;

2) methods of indirect (intermediary or market) influence contain methods that regulate the behavior of market participants not directly, but through the creation of a certain environment for its activities, cause different kinds of behavior: influence on the money supply by creating certain conditions in the money market and capital market, tax regulation, regulation through the policy of accelerated depreciation, methods of stimulating competition, etc.

The tools for implementing the regulatory impact of the mechanism for anti-crisis financial regulation of the banking system can be divided according to the types of levers of regulation, which, of course, are closely interrelated: monetary relations; banking economic standards; entry and exit of banks in the market of banking services.

The instruments for regulating monetary relations include reserve requirements, interest rates on Central Bank operations, open market operations, bank refinancing, currency regulation, setting benchmarks for money supply growth, direct quantitative restrictions.

The tools for regulating the entry and exit of banks in the market of banking services include: - regulation of access to the banking system. This means, firstly, the ability to define certain requirements and conditions that are mandatory for obtaining a license to conduct banking activities, and, secondly, to supervise compliance with these requirements and conditions; - regular receipt of reports from banks and inspections in banks; - application of coercive measures against troubled banks, including a ban on declaring and paying dividends, imposing fines, etc.; - taking insolvent banks under special control, appointing a temporary administration to such banks, suspending their activities, organizing the reorganization and liquidation of banks [6].

The mechanism for anti-crisis financial regulation of the banking system is provided by a number of functions, which are understood as specific areas of activity. The purpose of the target functions is to focus on the goals set for the mechanism for financial regulation of the banking system, which should cover both the banking system and the economic system of the country as a whole.

The mechanism for anti-crisis financial regulation of the banking system should be aimed at performing the following functions: banking regulation, banking supervision, state banking control. The first step in building such a mechanism is to determine the purpose of the system. Given the content of the definition of "anti-crisis financial regulation" from the standpoint of its components, which correlate with the definition of "financial stability", the main components of the purpose should be identified as follows: ensuring stable and secure operation of the banking system (banks); prevention of destabilizing processes (trends) in the banking sector; restrictions on banking activity and banking operations; promoting the economic development of the country [7-8].

A solid prerequisite for achieving this purpose is the implementation of tasks that are the basis of financial regulation. Based on the results of generalization of the views of leading scientists on the tasks of financial regulation in the context of 
financial stability of the banking system and consideration of its property, namely, emergence, we have distinguished two groups of tasks: 1) forming the transparent policy of the NBU to ensure financial stability; creating competitive environment in the banking sector; maintaining required level of standards and professionalism in the banking sector; preventing the spread of systemic risks in the banking system and equalizing financial disparities that are inherent to it, etc .; 2) increasing the level of capitalization of banks; ensuring the liquidity of banking institutions; balancing the quality of assets; strengthening the interdependence and sensitivity of the structure of banking institutions to changes in the optimal values of mandatory standards, in particular, and the transformation of banking legislation in general.

Completion of the tasks and achievement of the purpose of the mechanism for anti-crisis financial regulation of the banking system is based on observance of the corresponding principles and performance of necessary functions. The mechanism for financial regulation of the banking system is based on general (adequacy, openness, responsibility, sufficiency, efficiency, legality, independence, consistency, transparency and market discipline, systematicity, fairness, duration and predictability, consistency of interests and priorities, purposefulness) and specific principles (level of acquisition, approach to accounting for financial investments of owners, principles of Basel I, Basel II, Basel III).

It should be noted that the peculiarity of such a system is determined levels of financial stability and a coordinated combination of monetary policy instruments of the NBU, existing and promising instruments for macro- and microprudential regulation. It allows forming a comprehensive approach to ensuring financial stability and it should be taken into account during its monitoring.

\section{Conclusions}

Critical analysis and implementation of foreign experience expand the list of aspects of comparative analysis, allows a more reasonable determination of the near future prospects of the banking system of the national economy. Along with building a safe and sound banking system, it should be assumed that it must direct capital to finance businesses and create jobs in the context of providing quality services to their operation and development. In the developed countries, financing of the real sector of the economy is the object of close attention and support from the state, which provides stimulation of innovation, investment, and business activity, is a guarantor of socio-economic development and economic security of the country.

The results of the study of the practice of financial regulation of the banking system in economically developed countries have become the basis for the formation of a set of recommendations for improving such regulation in Ukraine, in particular: strengthening state supervision of the banking system aimed at preventing banking crises; modernization of the procedure for guaranteeing bank deposits; creation of an effective infrastructure for supervision and control over the banking system, etc. It has been established that developed countries introduce a mechanism for business continuity regulation to ensure the development of the banking system. The key tool of such a mechanism is the plan of business continuity of banking institutions. Taking into account the practical achievements of the world's leading banks, the main directions of reducing the costs of their activities have been systematized, including reducing operating costs, reducing the network of branches and payroll, limiting the marketing budget, etc.

It has been developed conceptual provisions for the formation of the mechanism for anti-crisis financial regulation of the banking system, which create a holistic view of the possibility of rebooting the domestic banking system, solving existing internal financial problems and its transformation in accordance with the European-oriented vector of the national economy. Such a mechanism is implemented on the basis of a dualistic approach to the redistribution of tasks and instruments of influence between state regulators and banking self-regulatory organizations.

\section{REFERENCES}

1. Baranovskyi O.I. (2014) Filosofiia bezpeky: monohrafiia: u 2-kh t. T. 2. [Philosophy of security: monograph: in 2 vols. Vol. 2.]. Bezpeka finansovykh instytutiv - Security of financial institutions.. K.: UBS NBU, 715 p. [in Ukrainian].

2. Dmytrova O.S. (2015) Klasyfikatsiia zahroz ta ryzykiv ekonomichnoi bezpeky banku [Classification of threats and risks of economic security of the bank]. Efektyvna ekonomika - Efficient economy. № 11. P.126-132 [in Ukrainian].

3. Kokovikhina O.O., Oliinyk A.Yu. (2015) Identyfikatsiia zahroz finansovii bezpetsi banku [Identification of threats to the bank's financial security.]. Visnyk ekonomiky transportu i promyslovosti - Bulletin of Transport Economics and Industry. № 50. P. 329-333 [in Ukrainian].

4. Lisniak A.Ye. (2017) Chynnyky finansovoi bezpeky bankiv [Factors of financial security of banks]. Visnyk universytetu bankivskoi spravy - Bulletin of the University of Banking. № 3(30). URL: http://visnuk.ubsnbu.edu.ua/article/ view/124469 [in Ukrainian].

5. Novyi biznes - New business. URL: https://biz.nv.ua/ukr/experts/ saygun / chim-horosha-likvidatsija-bankiv485347 [in Ukrainian].

6. Rudenko O., Dyvnych H. (2019) Conceptual comprehension of strategies for ensuring social stability in the interests of the citizens and the safety of the state. Fundamental and Applied Researches in Practice of Leading Scientific Schools, 31(1), pp.173-177. [in Canada] 
7. Kriuchko L.S. (2015) Osoblyvosti upravlinnia vitchyznianymy bankamy [Features of management of domestic banks]. Efektyvna ekonomika - Efficient economy. №4. P.86-92

8. Shestakovska, T., Radchenko, O., Streltsov, V., Radchenko, O., Chernov, S. (2020). Ensuring environmental safety of the food industry: Influence on leadership positions in the economy. Ukrainian Journal of Ecology, 10(3), 19-23. [in Ukrainian] 


\title{
FOR A PROPER UNDERSTANDING OF THE ESSENCE AND INTRINSICALLY OF CREATIVE MANAGEMENT
}

\author{
Irma Baratashvili \\ Caucasus International University, Dean of the Faculty of Business, PhD in Business Administration Associate Professor. \\ https://orcid.org/0000-0002-7723-6009 \\ Email: nino.makharashvili@cia.edu.ge
}

\begin{abstract}
The current global processes at the modern stage of social development require the formation of new approaches to socio-economic development. In the complex of new approaches, the means of promoting development is to increase the quality and efficiency of economic-financial management.

Modern governance often calls for the use of well-proven, innovative management in the governance process, and now economics calls for the use of elements of creative management that involve the use of unconventional methods and techniques in the management process. After all, management in the general and general sense is a conscious human activity to achieve the goals set for the organization of joint labour. Management needs to be understood as the ability to achieve goals by using other people's labour, intellect, and behavioral motives.

There are many types of activities and facilities in enterprises and organizations (e.g. production, material and technical supply, finance, marketing, personnel, sale of finished products, etc.).

We must recognize that today, in the conditions of an innovative economy, creative management is the most important strategic direction for the development of management science. Creative management reflects a specific aspect of modern industry and enterprise management in the context of accelerating the shift in technological innovation.

Today there is a sharp increase in demand for inventive management and managers who possess the ability to venerate quickly to make non-standard and original ideas realization, solve problem situations quickly and efficiently

The motto of the master of modern creative management: "I know for sure that the impossible is possible" such a manager today must virtuously master the methods, rules and techniques of non-standard, original management decisions.

We, of course, cannot deny or neglect the innovative management (management of innovation, the introduction of innovations), which implements such innovative management functions as the organization of scientific research processes, the organization of fundamental processes, the organization and organization of projects. But in the modern era - in the conditions of information and innovative economy, fundamentally new problems and tasks are emerging, which are related to the new search, uncertainty and uncertainty, non-copied approaches to their solution, as well as nonstandard, emergency and crises.

It is this circumstance and condition that determines the necessity of active use of creative management in enterprise management.

Creative management is based on creative thinking, creative (intellectual) skills, abilities and thinking. In a broad sense, creative thinking is defined as the thinking that results and that leads to innovative ideas and discoveries, to fundamentally new solutions to problematic situations.

Creativity in the field of economics usually refers to work aimed at creating fundamentally new goods.

Adaptation to the field of governance in creative thinking, Implies the ability to develop a unique, non-standard management solutions, search for non-standard innovative ideas

Human creative (innovative) abilities to create original, non-standard and different ideas, including in management, are realized by his convergent and divergent ability the ability to think lethally.

The main difference between creative (innovative) thinking and logical (template) thinking is that logic plays only an auxiliary role in the process of creative thinking. When in logical thinking, it belongs to the leading role as far as it controls the mind.

Characteristics of creativity are highlighted by a number of authors. In particular, courage, speed, agility, originality, thoughtfulness, assimilation, transformability, unity (connection of elements, connectivity), metaphor and so on.

And yet, the main distinguishing feature of creativity is the ability of a person to discover new ways and means of solving problematic problems, skills - to break the rules of thinking and stereotypes of means; In other words, the forefront of the description of "creativity" is a sign of non-standard thinking, the ability to look at existing and known realities in a new way. Creative management is the process of managing the creative (innovative) potential of an organization, enterprise and others, its, ie. For the effective development of a given organization, a legal entity. The special urgency of the collapse of creative management in the management system of enterprises and organizations is determined by the acceleration of the generational change of innovations, in the absence of preconceived notions, uncertainty. At the same time, there is a constant need to develop and implement non-traditional management decisions due to emergencies and crises.
\end{abstract}


The objective guidelines that define the emergence of creative management are:

- In the activities of enterprises in various fields of organizations constantly, problems arising that are difficult to solve

- Fundamentally new tasks that arise in conditions of uncertainty, when the internal and external circumstances of enterprises are indistinct;

- Innovative advantages are quickly replicated by competitors. As a result, to maintain its competitive predominance, the enterprise (company), must systematically improve and re-produce new, original products and effective management solutions;

- $\quad$ Constant changes in all spheres of society, regularly emerging emergencies and crises that require and need the search for non-traditional solutions, substantiation of effective ways of enterprise development;

- $\quad$ Lack of decision-making and implementation or lack of necessary (known) mechanisms, tools and methods, as well as the impact of several other circumstances.

The goal of creative management is to activate the process of generating innovative ideas and to develop previously unknown, non-standard, original management decisions by management staff.

There are general and specific tasks of creative management.

General tasks are development and implementation:

- $\quad$ The original strategy of the enterprise, company development;

- $\quad$-Original, innovative product concepts;

- $\quad$ In the conditions of non-standard operative management decisions - uncertainty, emergency and crises;

- Original management news;

- $\quad$-Creative staff training programs, etc.

Specific tasks of creative management as a tool for solving non-standard management tasks should be:

- $\quad$ Find and justify the right solution strategy from the many possible options, alternatives to problem-solving strategies;

- $\quad$-Comparative analysis of alternative solutions based on different evaluation criteria

- Substantiation of mechanisms, tools and methods for the implementation of non-standard strategies based on the use of the potential of the management staff;

- Achieving the effectiveness of criteria and indicators of targets and alternative governance decisions. Based on adaptive control of the system and making decisions to adjust actions in real-time.

Since we consider creative management as a type of managerial activity, it is necessary to note that it is characterized by several general and specific principles. Such principles provide for the objective, common and solid, constantly evolving connections between creative management processes, events, and objects.

Failure to follow the general and specific principles of creative management will eventually lead to contradictions, conflicts, disproportions and imbalances in the management system of the organization (company, enterprise).

Thus, creative management, as a type of managerial activity scientifically substantiated management tool, is used both for strategic development purposes, as well as to overcome constantly emerging emergencies and crises; Especially when it is necessary to find and realize fundamentally new ways of survival, moving forward, achieving enterprise competitiveness in the market.

In its essence, creative management is a creative-innovative activity to manage the creative process of developing and selling innovations under the original management. It is an activity for presenting non-standard, original ideas and their practical realization and commercialization.

Creative management focuses on the development and implementation of innovations in governance, planning, organization, motivation, control, communications and management decision-making technologies; In other words, these are organizational-managerial innovations.

\section{REFERENCE}

1. Jane Henry, Creative Management, Sage Publications Ltd, London, 1991

2. Michael Dobson, Creative Project Management, McGraw-Hill Education; 1st edition (August 18, 2010) 


\section{GROUP OF REVIEWERS}

Abbas İsmayılov

Azerbaijan State Agricultural University. Associate Professor. PhD in Biology Science. (Azerbaijan).

Aleksander Kuczabski

Institute of Geography of Uniwersytet Gdański. Department of Regional Development Geography. Doctor in Public Administration Science. Associate Professor. (Poland).

Alla Kasych

Kyiv National University of Technologies and Design. Doctor in Economics. Professor. (Ukraine).

Aytekin Hasanova

Azerbaijan Medical University. I Preventive Medicine Faculty. Deputy of Dean. PhD in Medical Biology. (Azerbaijan).

Dariusz Pawliszczy

Gromadka Commune Office, Doctor of Philosophy. (Poland)

Davit Jalagonia

Sokhumi State University. Adviser to the Rector. Professor. PhD in Economics. (Georgia).

Dmytro Nelipa

Taras Shevchenko National University of Kyiv. Doctor in Political Science. Professor. (Ukraine).

Elchin Suleymanov

Baku Engineering University. Associate Professor. Department of Finance. PhD in Economy. (Azerbaijan). Irma Baratashvili

Caucasus International University. Dean of the Faculty of Business. PhD in Business Administration.

Professor. (Georgia).

Marine Khubua

Sokhumi State University. PhD in Economics. Associate Professor. (Georgia).

Maksym Zhytar

University of the State Fiscal Service of Ukraine. PhD in Economics. Associate Professor. (Ukraine).

Marcin Kesy

University of Economy in Bydgoszczy, Doctor of Economic Sciences. (Poland)

Myroslav Kelemen

Technical University of Košice, Slovakia Dr.h.c. prof. Ing., DrSc. MBA, LL.M., Brigadier General ret., (Slovakia)

Oksana Zhukova

V.N.Karazin Kharkiv National University. Doctor in Pedagogy Science. Associate Professor. (Ukraine).

Peter Jakubek

Quaestor of DTI University, Doctor in Economics. Associate Professor. Dubnica and Vahom. (Slovakia).

Roman Hrmo

DTI University Dubnica nad Váhom, Slovakia, Assoc.prof. Paed Dr. Ing., PhD., MBA, ING-PAED IGIP, (Slovakia)

Tetiana Shestakovska

Chernihiv Polytechnic National University. Doctor in Public Administration Science. (Ukraine).

Vasil Kikutadze

Tbilisi State University. PhD in Economics. Dean of Faculty of Business and Engineering. East European University; Associate Professor. (Georgia).

Victor Melnyk

Kyiv National Economic University named after V.Hetman. Doctor in Economics. Professor. (Ukraine). 


\section{AIMS AND SCOPE}

ICRET MTÜ The Baltic Scientific Journals publishes peer-reviewed, original research and review articles in an open access format. Accepted articles span the full extent of the social and behavioral sciences and the humanities.

ICRET MTÜ The Baltic Scientific Journals seeks to be the world's premier open access outlet for academic research. As such, unlike traditional journals, ICRET MTÜ The Baltic Scientific Journals does not limit content due to page budgets or thematic significance. Rather, ICRET MTÜ The Baltic Scientific Journals evaluates the scientific and research methods of each article for validity and accepts articles solely on the basis of the research. Likewise, by not restricting papers to a narrow discipline, ICRET MTÜ The Baltic Scientific Journals facilitates the discovery of the connections between papers, whether within or between disciplines.

ICRET MTÜ The Baltic Scientific Journals offers authors quick review and decision times; a continuous-publication format; and global distribution for their research via ICRET MTÜ The Baltic Scientific Journals Online. All articles are professionally copyedited and typeset to ensure quality.

Those who should submit to ICRET MTÜ The Baltic Scientific Journals include:

Authors who want their articles to receive quality reviews and efficient production, ensuring the quickest publication time.

Authors who want their articles to receive free, broad, and global distribution on a powerful, highly discoverable publishing platform.

Authors who want their articles branded and marketed by a world-leading social science publisher.

Authors who want or need their articles to be open access because of university or government mandates.

The Baltic Scientific Journals

ISSN: 2613-5817; E-ISSN: 2613-5825; UDC: 0 (0.034);

DOI PREFIX: 10.36962/PIRETC

Proceeding of The International Research Education \& Training Center.

http://sc-media.org/piretc/

ISSN: 2674-4562, E-ISSN: 2674-4597, UDC: 620.9 (051) (0.034);

DOI PREFIX: 10.36962/ENECO

Proceedings of Energy Economic Research Center. ENECO

http://sc-media.org/eneco/

ISSN: 1609-1620, E-ISSN: 2674-5224; UDC: 62 (051) (0.034);

DOI PREFIX: 10.36962/PAHTEI

Proceedings of Azerbaijan High Technical Educational Institutions. PAHTEI

http://sc-media.org/pahtei/

ISSN: 2663-8770, E-ISSN: 2733-2055; UDC:

DOI PREFIX: 10.36962/ETM

ETM Equipment, Technologies, Materials

http://sc-media.org/etm/

ISSN: 2733-2713; E-ISSN: 2733-2721; UDC:

DOI PREFIX: 10.36962/SWD

SOCIO WORLD-SOCIAL RESEARCH \& BEHAVIORAL SCIENCES

http://sc-media.org/swd/ 
Topics of journal

A: General Economics and Teaching

$F$ : International Economics

G: Financial Economics

$\mathrm{H}$ : Public Economics

I: Health, Education, and Welfare

$\mathrm{J}$ : Labor and Demographic Economics

$\mathrm{K}$ : Law and Economics

L: Industrial Organization

M: Business Administration and Business Economics

Marketing

Accounting

Personnel Economics

$\mathrm{N}$ : Economic History

O: Economic Development, Innovation, Technological Change, and Growth

P: Economic Systems

Q: Agricultural and Natural Resource Economics

Environmental and Ecological Economics

R: Urban, Rural, Regional, Real Estate, and Transportation Economics

Z3: Tourism Economics 
NGO International Center for Research, Education \& Training (Estonia, Tallinn) is publishing scientific papers of scientists on Website and in Referred Journals with subjects which are mentioned below:

(C) The Baltic Scientific Journals

ISSN: 2613-5817; E-ISSN: 2613-5825; UDC: 0 (0.034);

DOI PREFIX: $10.36962 / P I R E T C$

Proceeding of The International Research Education \& Training Center.

http://sc-media.org/piretc/

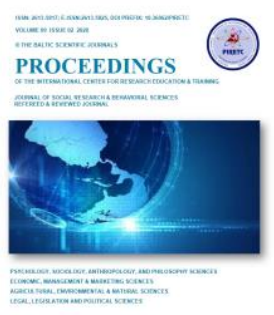

ISSN: 2674-4562, E-ISSN: 2674-4597, UDC: 620.9 (051) (0.034);

DOI PREFIX: 10.36962/ENECO

Proceedings of Energy Economic Research Center. ENECO

http://sc-media.org/eneco/

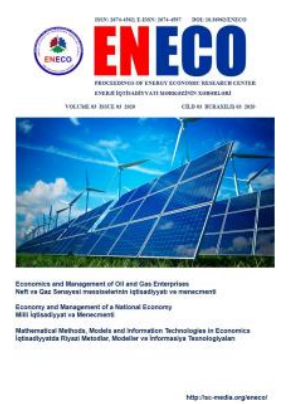

ISSN: 1609-1620, E-ISSN: 2674-5224; UDC: 62 (051) (0.034);

DOI PREFIX: 10.36962/PAHTEI

Proceedings of Azerbaijan High Technical Educational Institutions. PAHTEI

http://sc-media.org/pahtei/

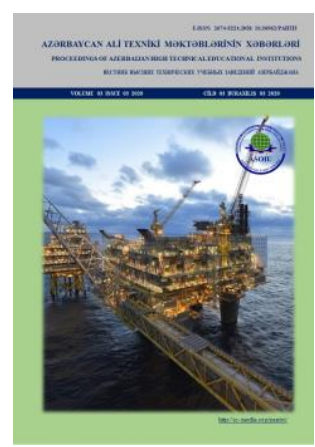


ISSN: 2663-8770, E-ISSN: 2733-2055; UDC:

DOI PREFIX: 10.36962/ETM

ETM Equipment, Technologies, Materials

http://sc-media.org/etm/

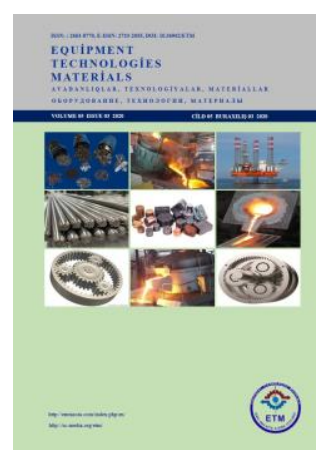

ISSN: 2733-2713; E-ISSN: 2733-2721; UDC:

DOI PREFIX: 10.36962/SWD

SOCIO WORLD-SOCIAL RESEARCH \& BEHAVIORAL SCIENCES

http://sc-media.org/swd/

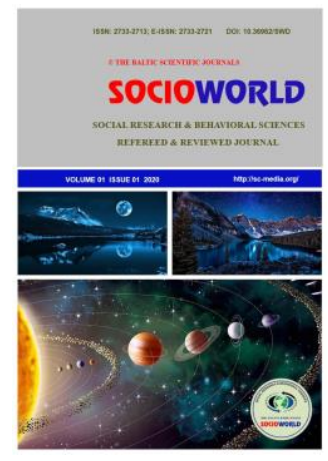

Society of Azerbaijanis living in Georgia. NGO. (Georgia, Tbilisi) is publishing scientific papers of scientists on Website and in Referred Journals with subjects which are mentioned below:

(C) Southern Caucasus Scientific Journals

ISSN: 1987-6521, E-ISSN: 2346-7541; UDC: 551.46(0510.4)

DOI PREFIX: 10.36962/GBSSJAR, IF-1.05

Gulustan-Black Sea Scientific Journal of Academic Research http://sc-media.org/gulustan-bssjar/

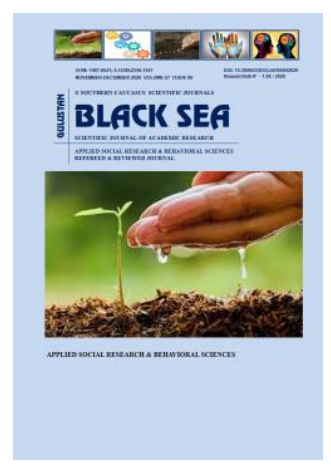


ISSN: 2346-8068; E-ISSN: 2346-8181;

DOI PREFIX: 10.36962/ALISJMSC

Ambiance in Life-International Scientific Journal in Medicine of Southern Caucasus.

http://sc-media.org/ambiance-in-life-isjmsc/

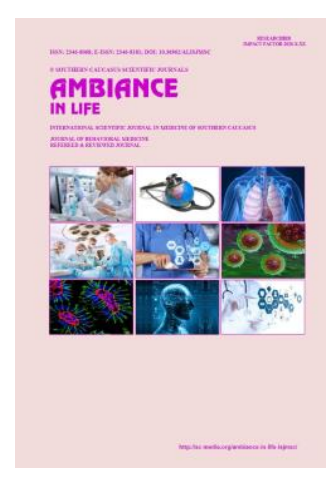

Representation of the International Diaspora Center of Azerbaijan in Georgia. NGO. (Georgia Tbilisi) is publishing scientific papers of scientists on Website and in Referred Journals with subjects which are mentioned below:

\section{(C) Southern Caucasus Scientific Journals}

ISSN: 2298-0946, E-ISSN: 1987-6114; UDC: 3/k-144

DOI PREFIX: 10.36962/CESAJSC

The Caucasus-Economic and Social Analysis Journal of Southern Caucasus

http://sc-media.org/the-caucasus-sjarsc/

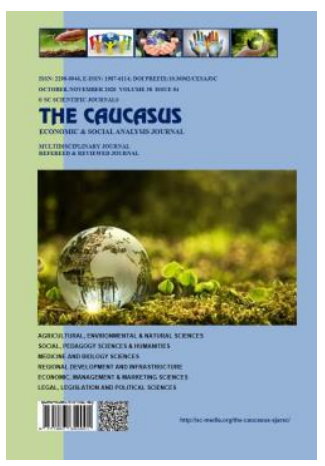




\section{JOURNAL INDEXING}

\section{乎ESTER}
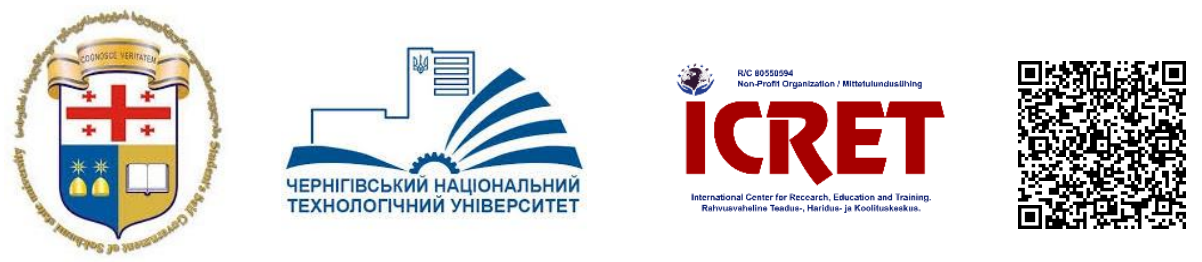

\section{(C) THE BALTIC SCIENTIFIC JOURNALS}

\section{ISSN: 2733-2713; E-ISSN: 2733-2721; DOI: 10.36962/SWD}

(C)Publisher: Sokhumi State University. R/C 405282260.

Registered address: 26, Politkovskaya street, 0186, Tbilisi, Georgia.

(C) Publisher: Chernihiv Polytechnic National University. RIC 054607925261

Registered address: 95, Shevchenko street, 14035, Chernihiv, Ukraine.

CPublisher: All Ukrainian Institute of Eurasian Research And Eastern Science. R/C 39783993

Registered address: 3B, Petra Hryhorenka Avenue, office 111, Kyiv, 02068, Ukraine.

(CPublisher: NGO International Center for Research, Education \& Training.

MTÜ Rahvusvaheline Teadus-, Haridus- ja Koolituskeskus.

Registered address: Narva mnt 5, 10117 Tallinn, Estonia. 
(C) THE BALTIC SCIENTIFIC JOURNALS

\section{SOCIOWORLD}

SOCIAL RESEARCH \& BEHAVIORAL SCIENCES

REFEREED \& REVIEWED JOURNAL

\section{VOLUME 01 ISSUE 012020}

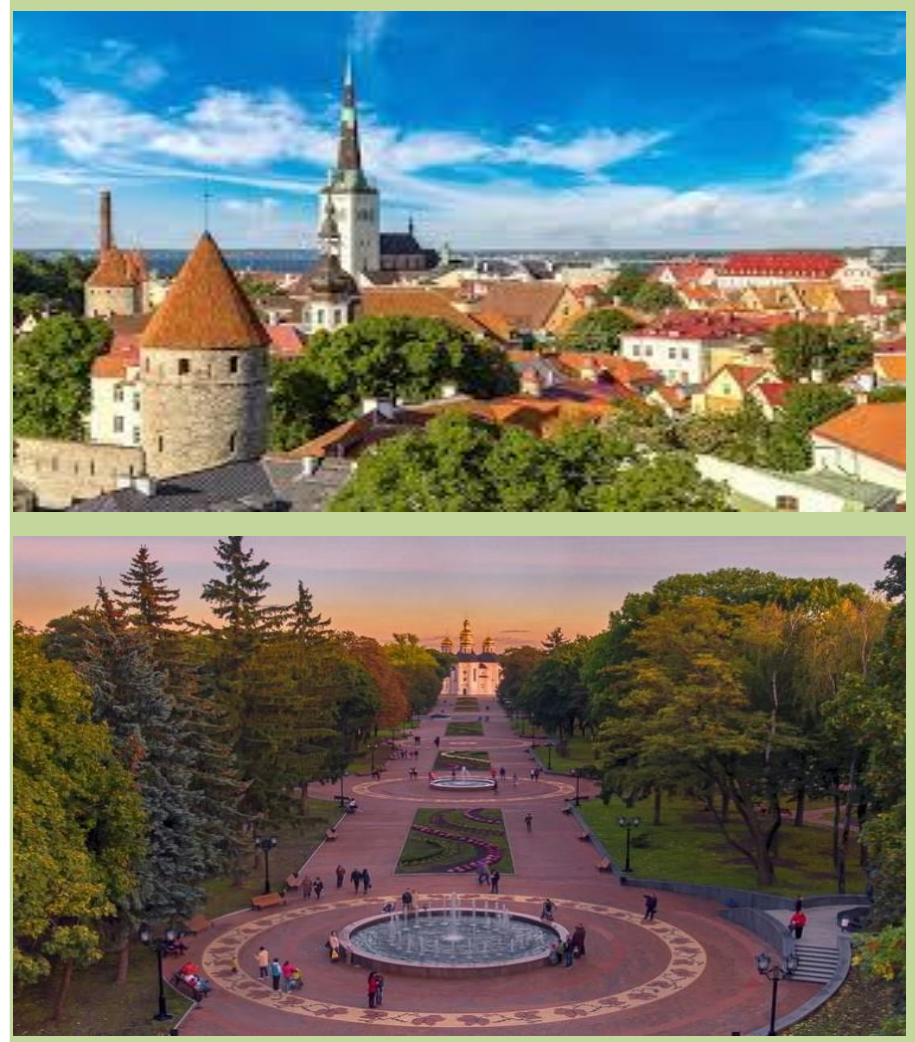

http://sc-media.org/
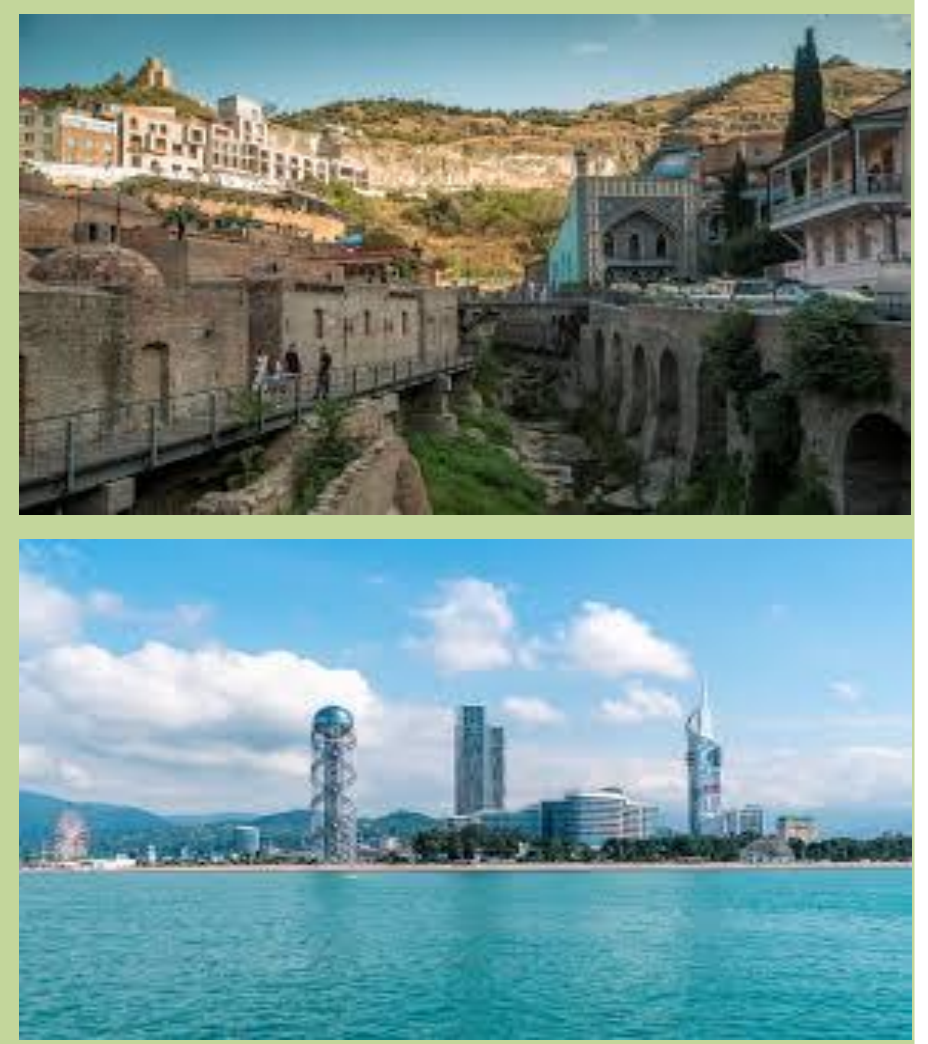

3.

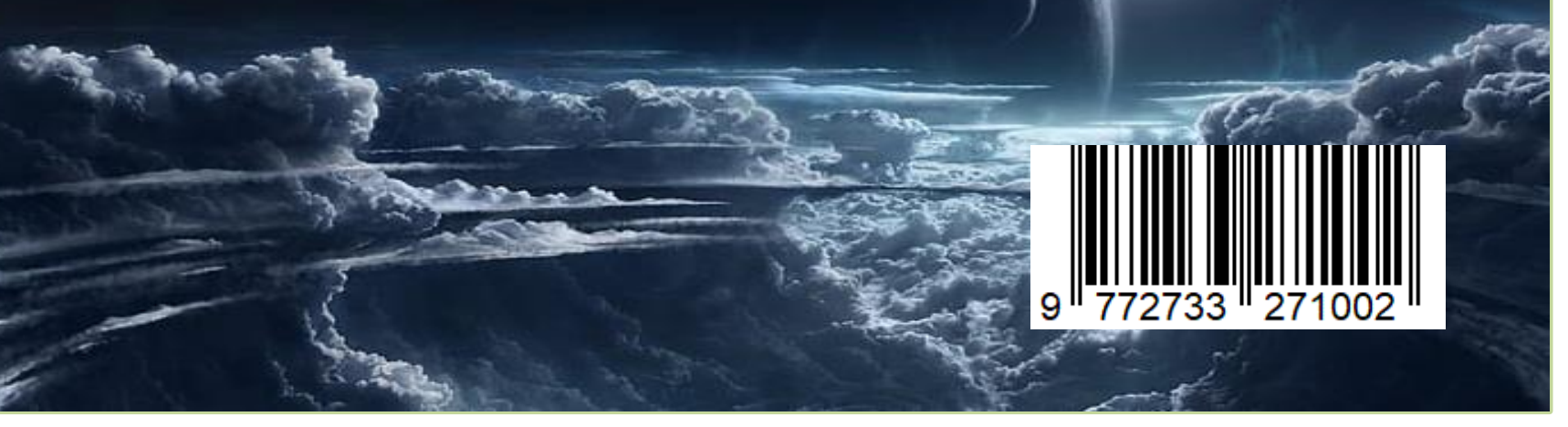

